\title{
ESTUDO COMPARATIVO DOS EFEITOS DA UTILIZAÇÃO DE DOIS TIPOS DE COMANDOS VERBAIS DIFERENTES NO TREINAMENTO DE ALONGAMENTO MUSCULAR
}

Maria Silvia Pardo 


\section{PROGRAMA DE EXERCÍCIOS DE ALONGAMENTO COM ORDEM CRESCENTE DE DIFICULDADE}


PROGRAMA PARA DOZE SEMANAS DE TREINAMENTO,

DUAS VEZES POR SEMANA, UMA HORA POR SESSÃO 


\section{CATORZE POSTURAS POR SESSÃO \\ COM TRÊS REPETIÇÕES}




\section{PRIMEIRA SEMANA}




$$
1
$$




$$
1
$$




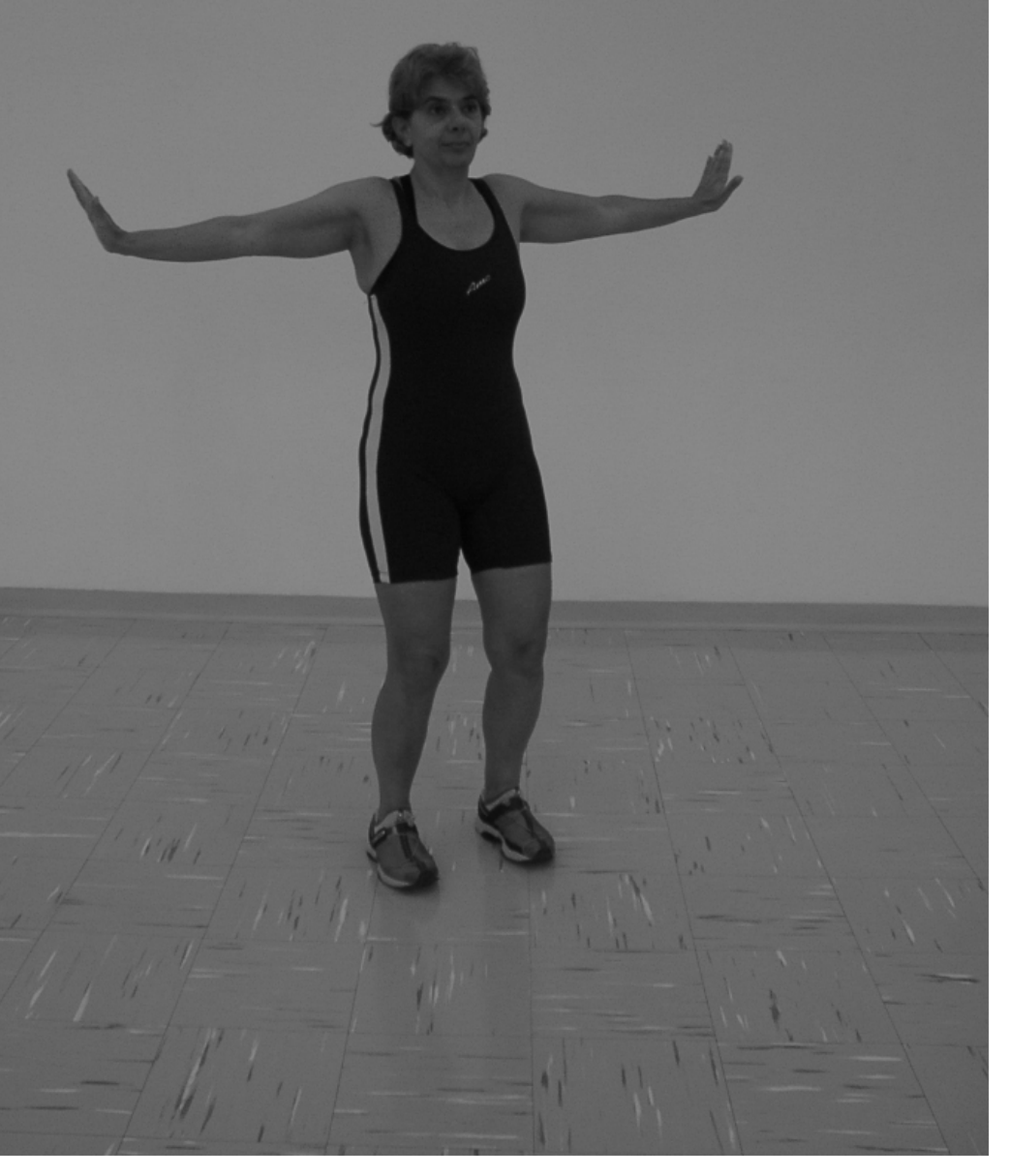




$$
1
$$


<smiles>OCC1CCCCC1</smiles> 



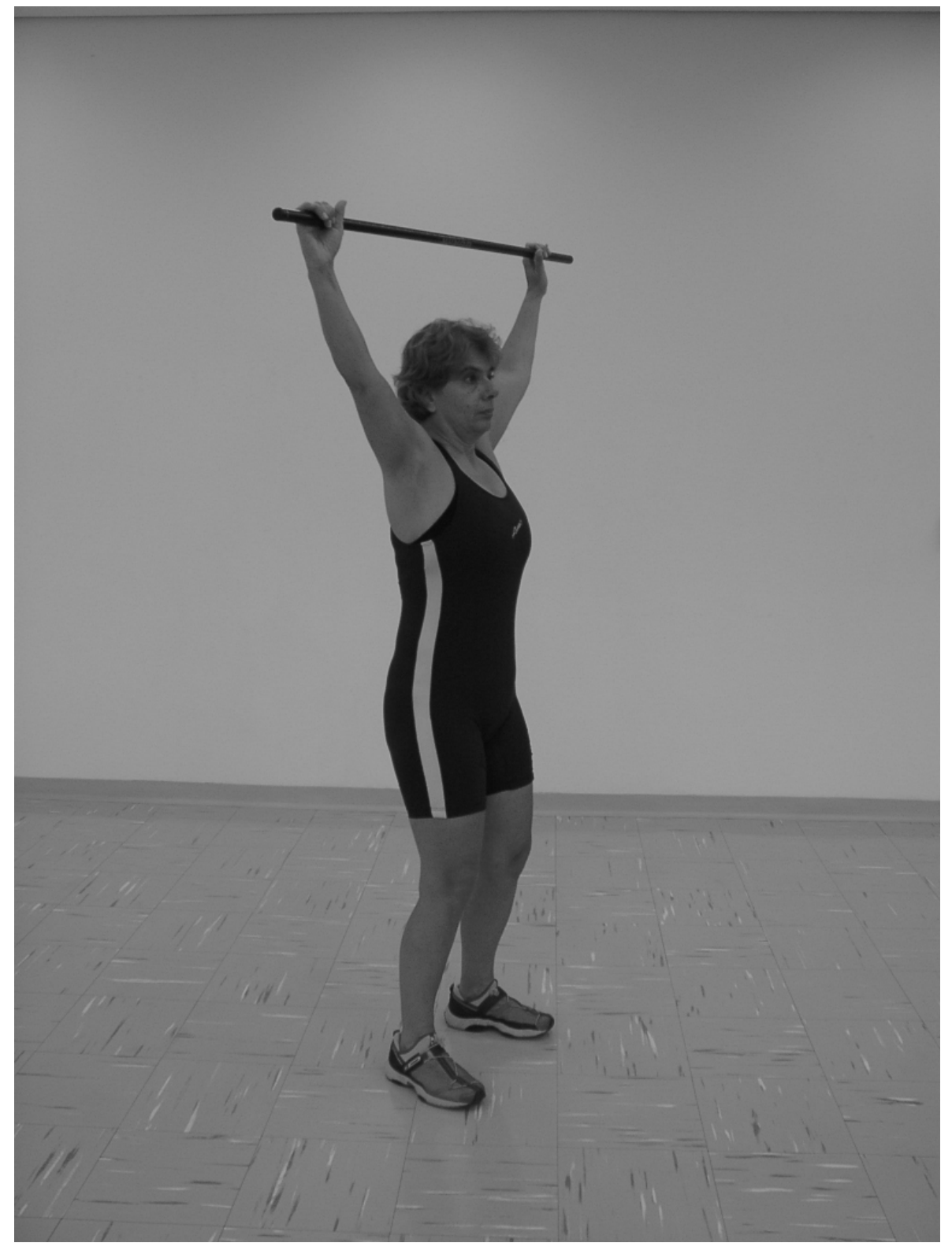




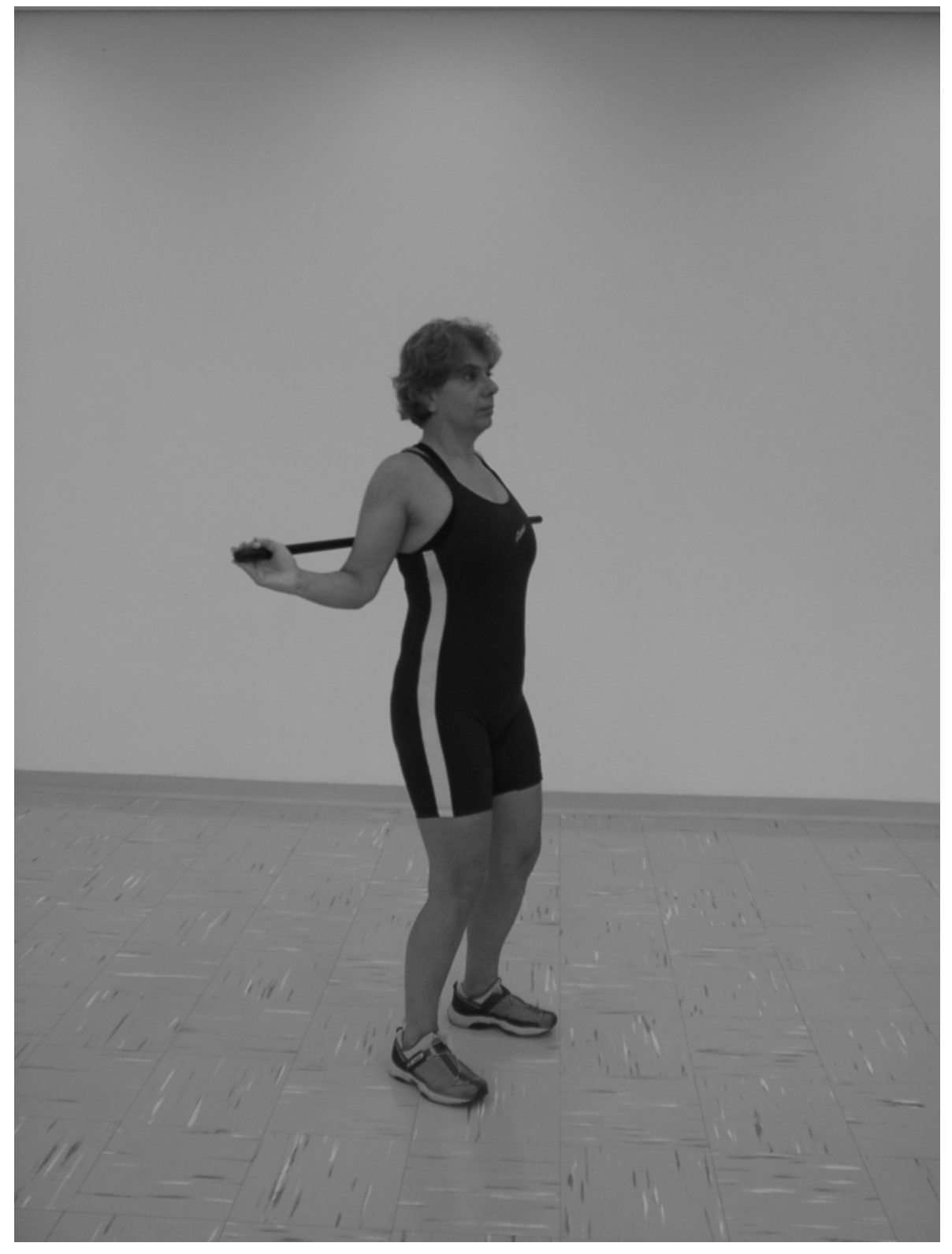




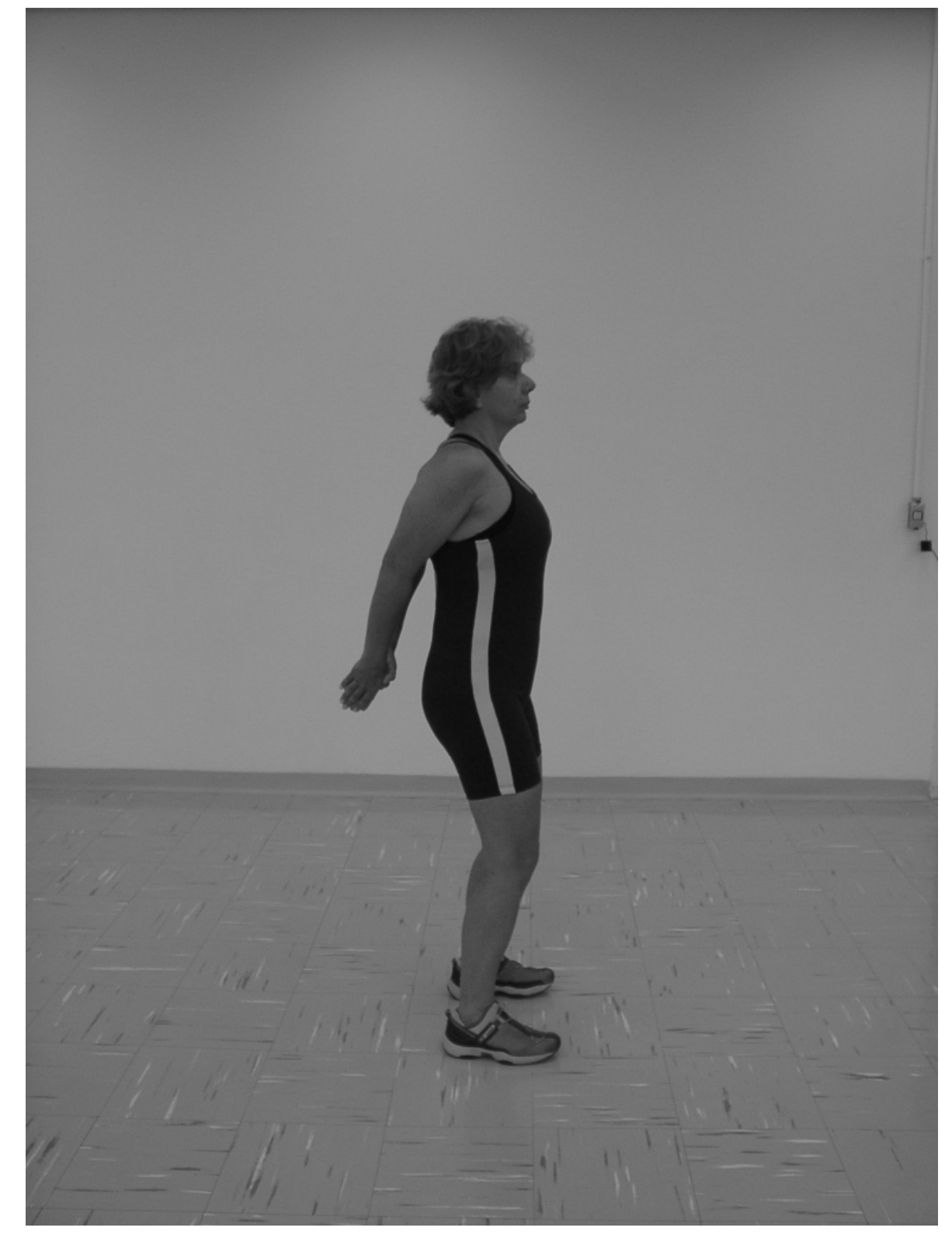




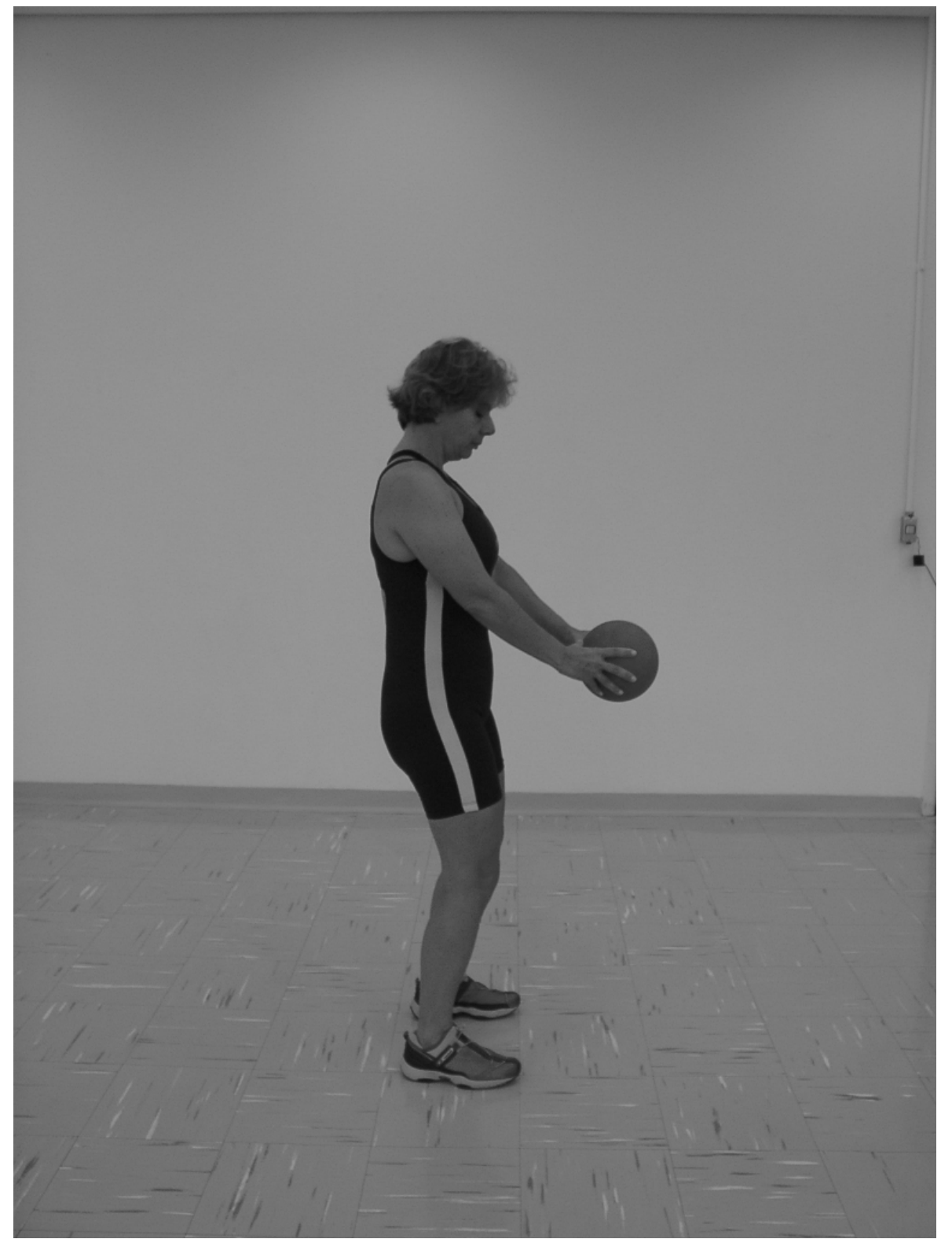




<smiles>[2H]C=C=[CH]</smiles> 

SEGUNDA SEMANA 


$$
\text { i1 }
$$




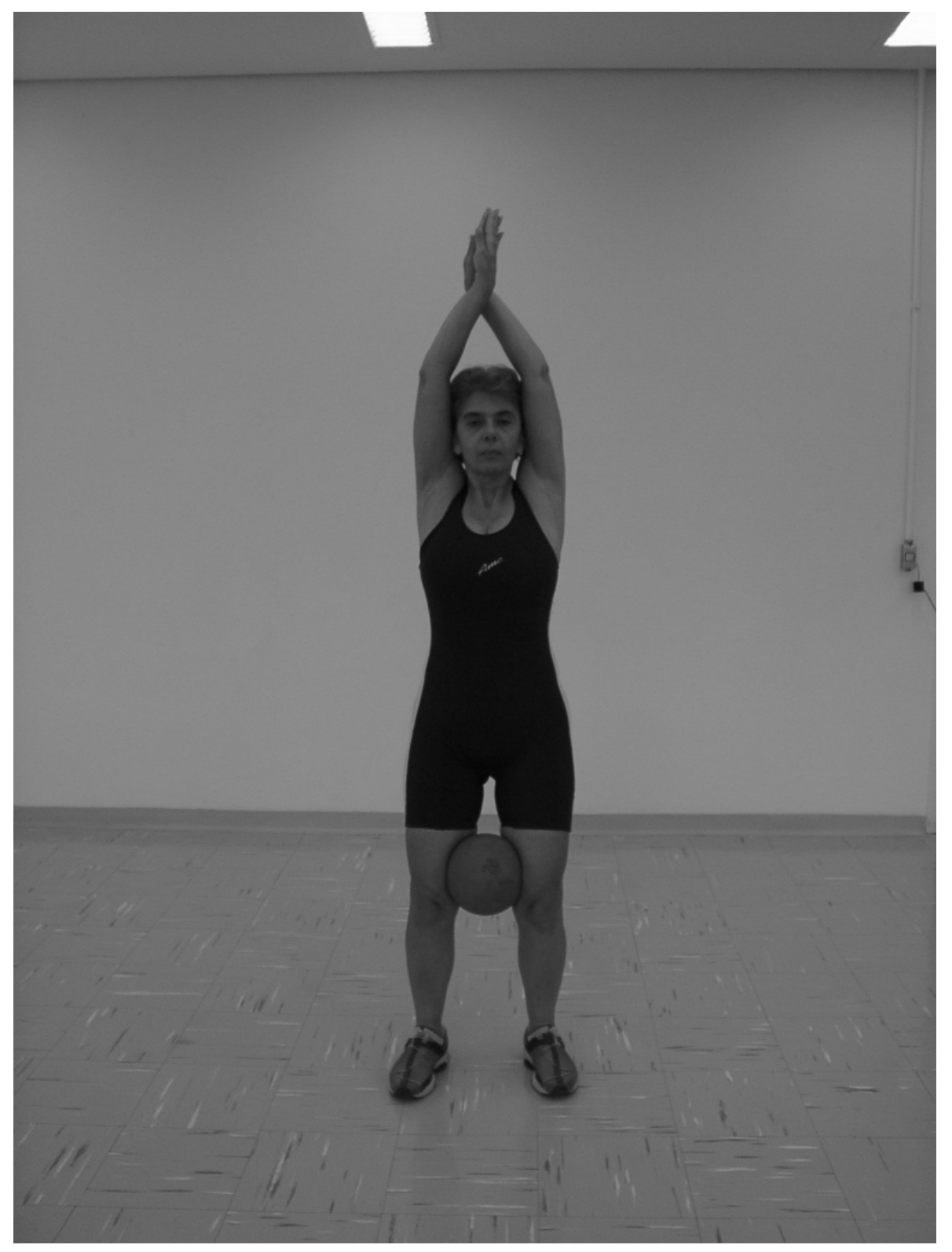


? 




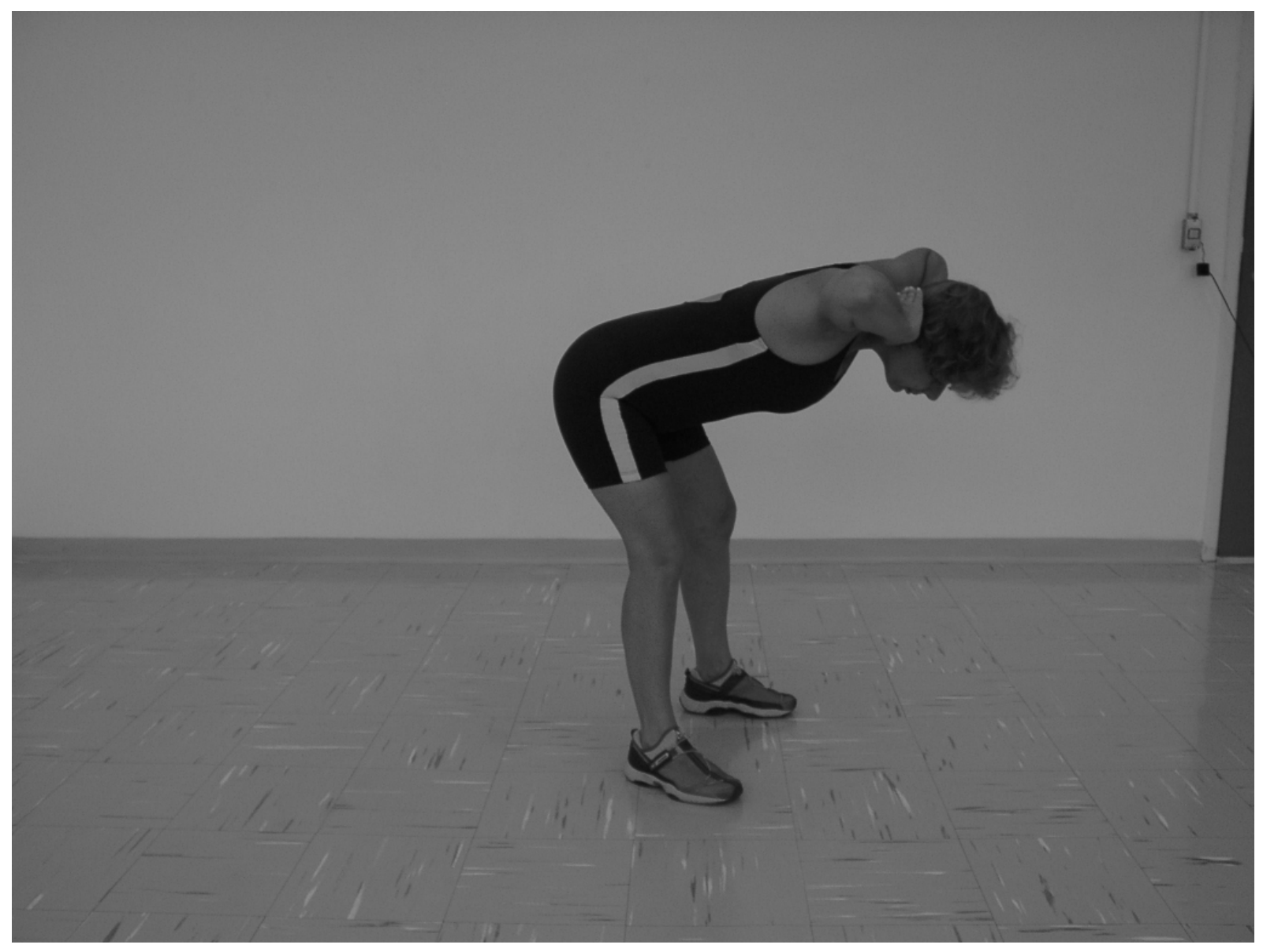




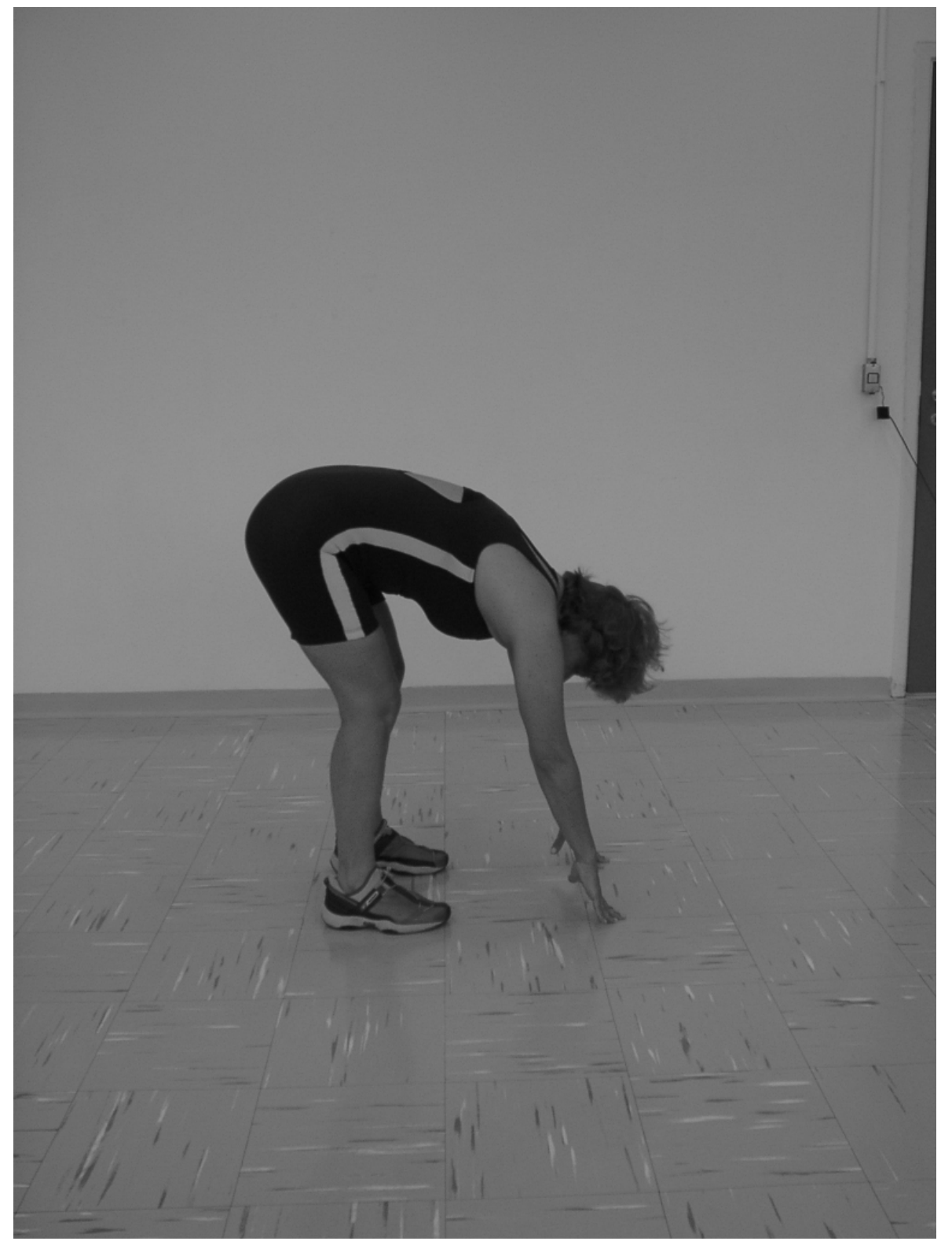





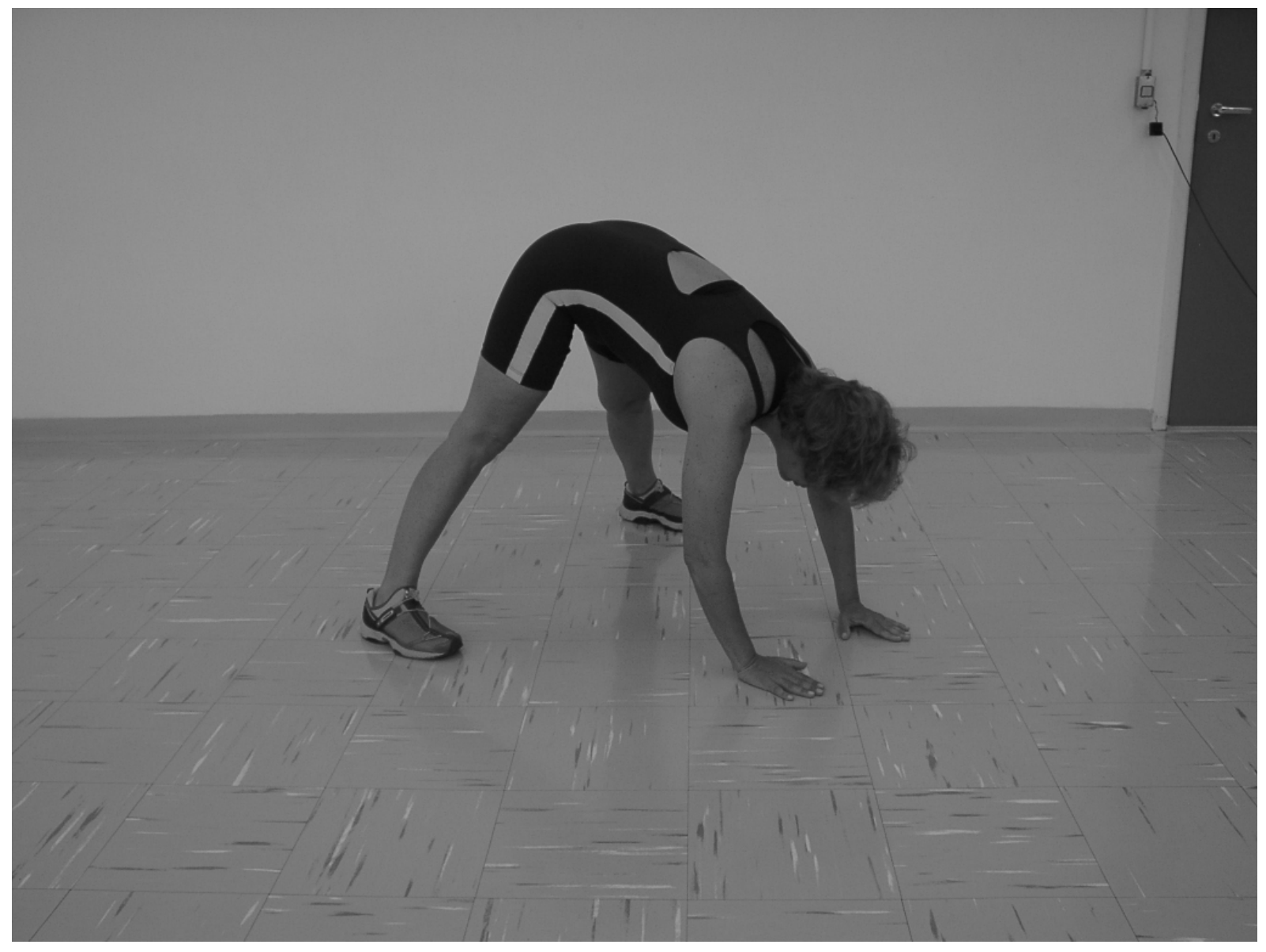




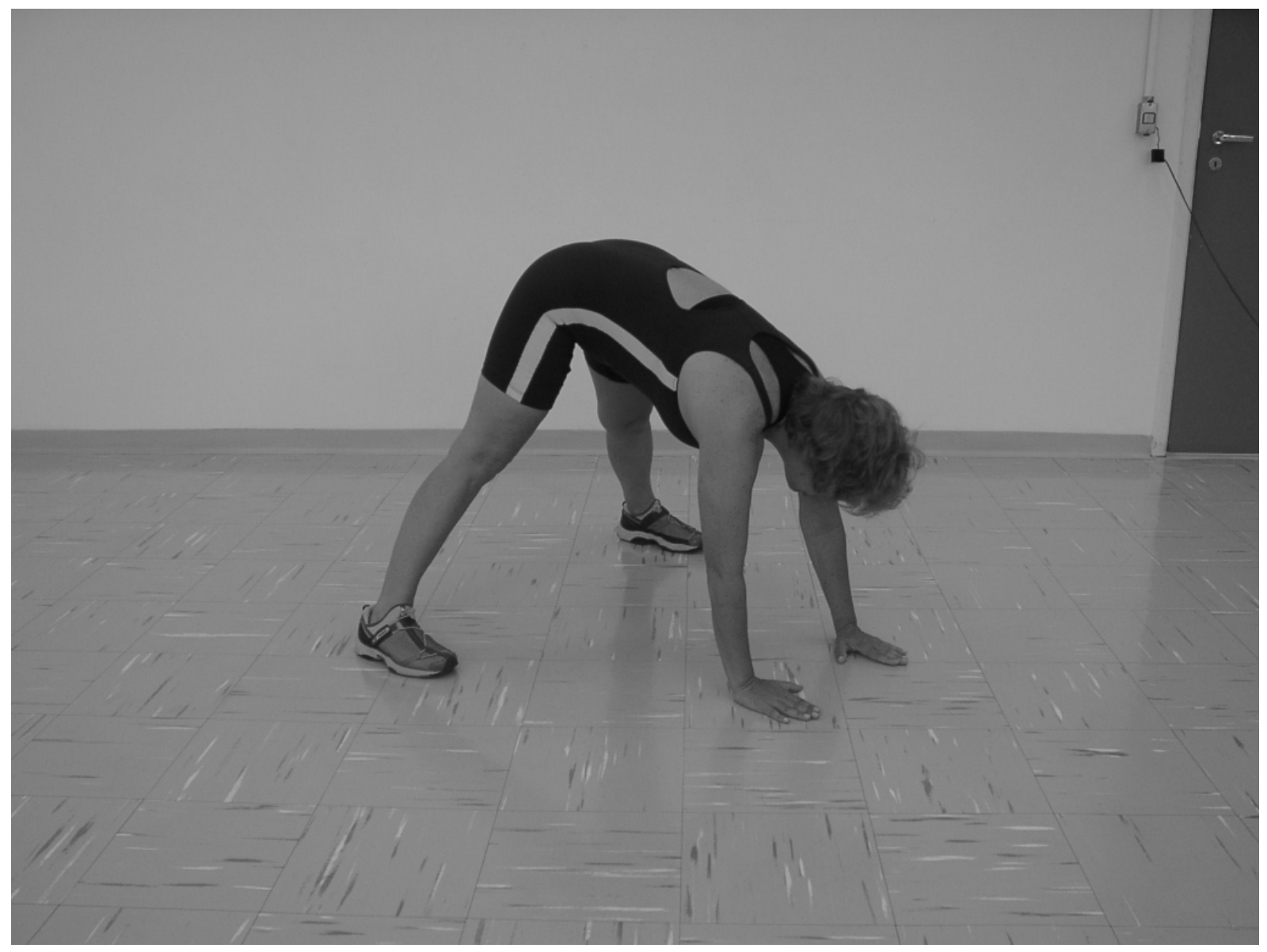




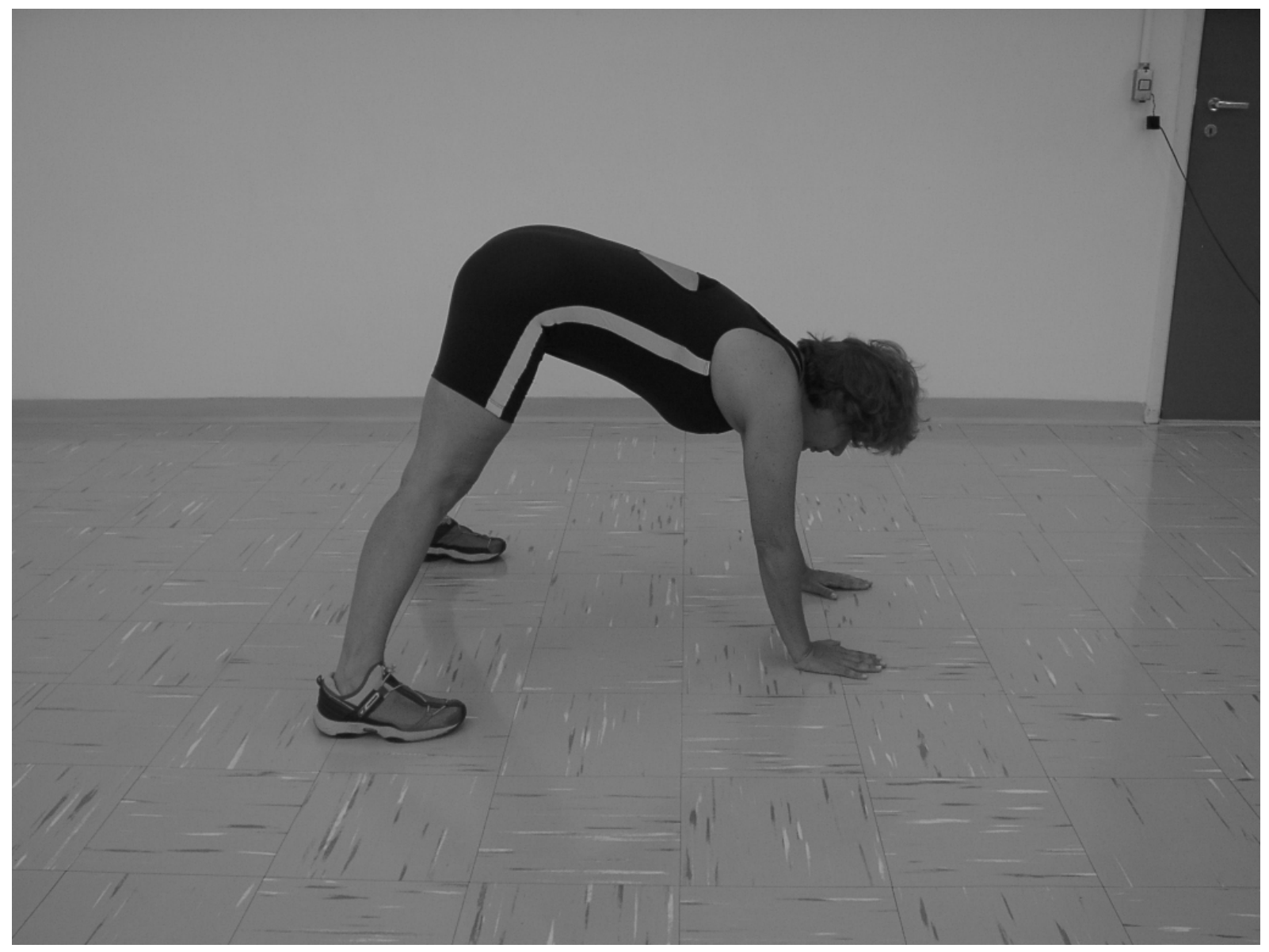


a 


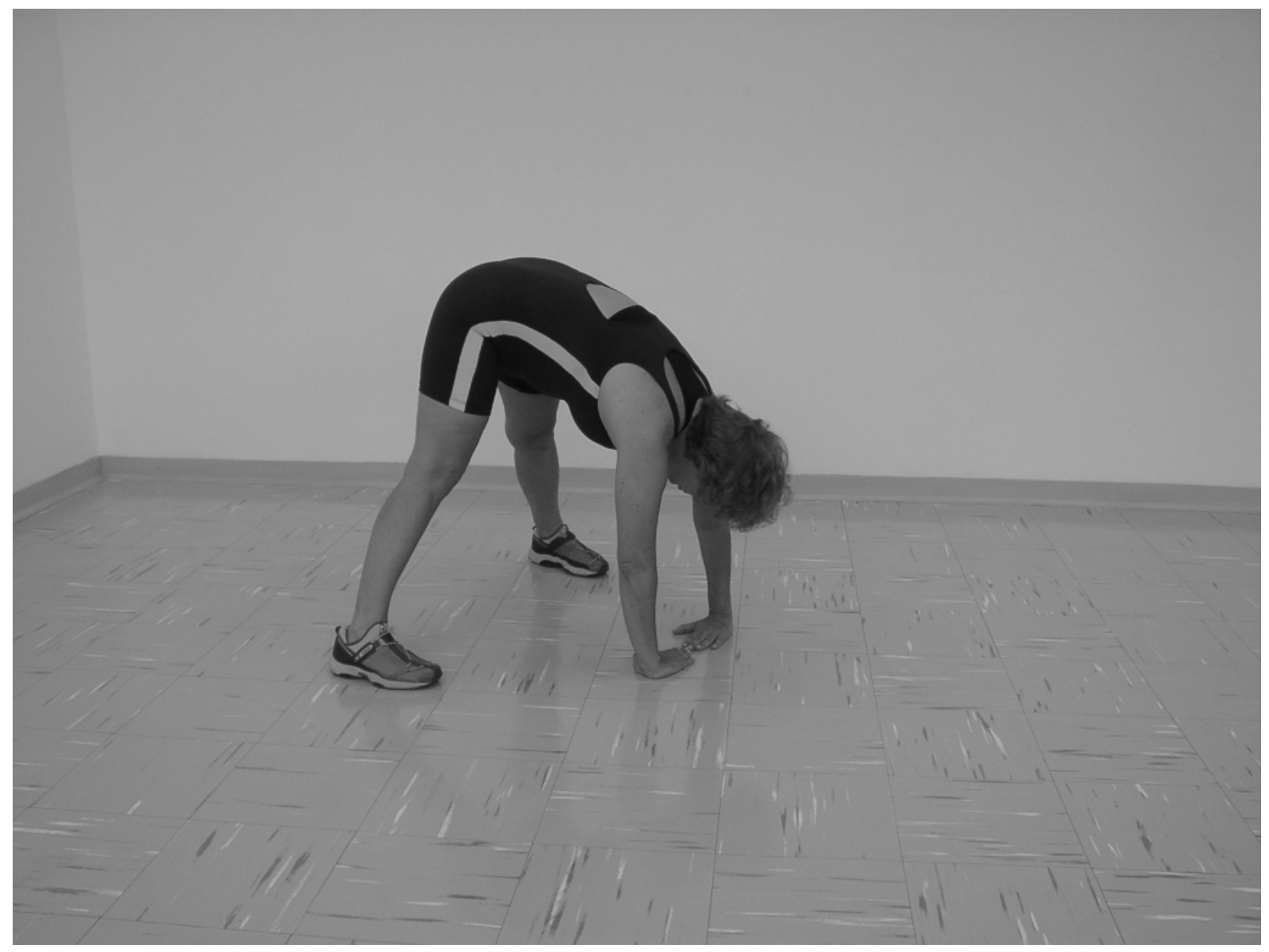




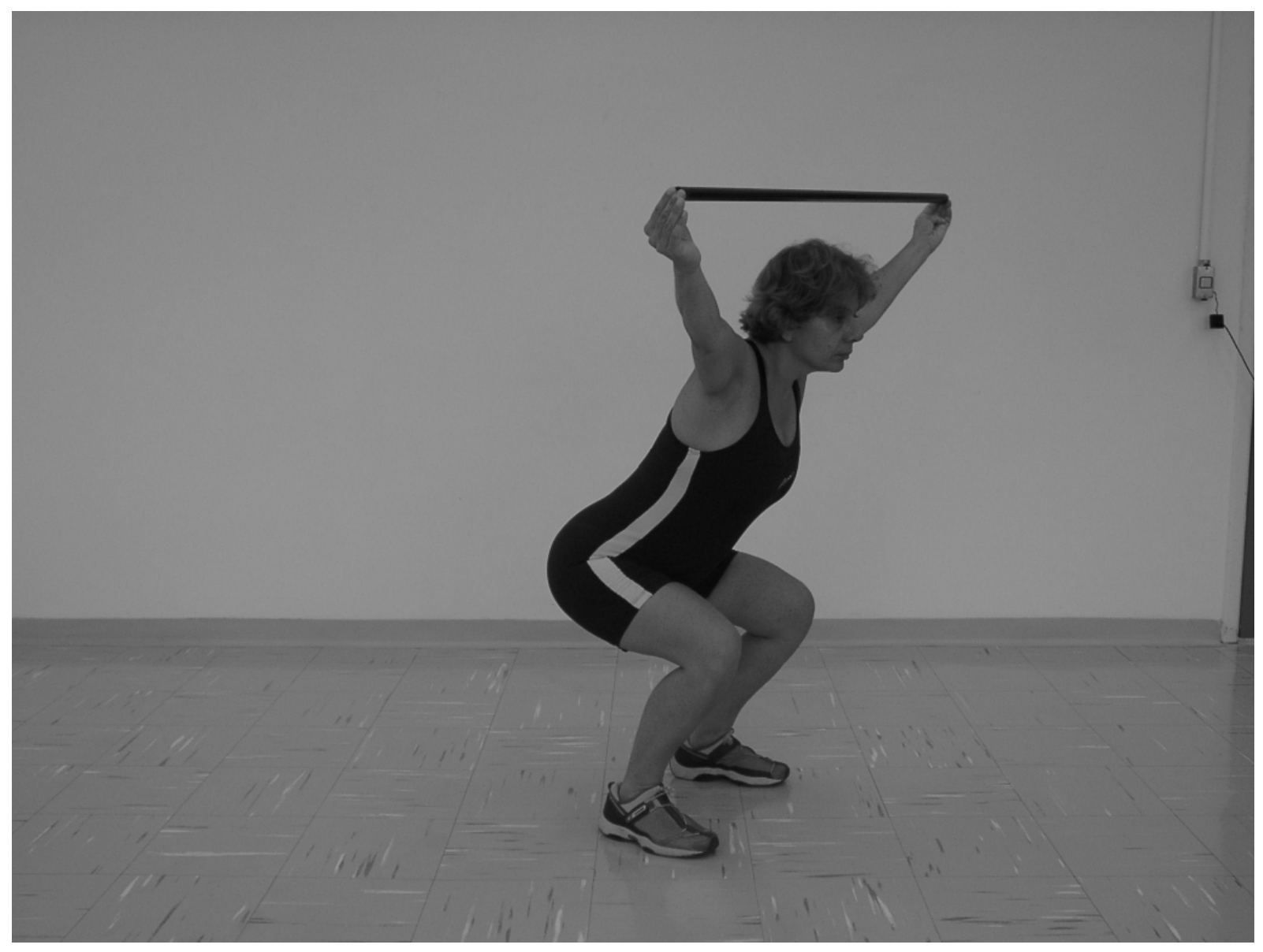


TERCEIRA SEMANA 


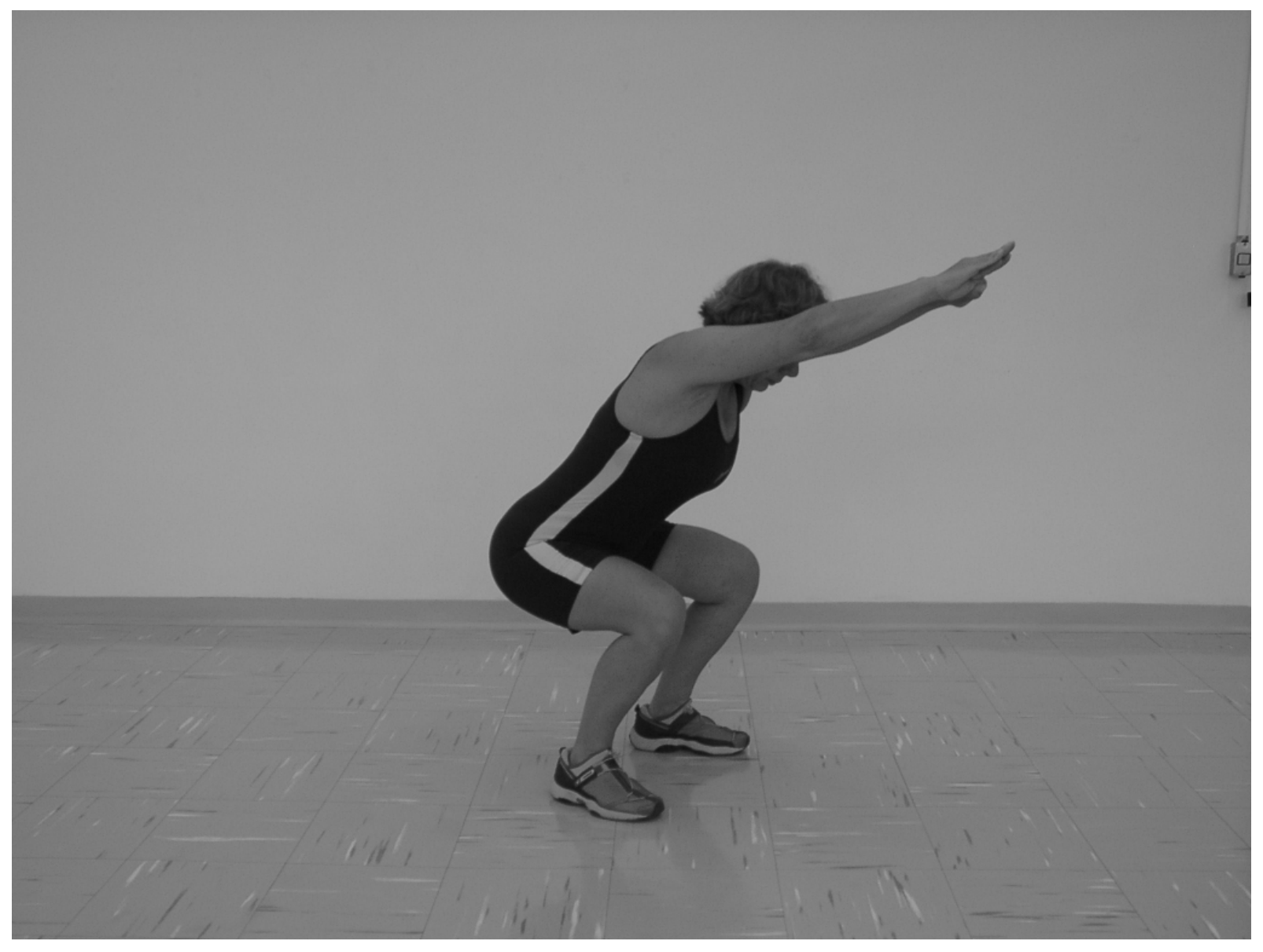




$$
8
$$




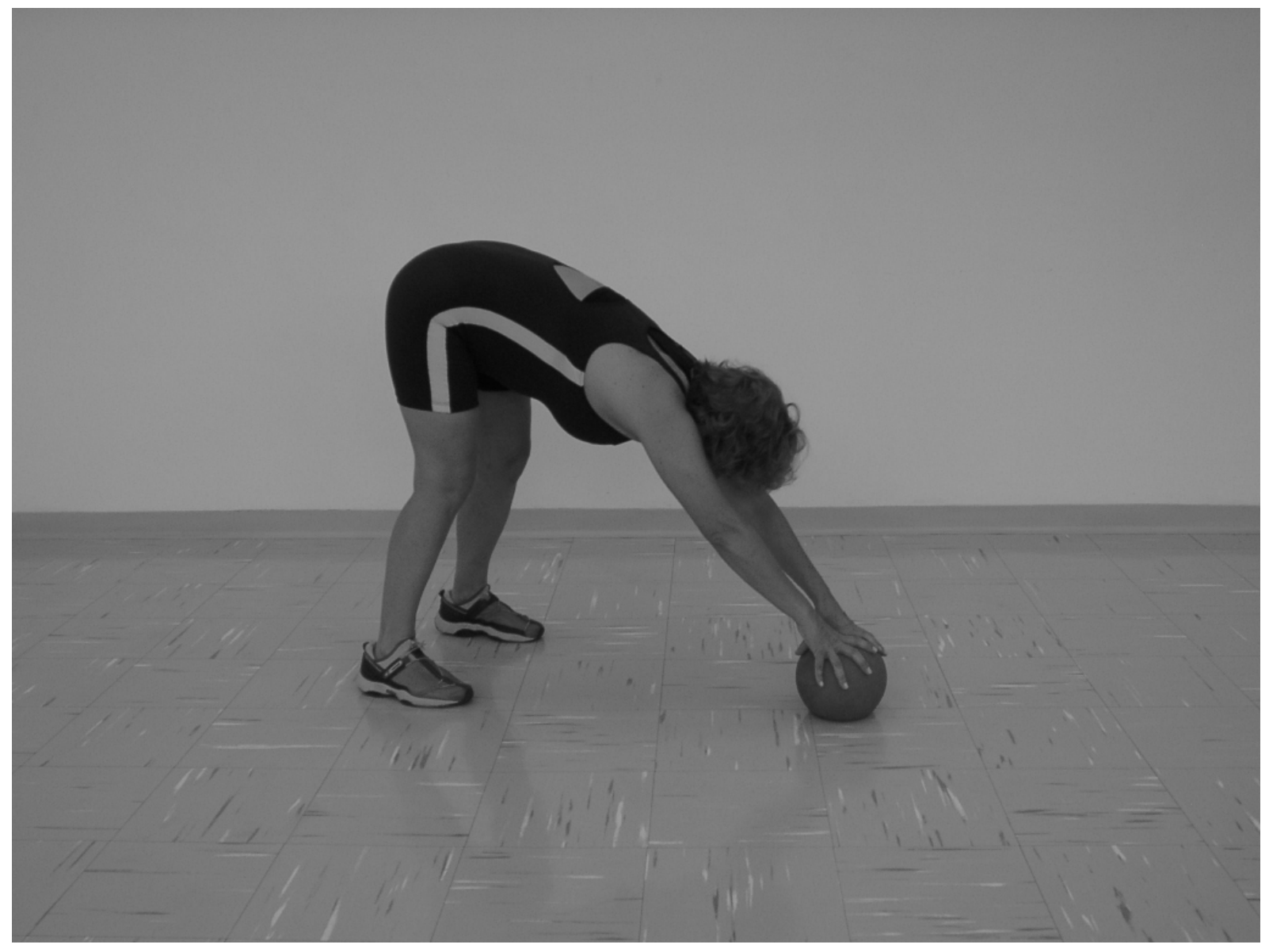




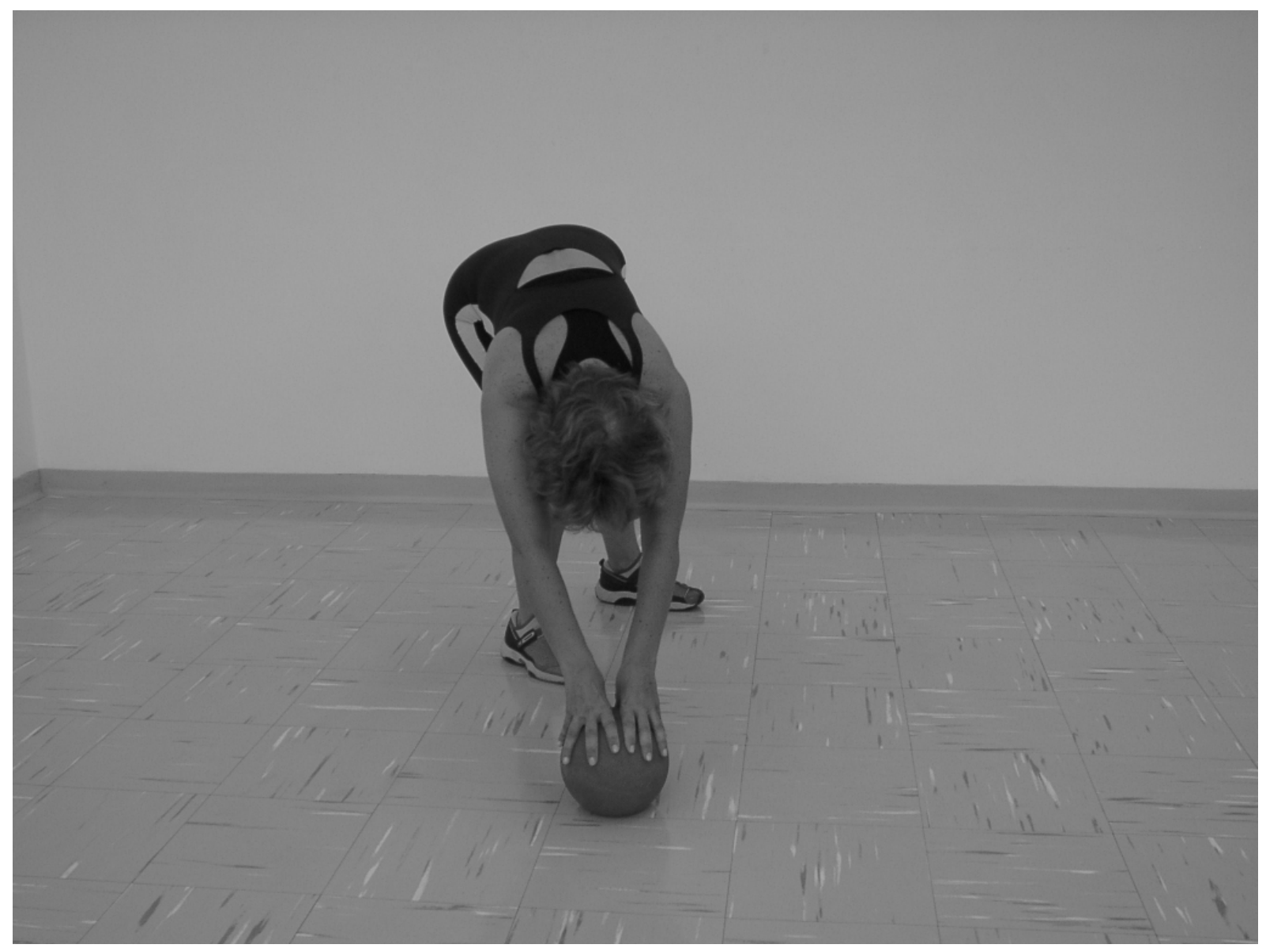




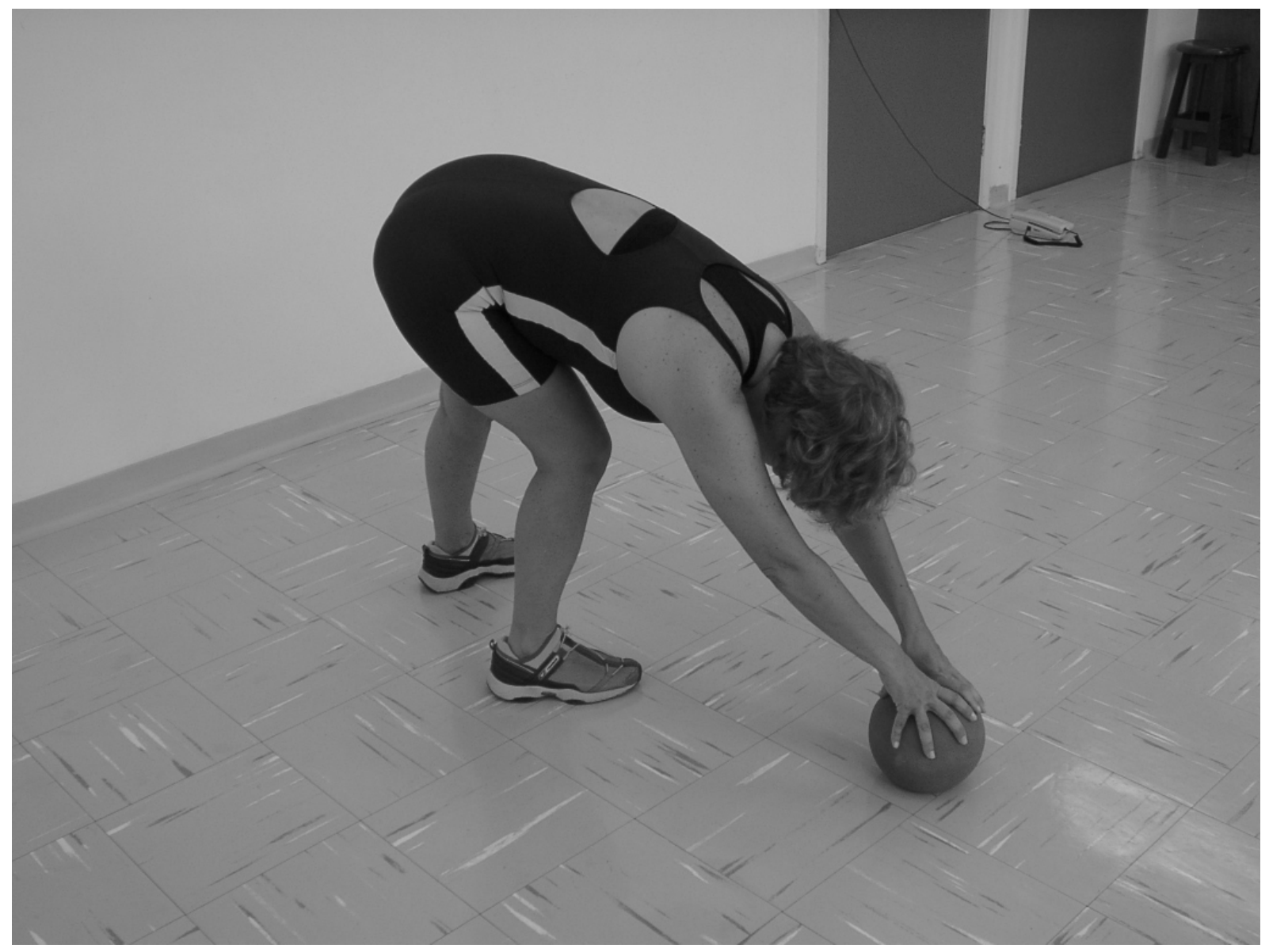





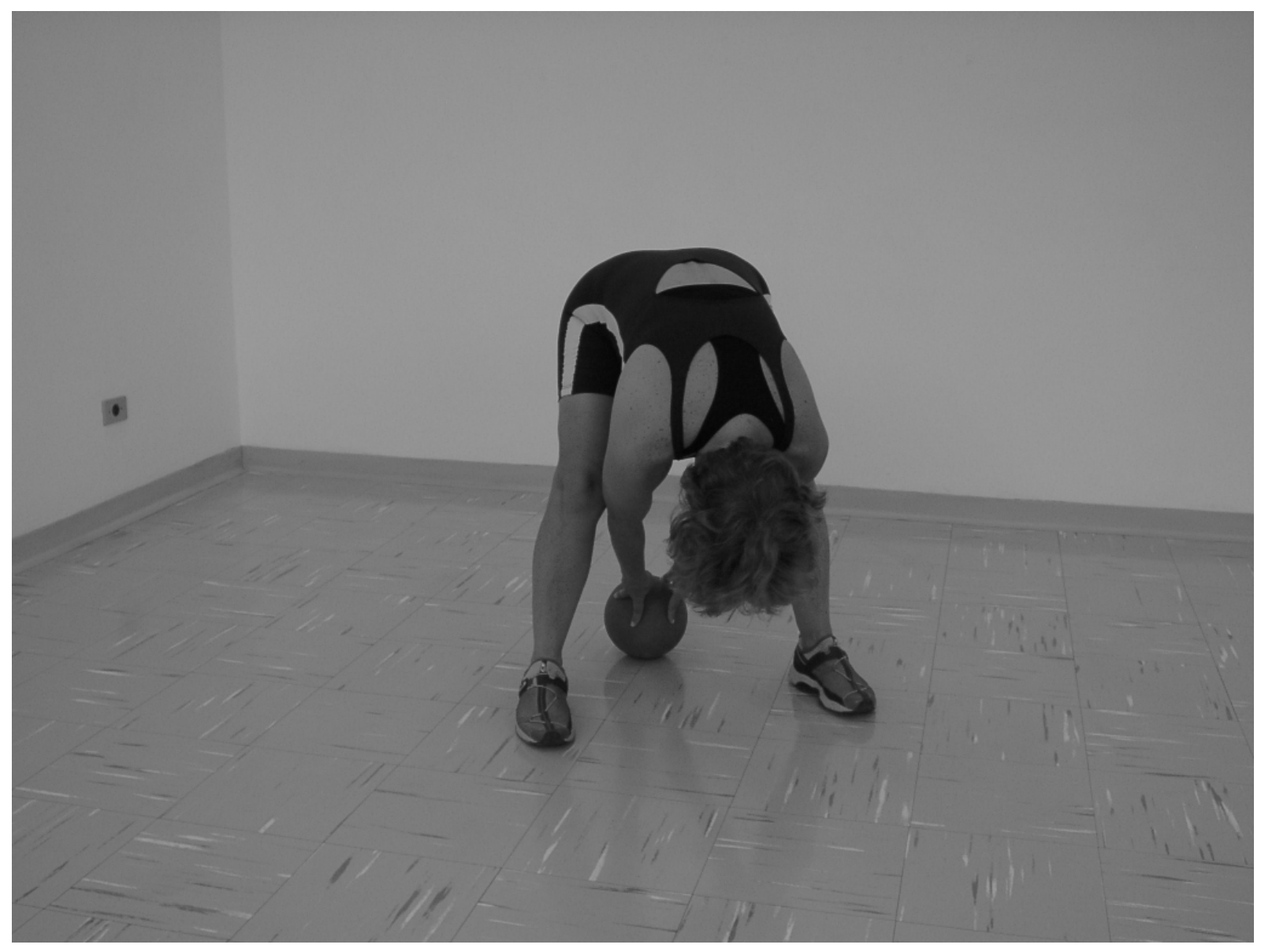




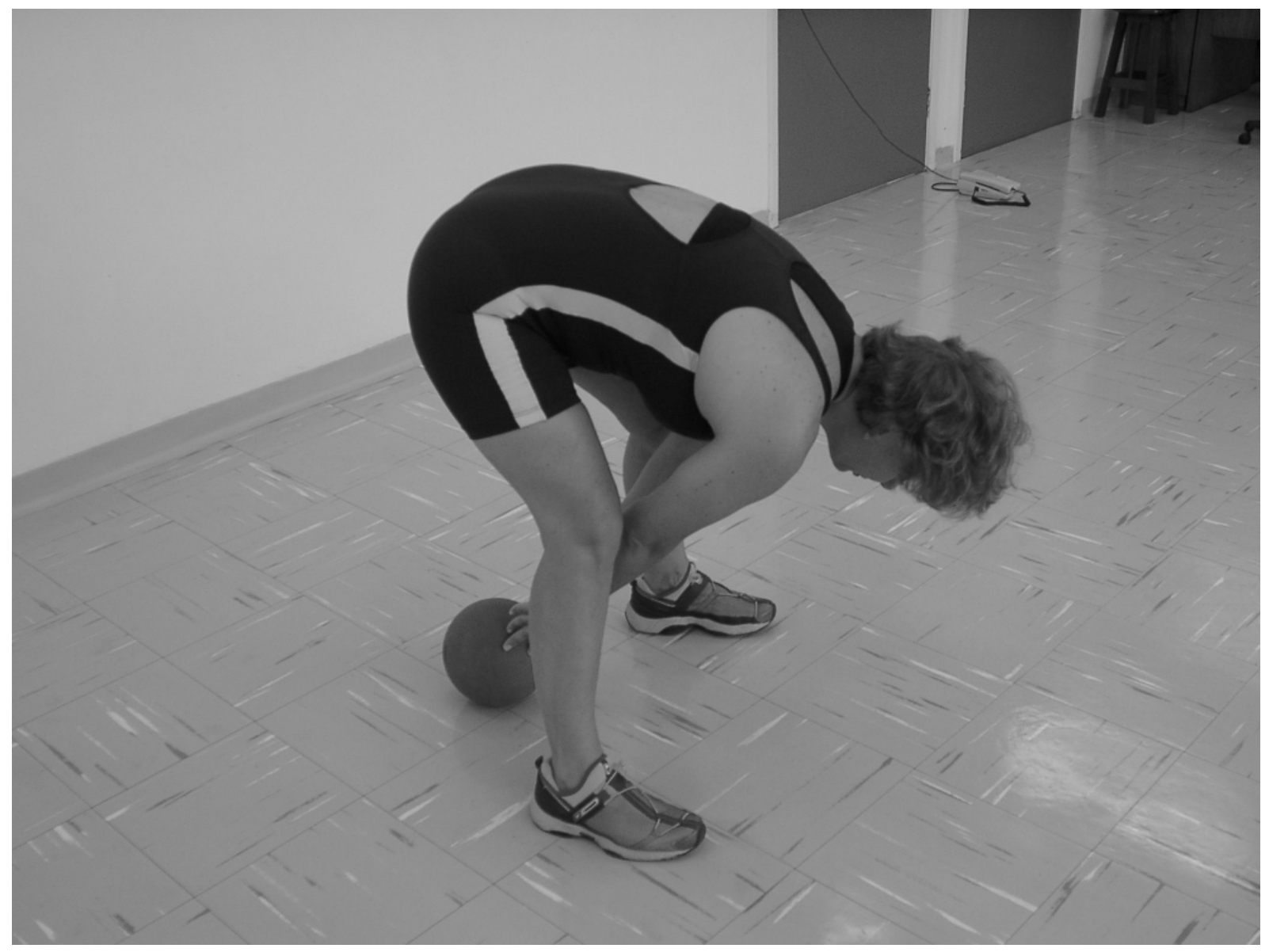




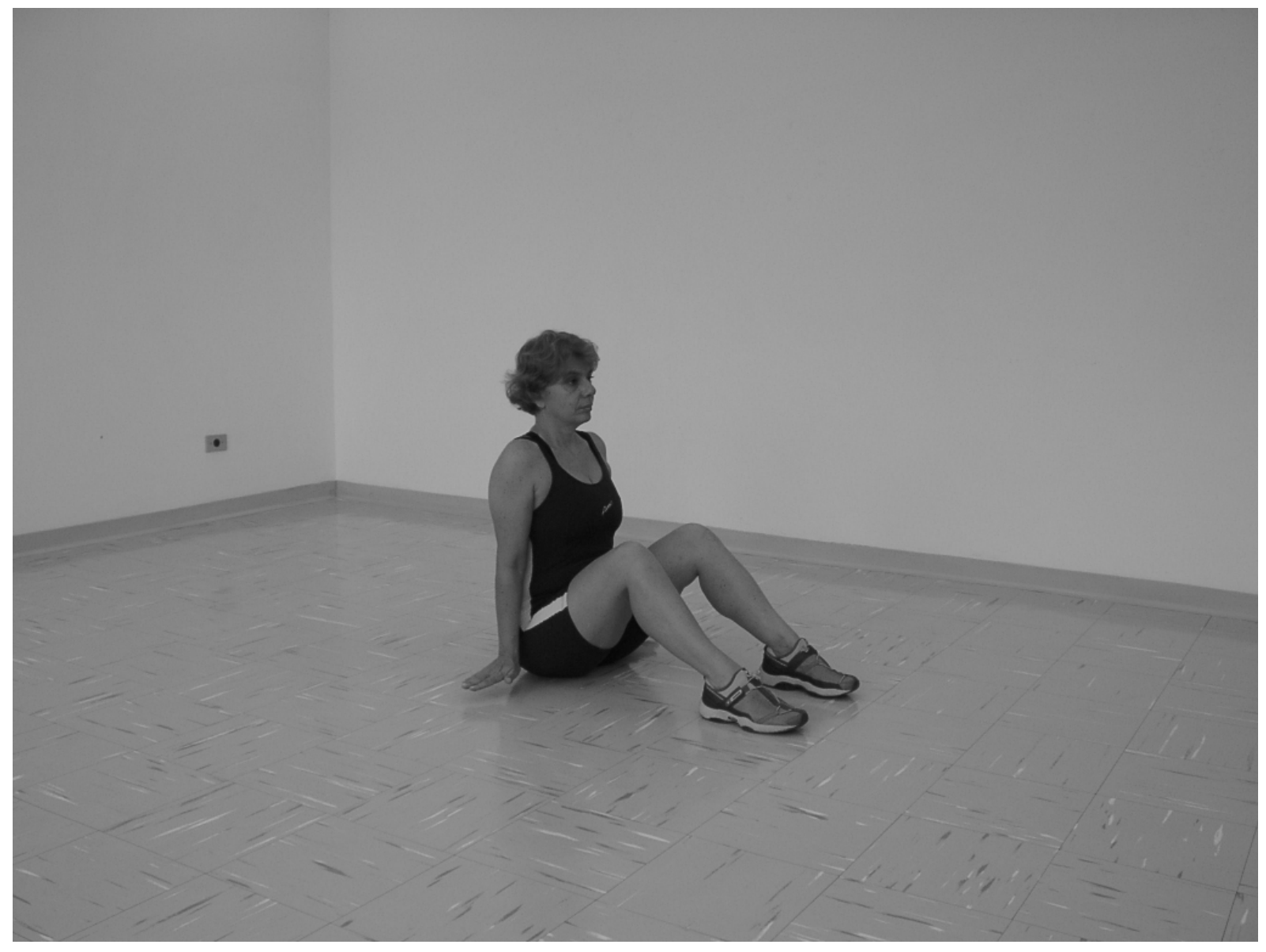



है. 



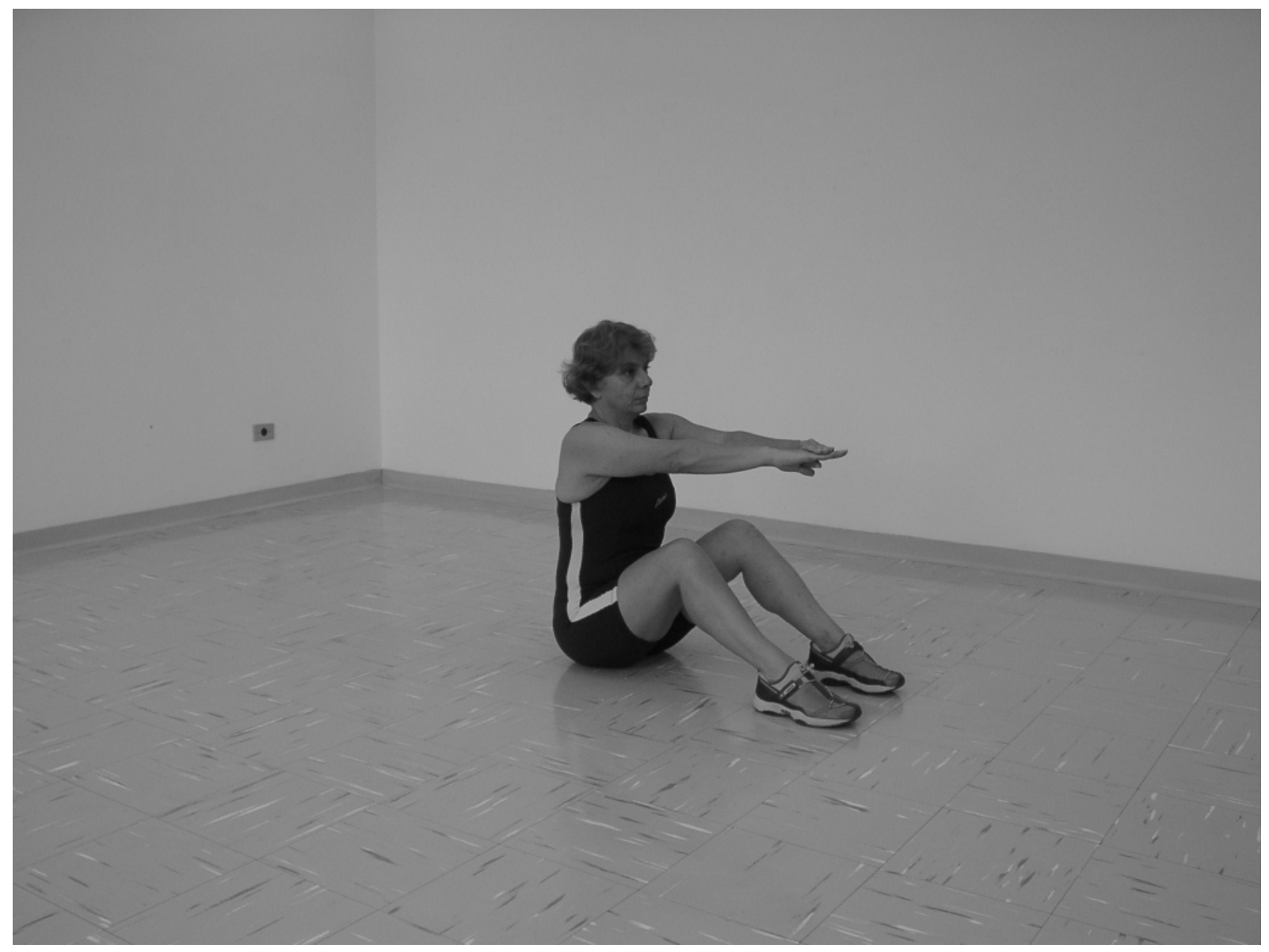





\section{QUARTA SEMANA}




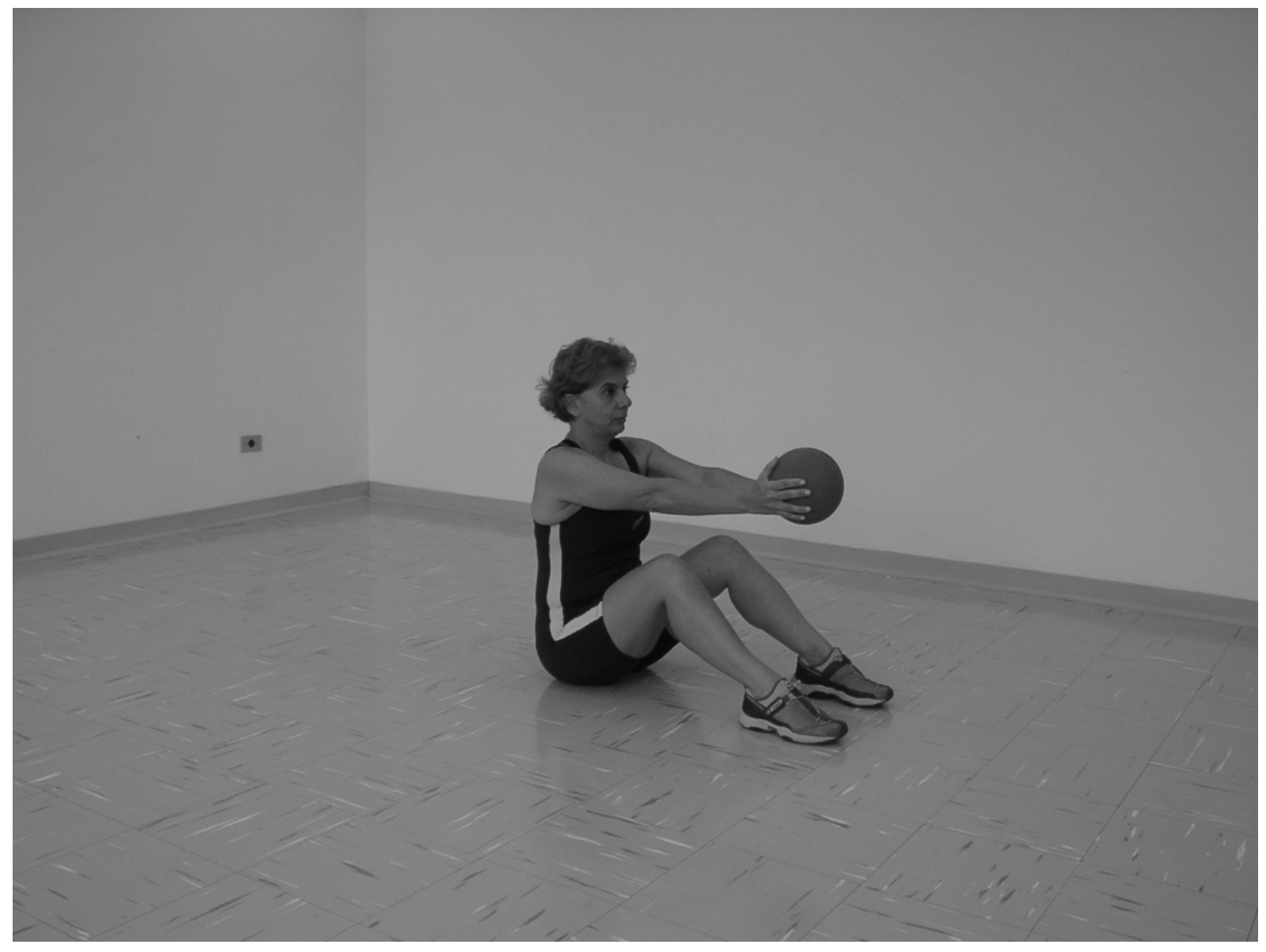




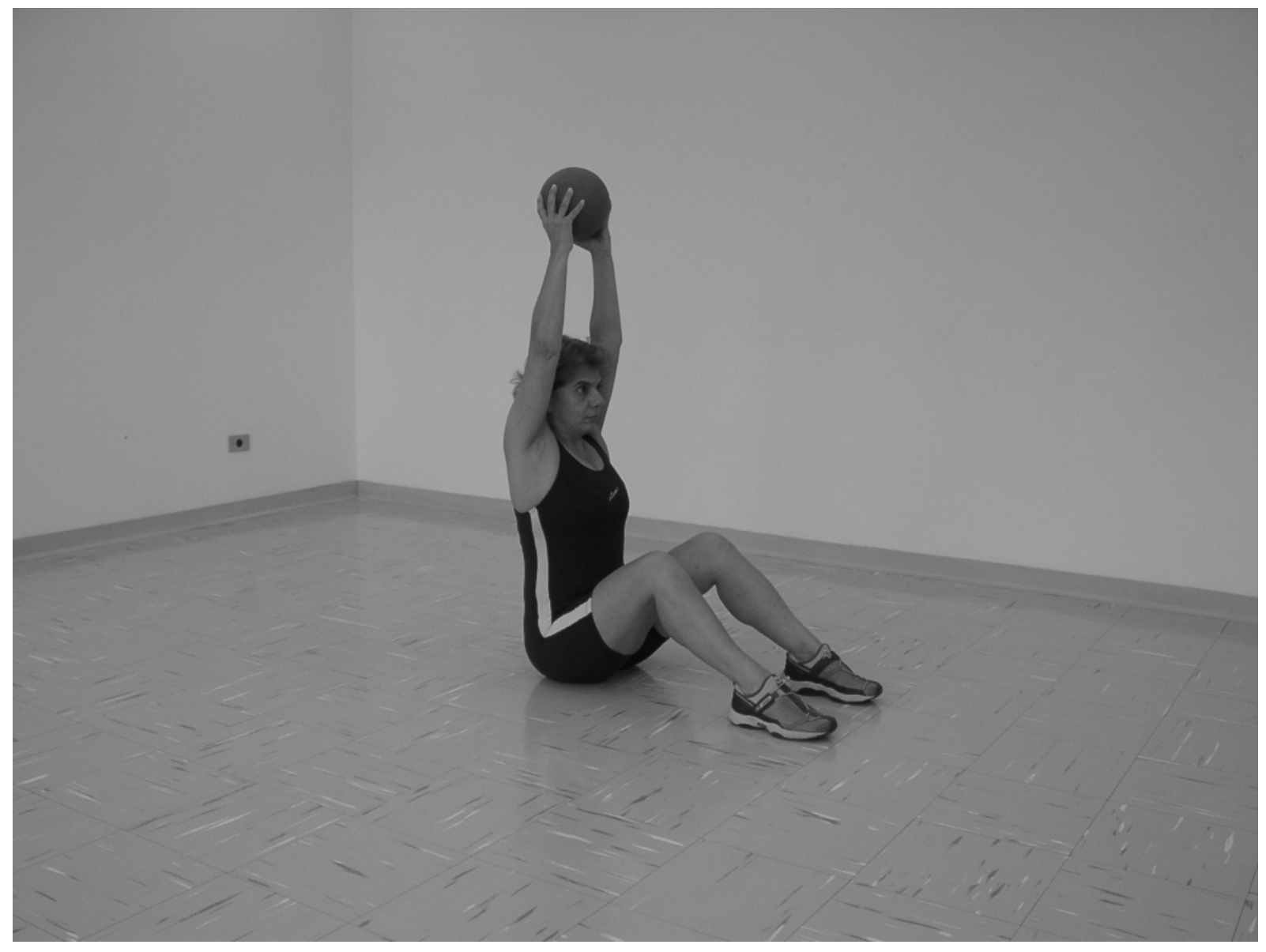




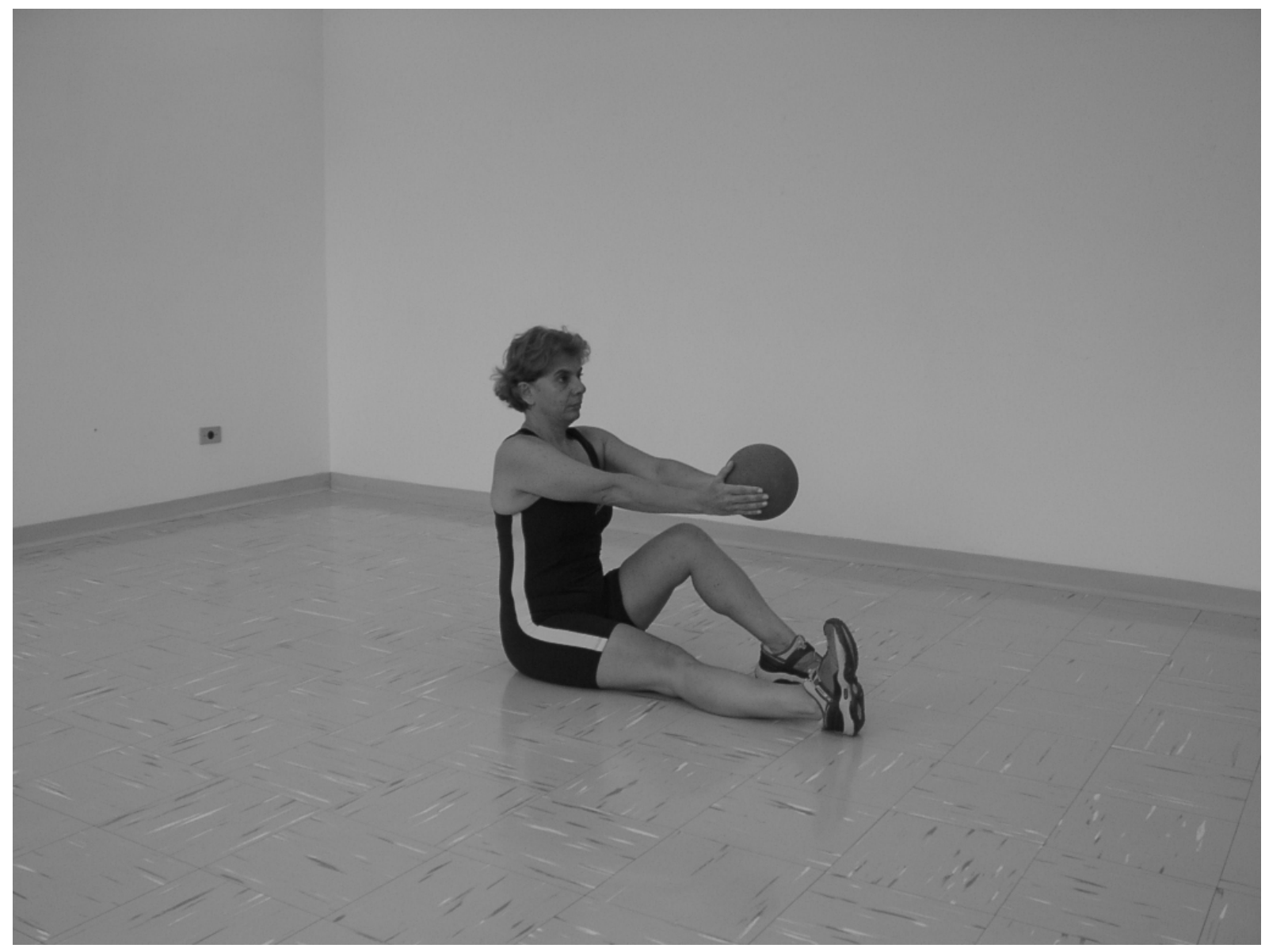





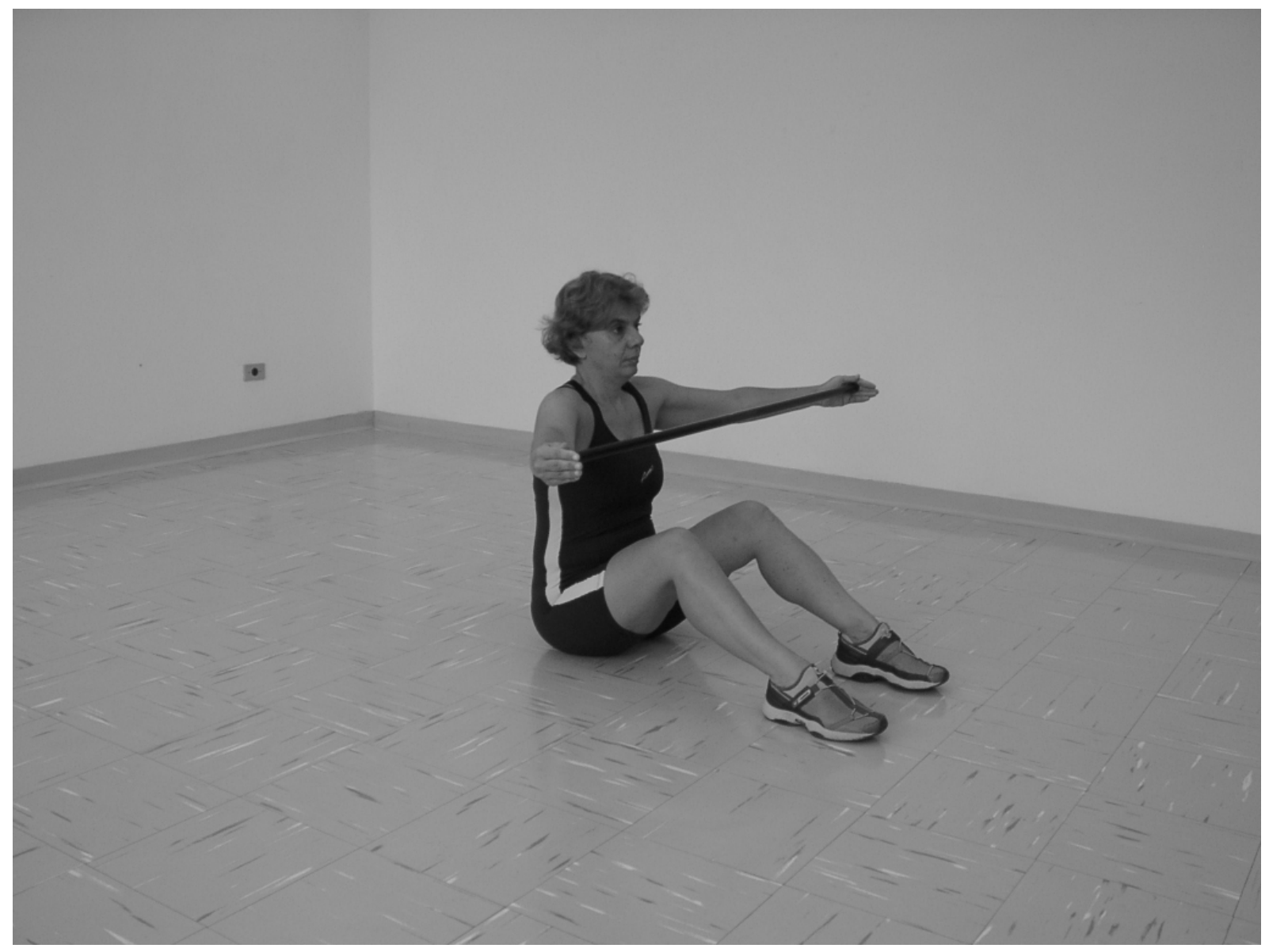




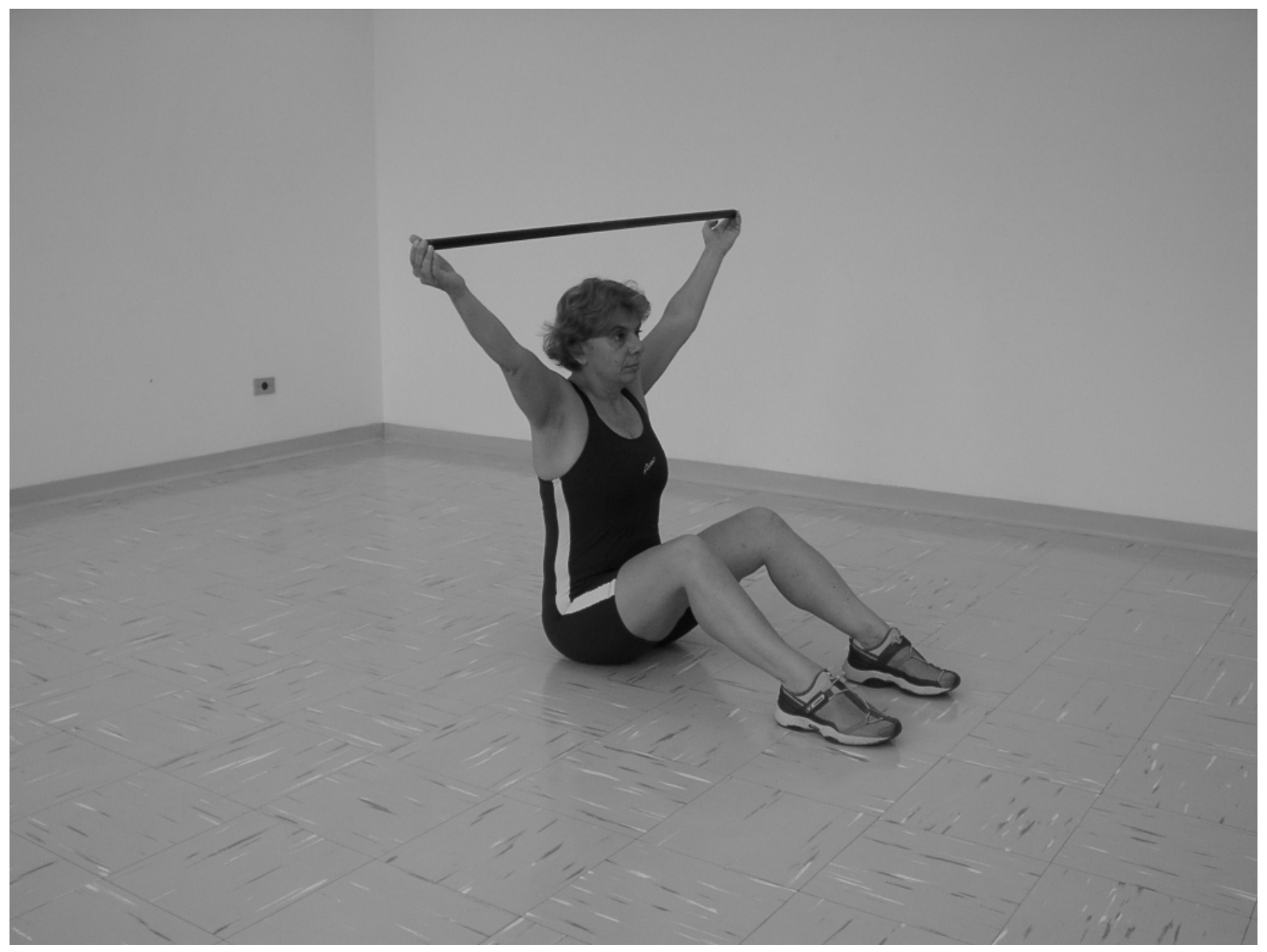




$$
\text { in }
$$




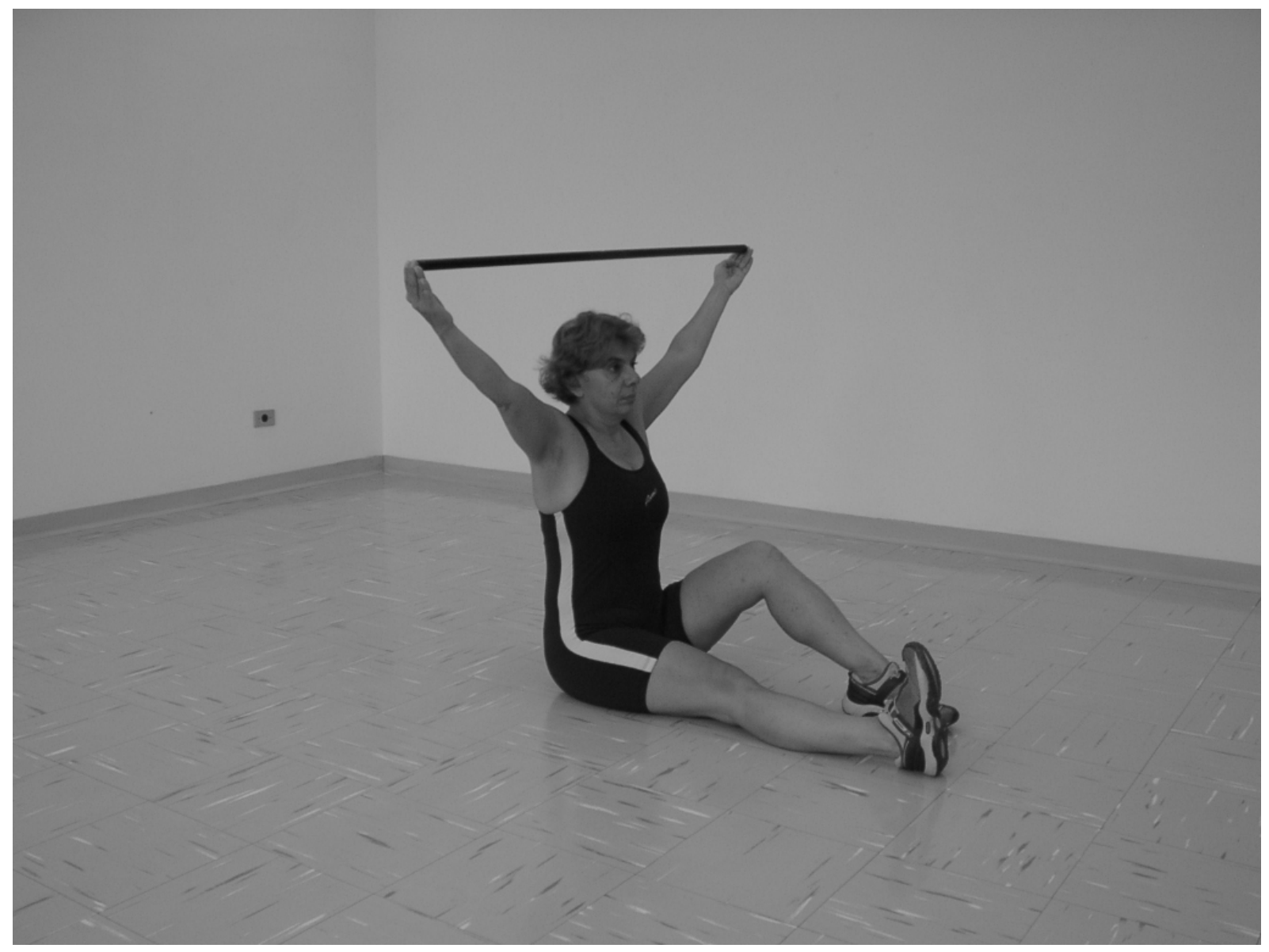




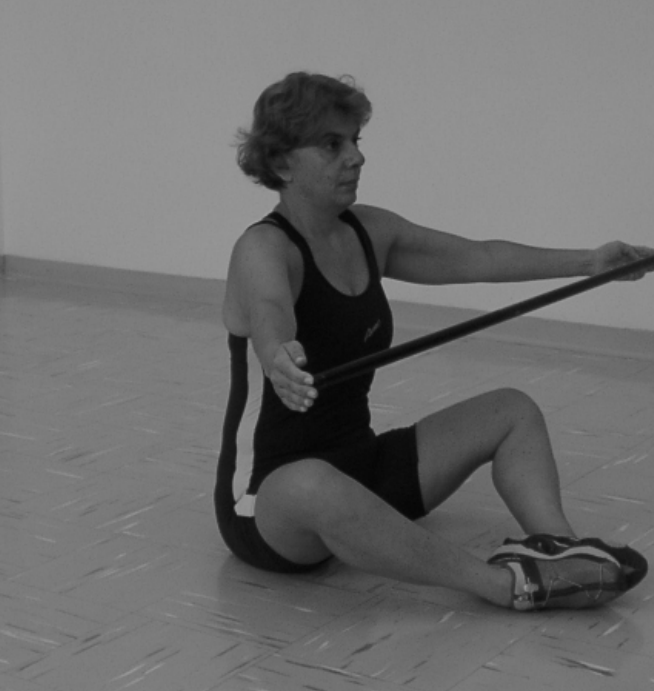




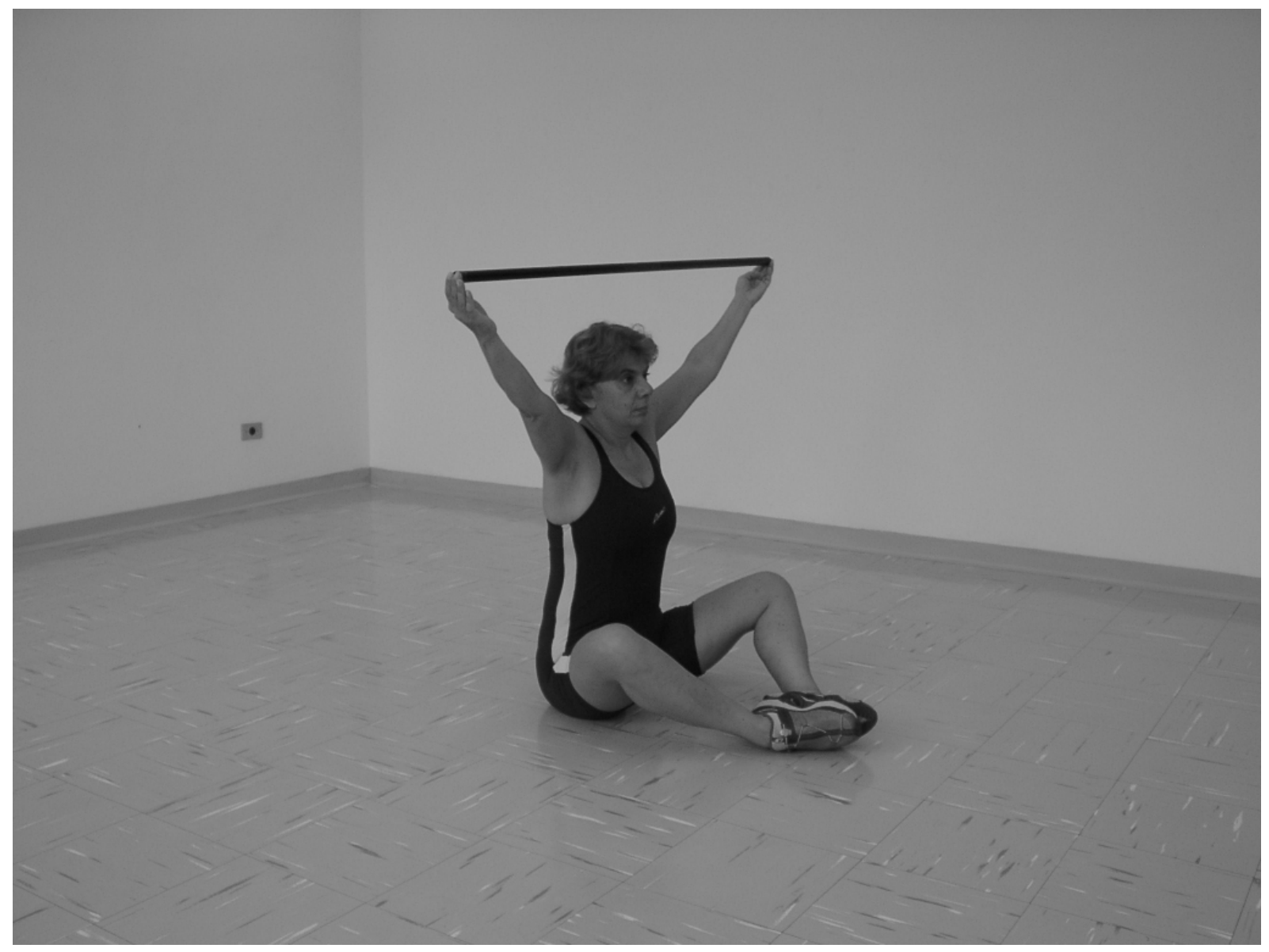




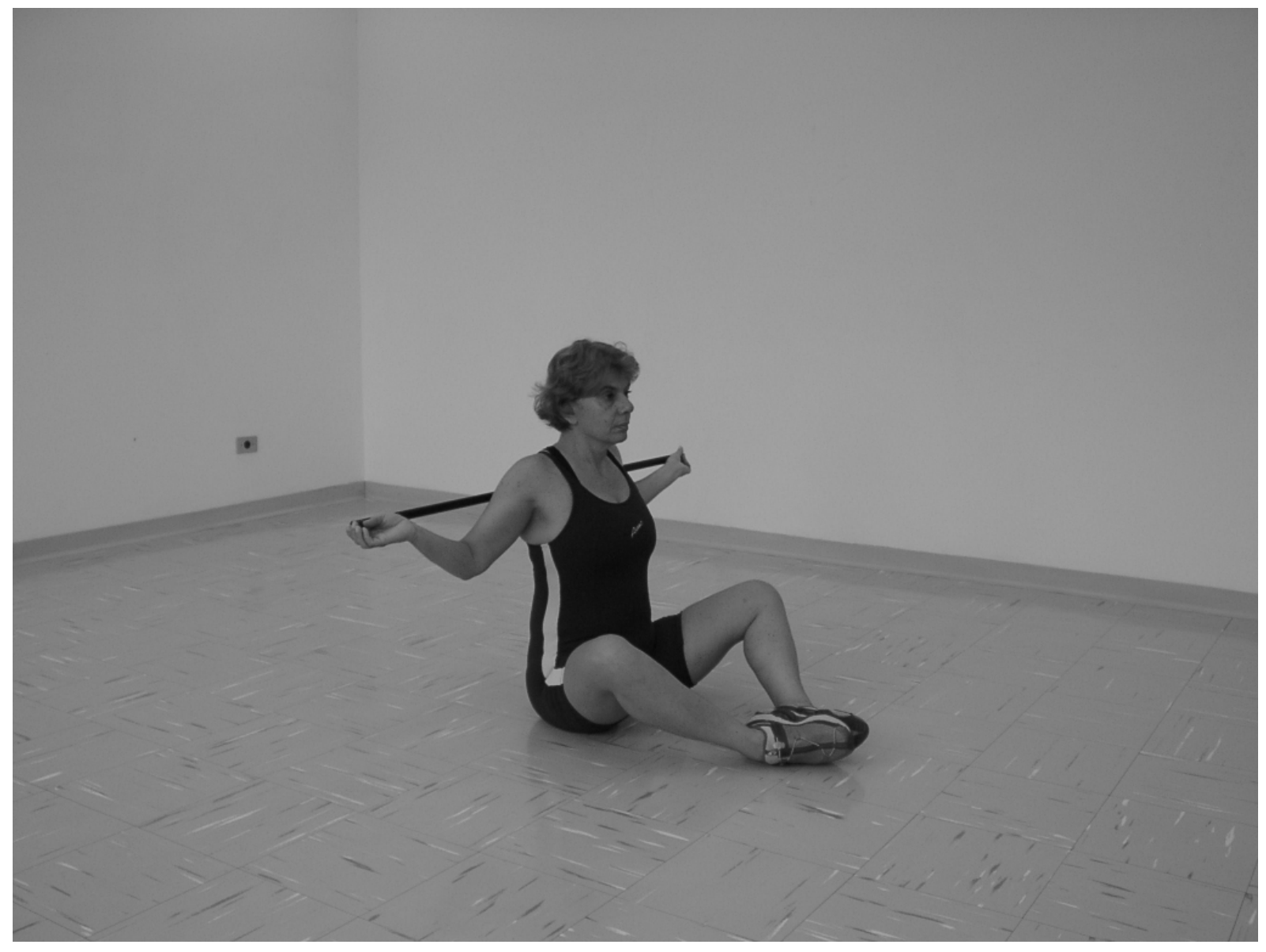




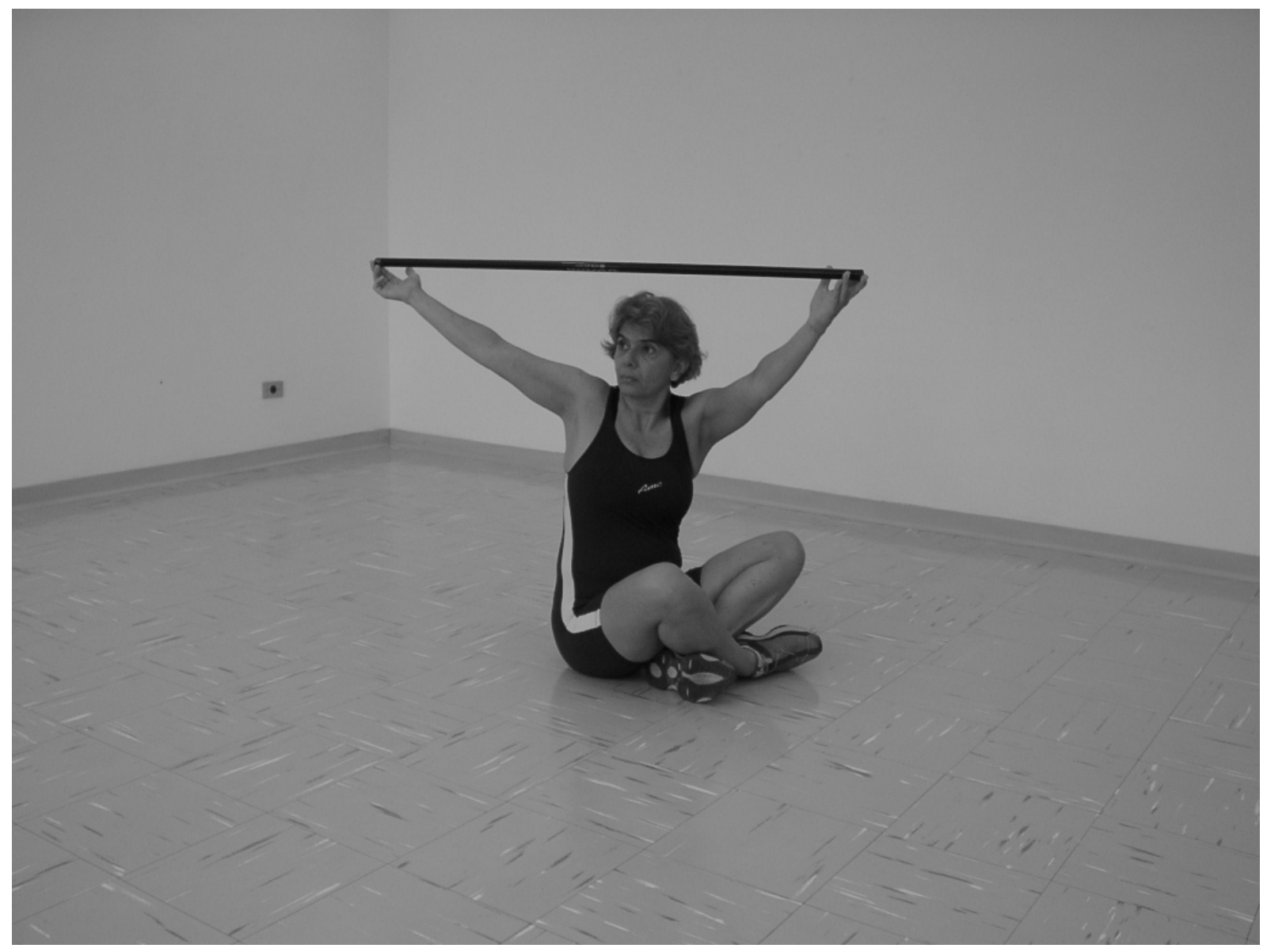




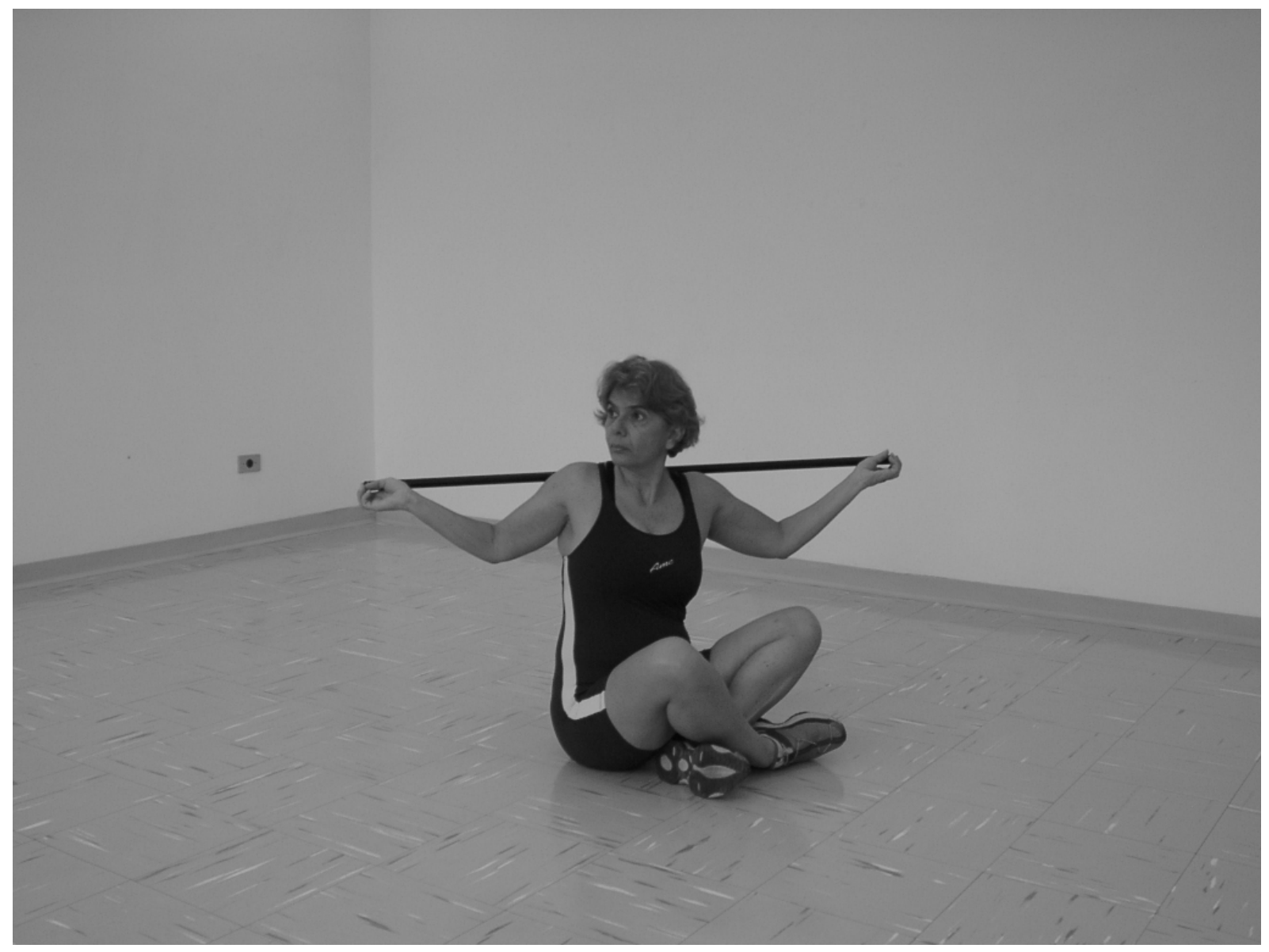


a 


\section{QUINTA SEMANA}





$$
\text { is }
$$




$$
\pi
$$




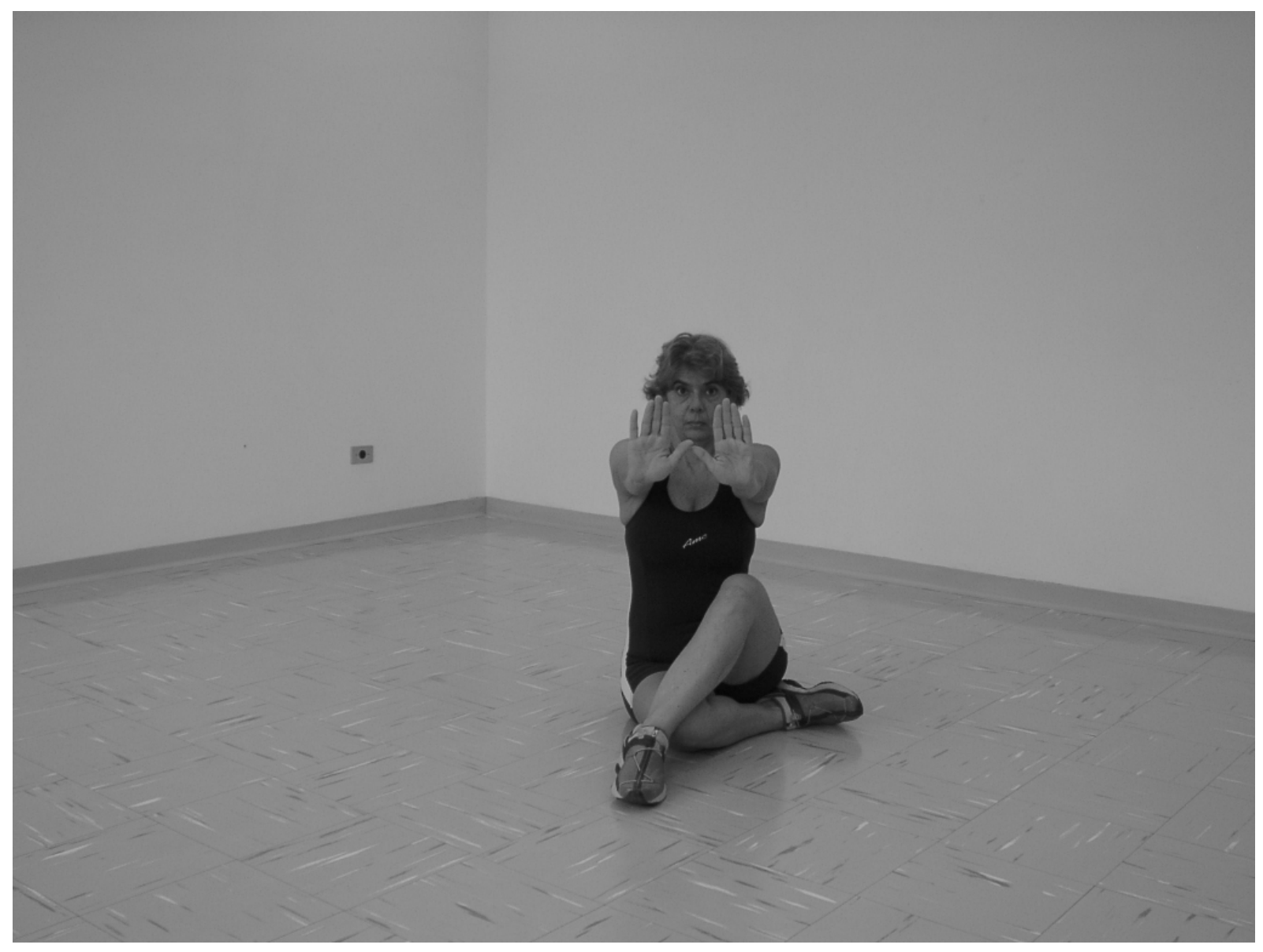




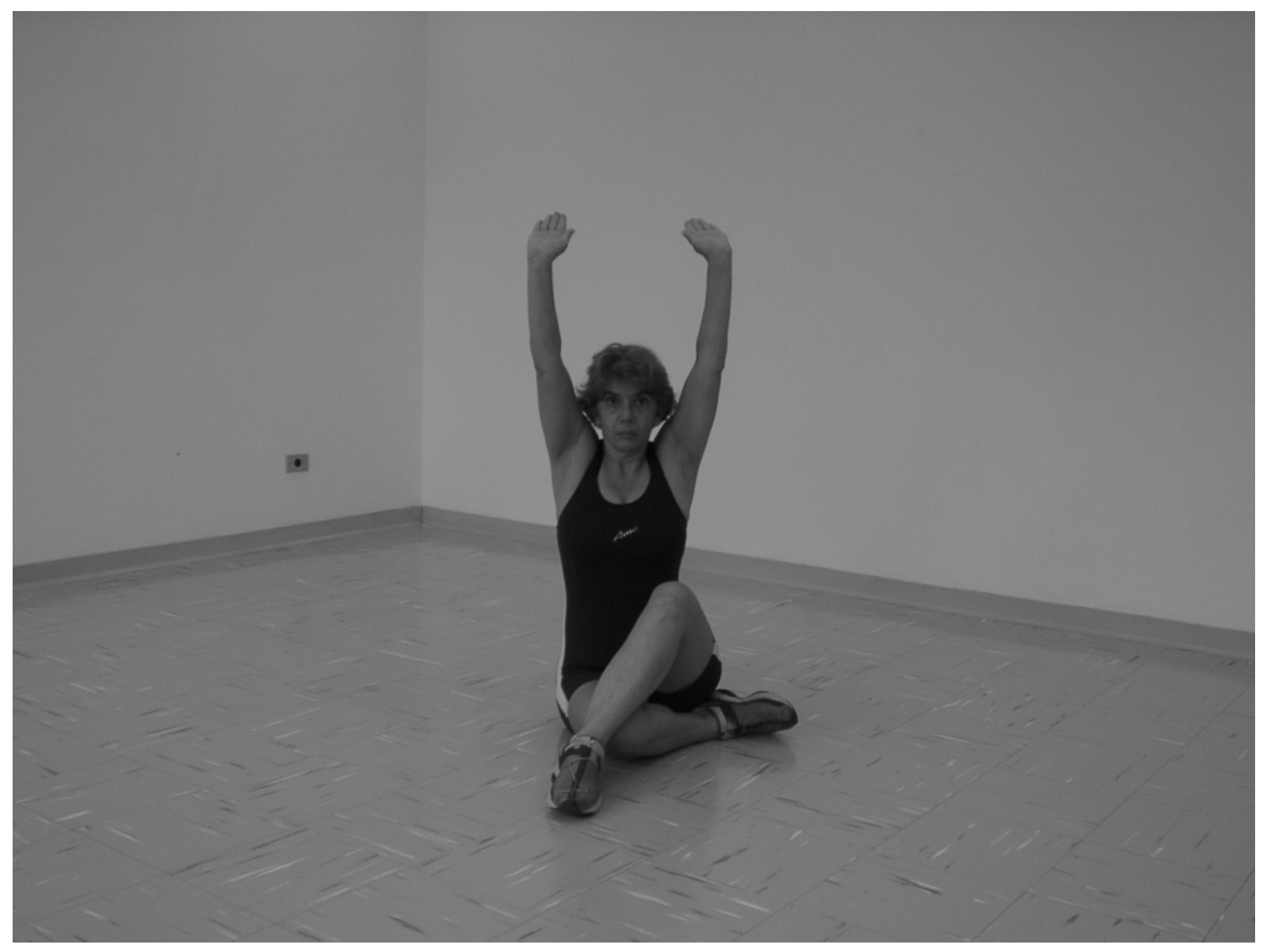




$$
\text { b }
$$




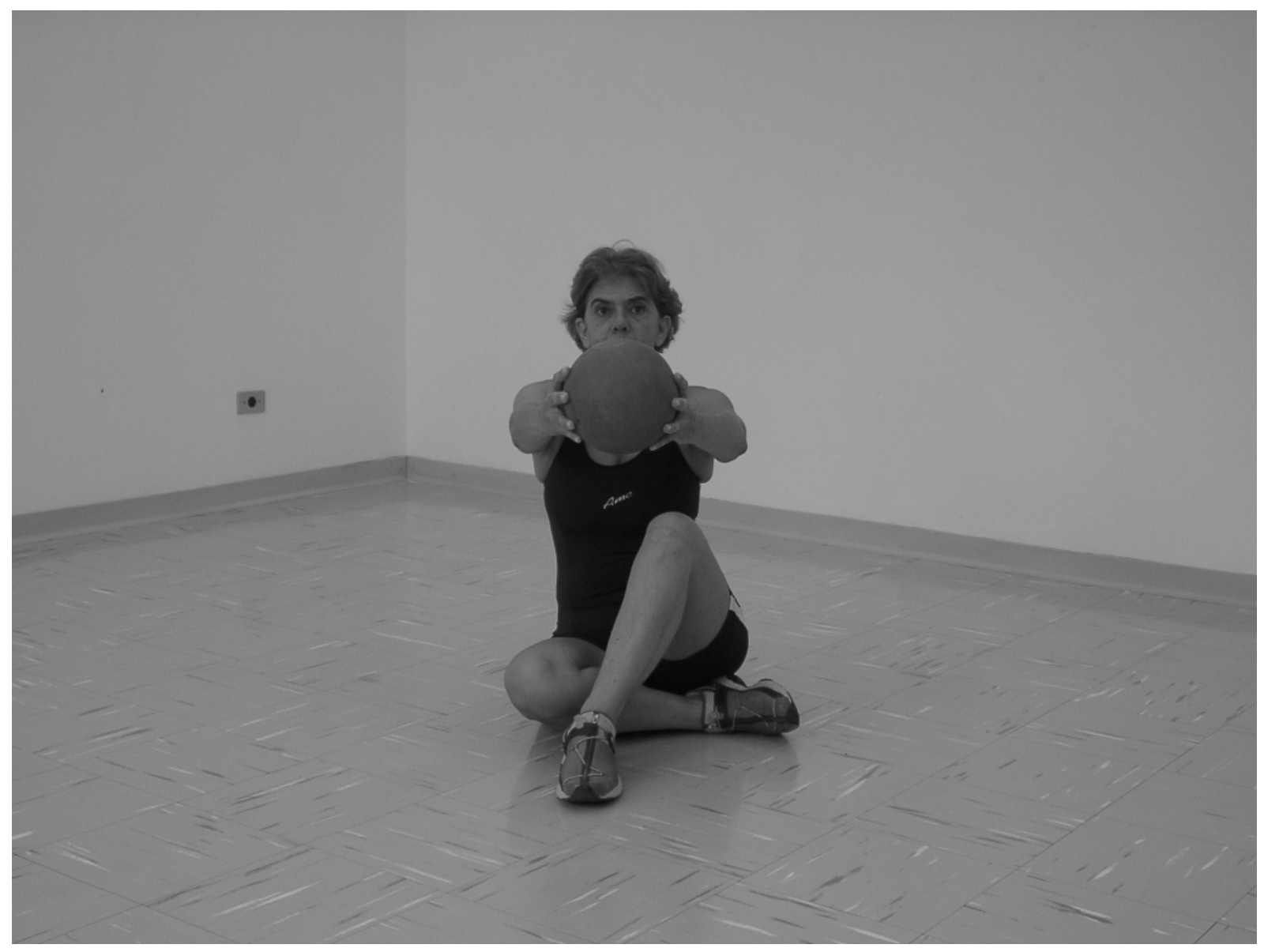




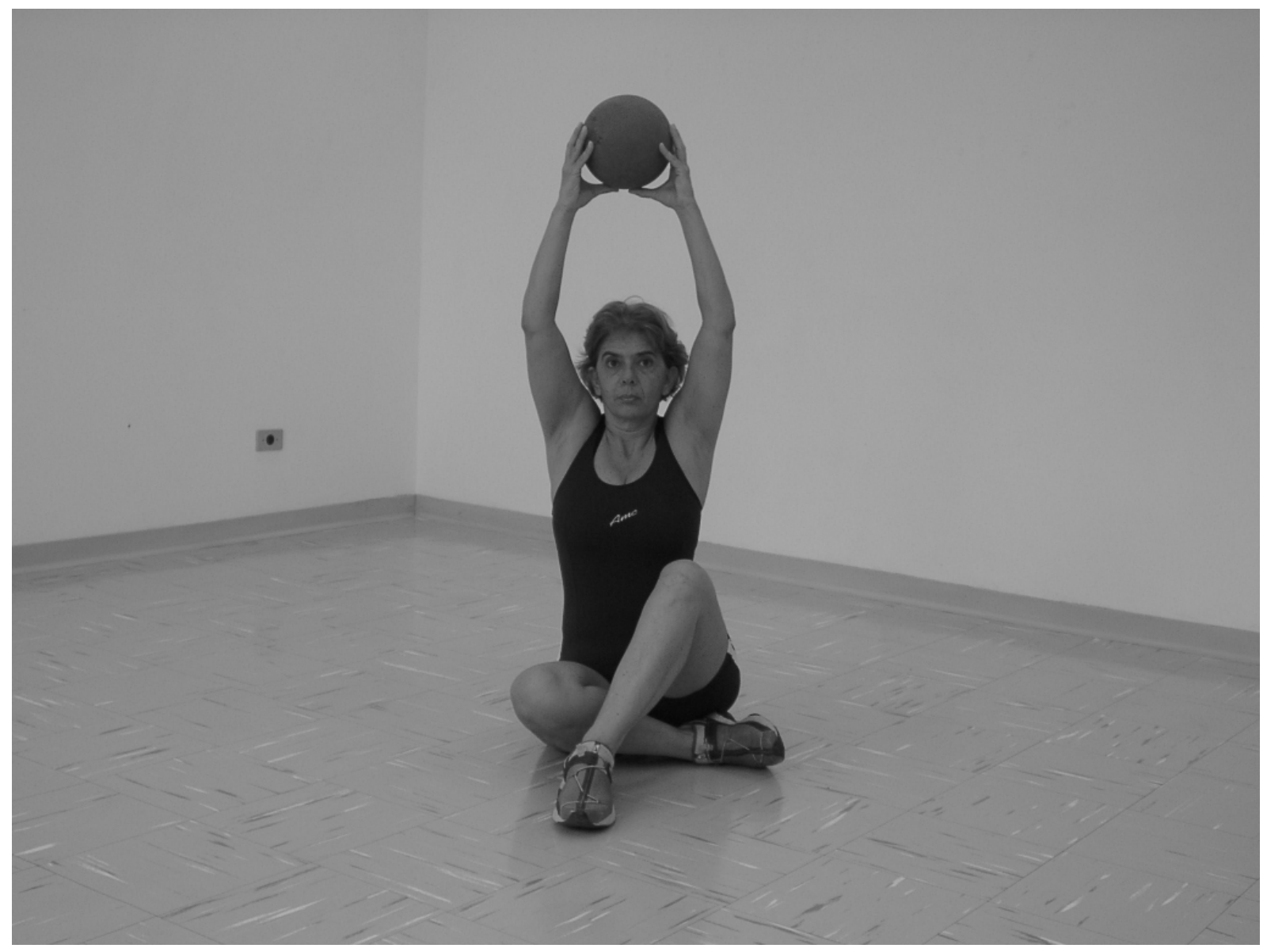




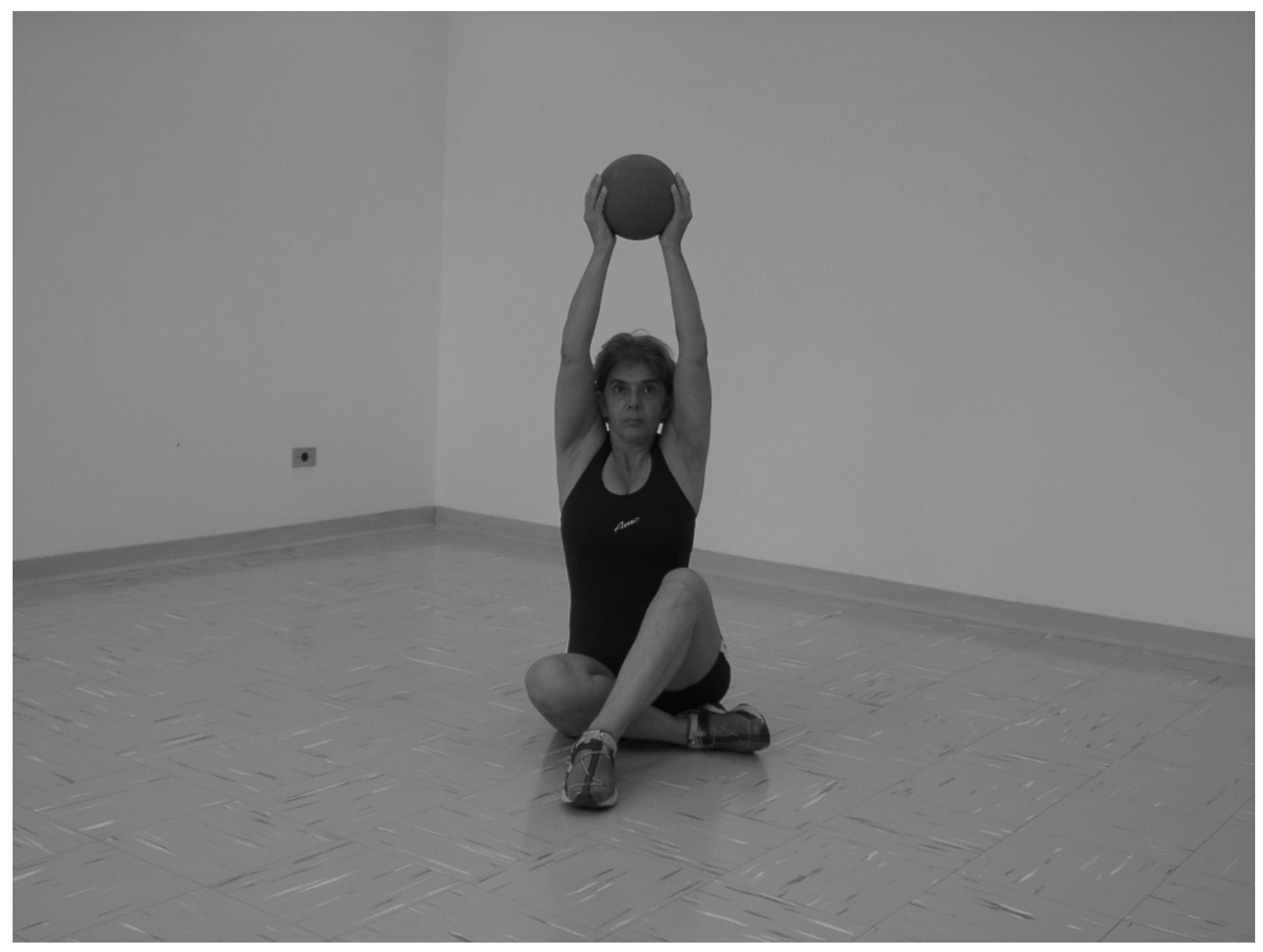




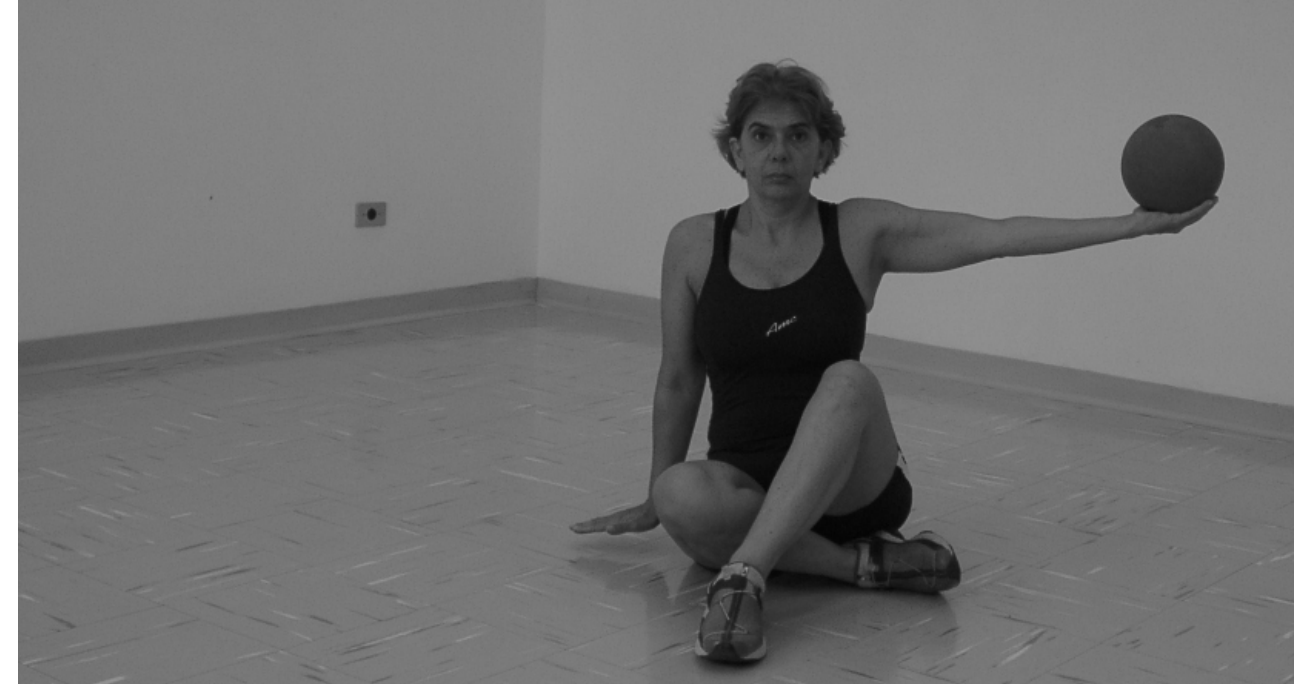





$$
8
$$




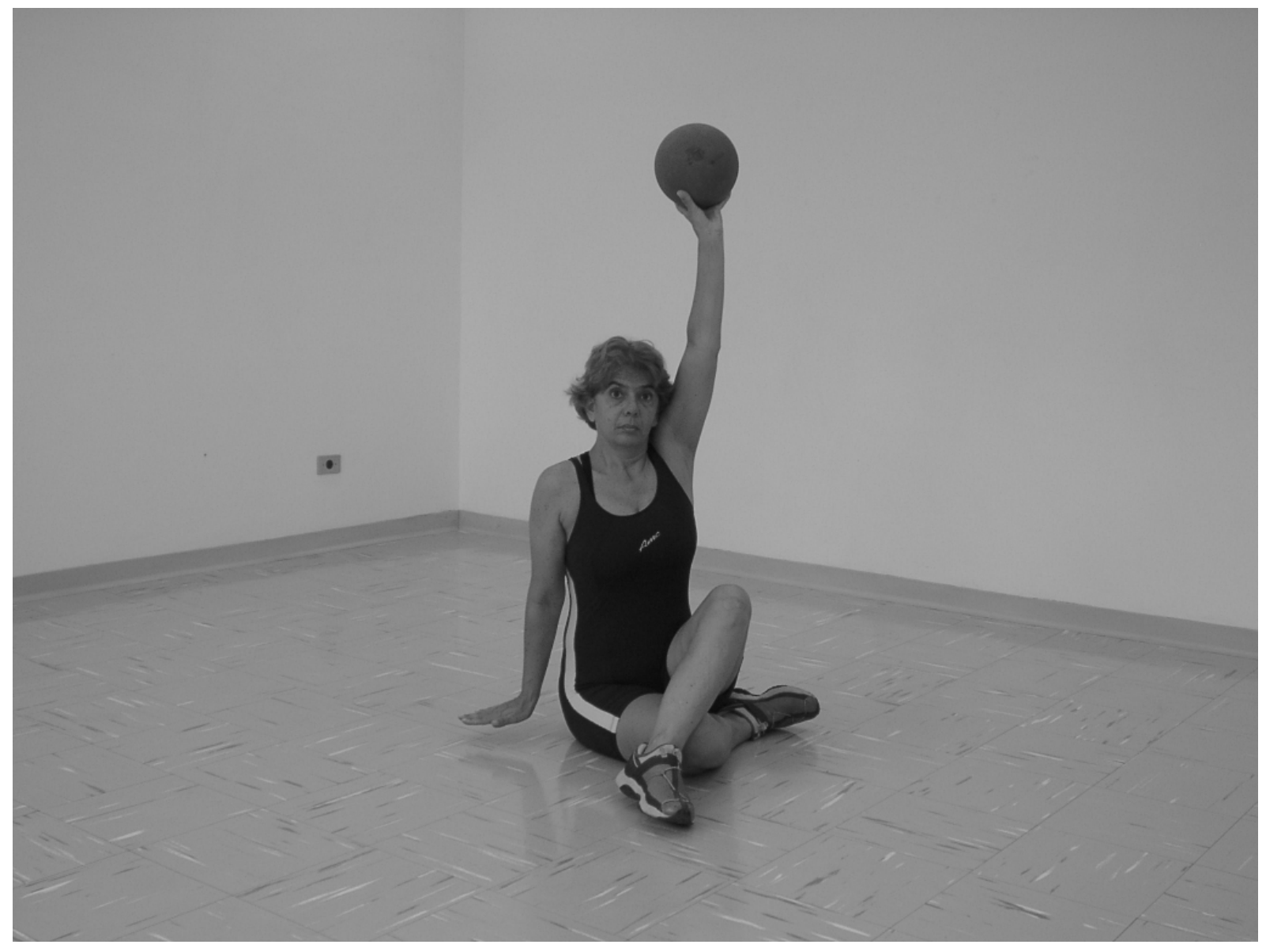




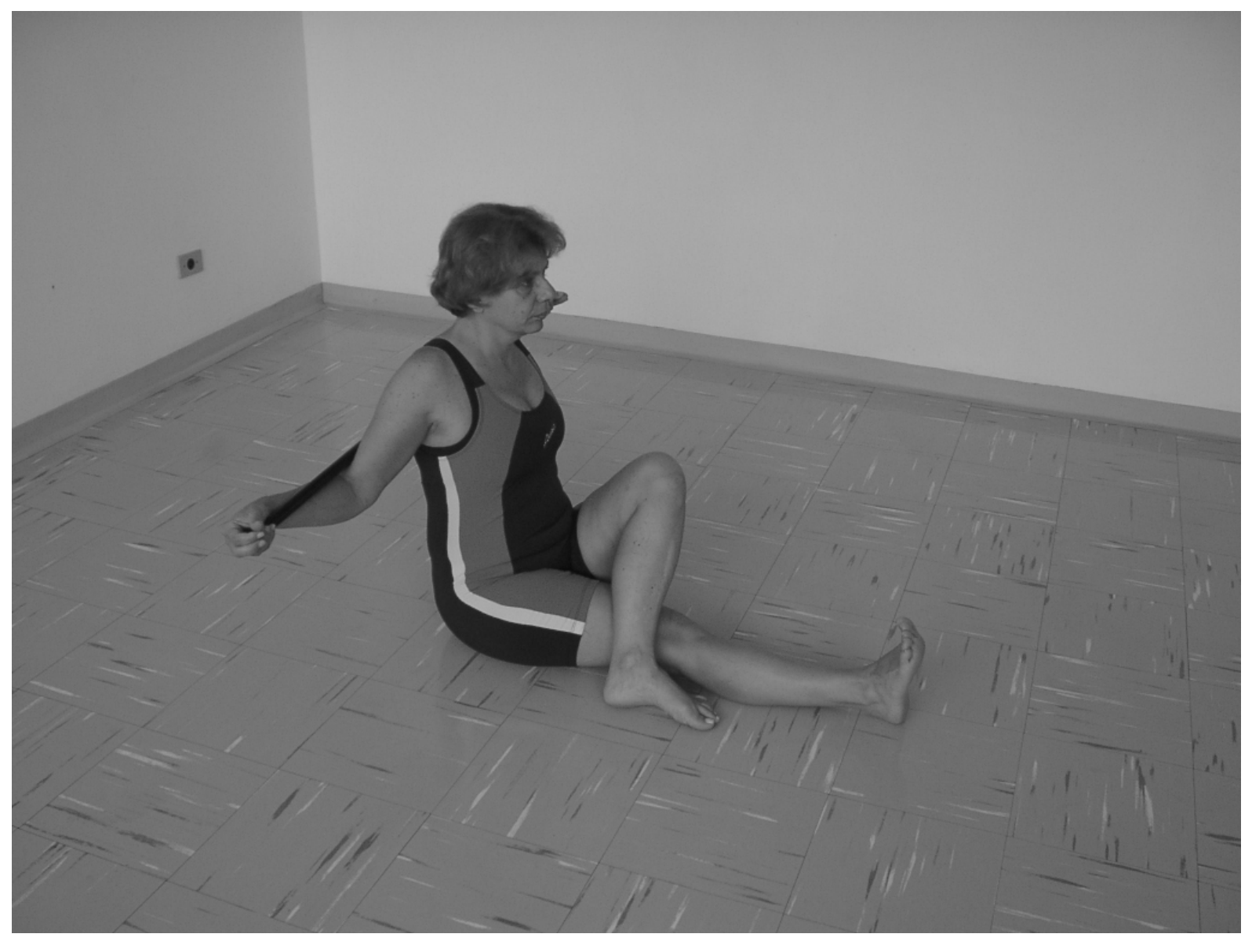


SEXTA SEMANA 


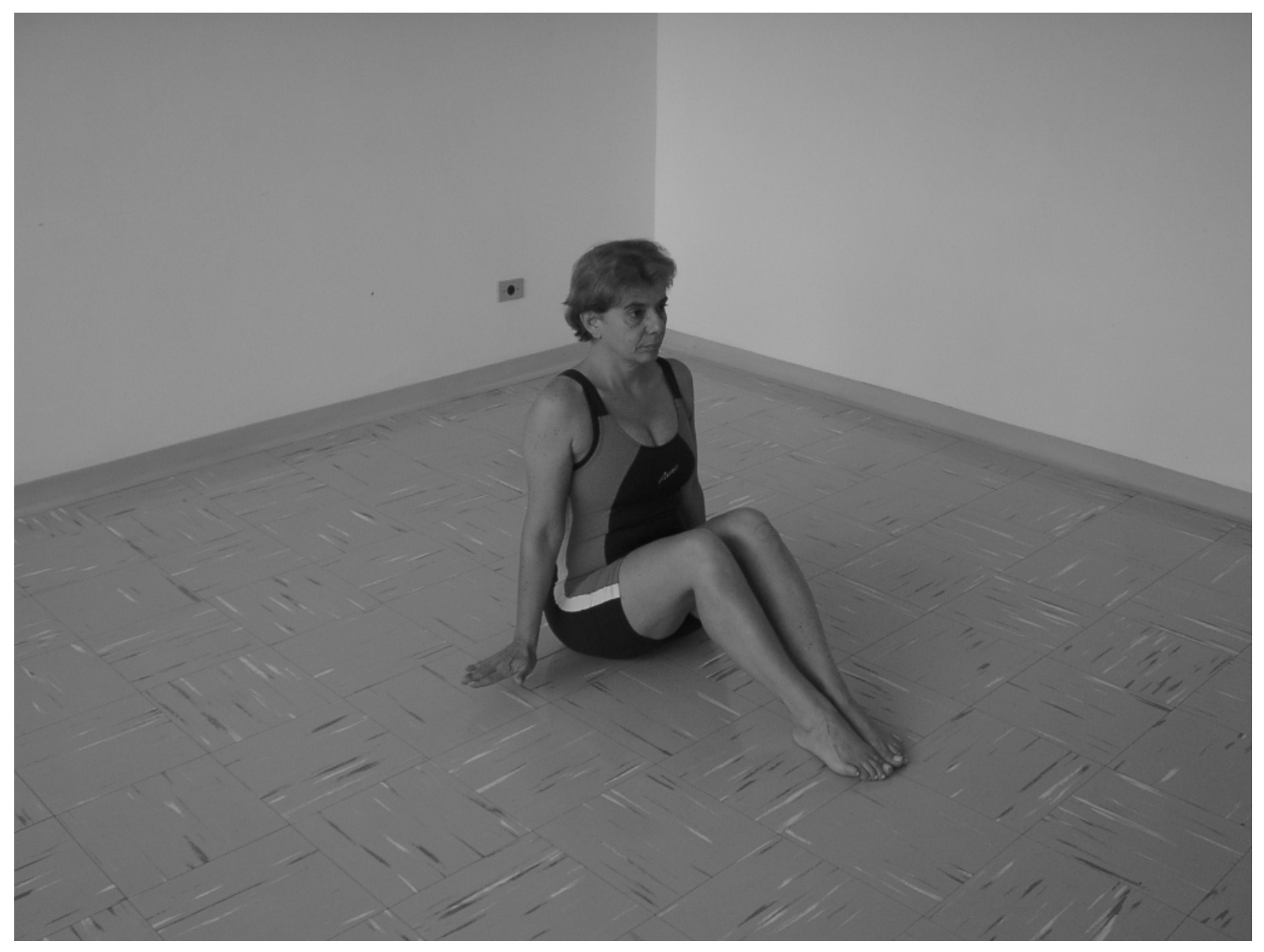




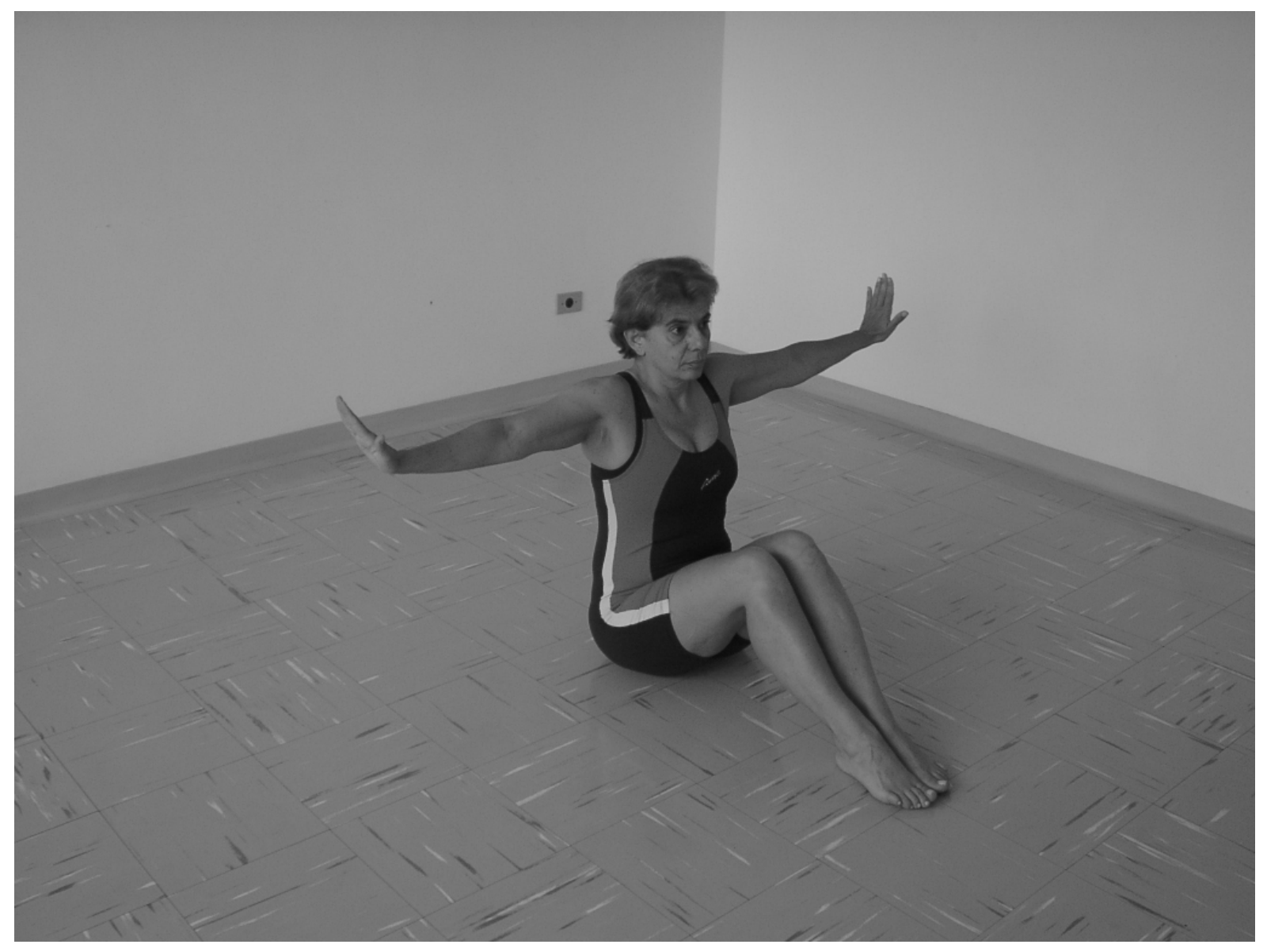




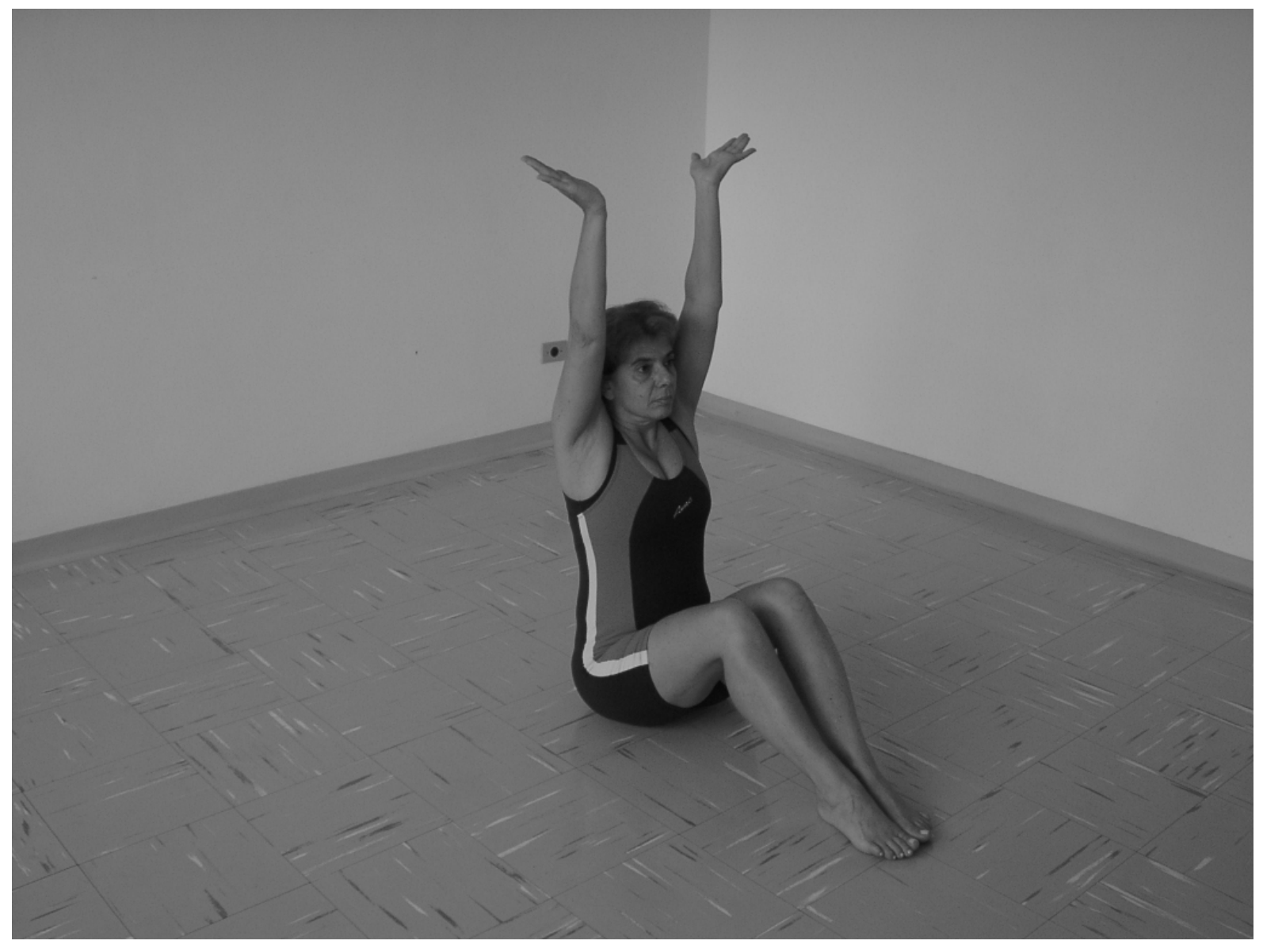





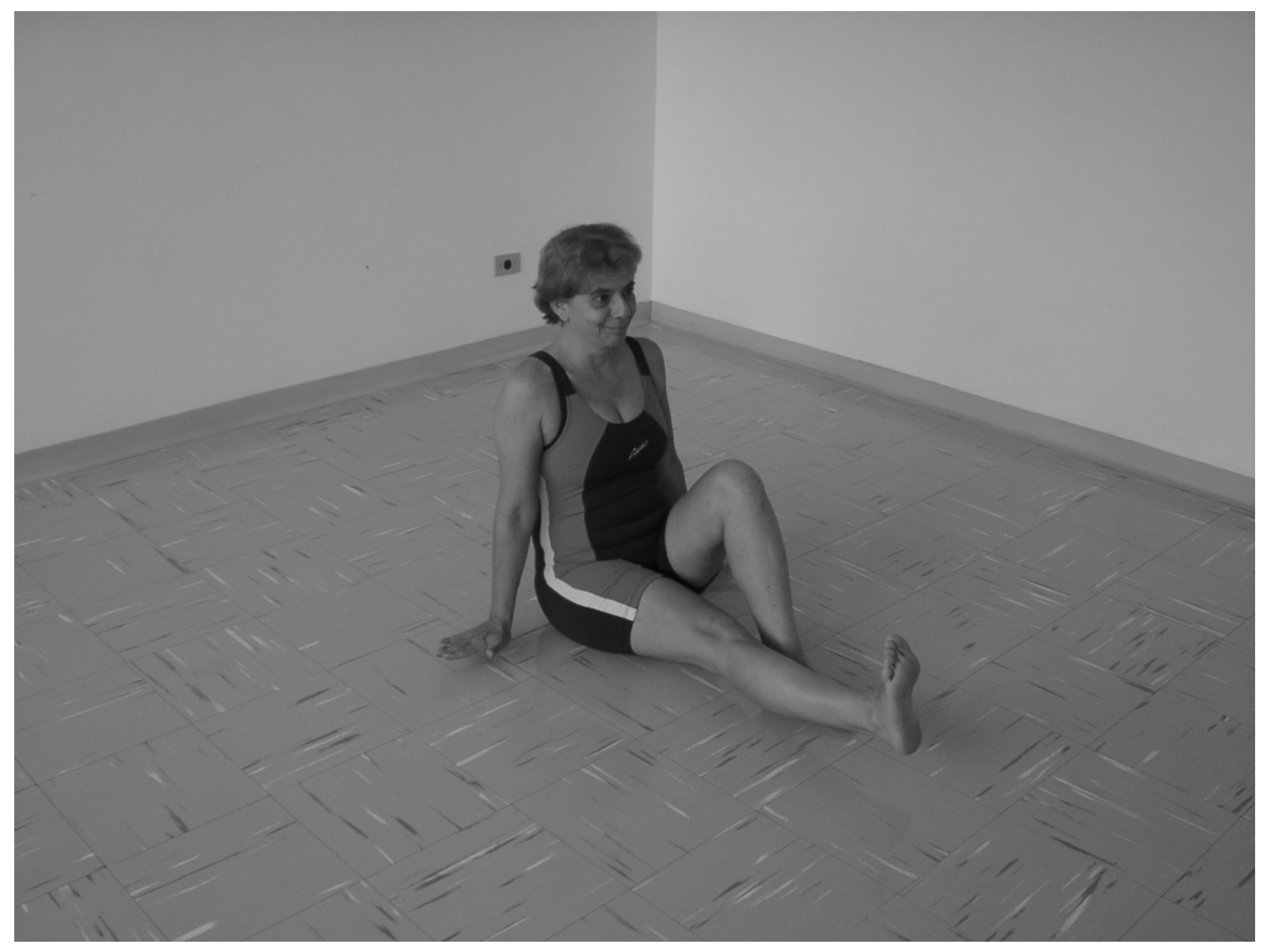




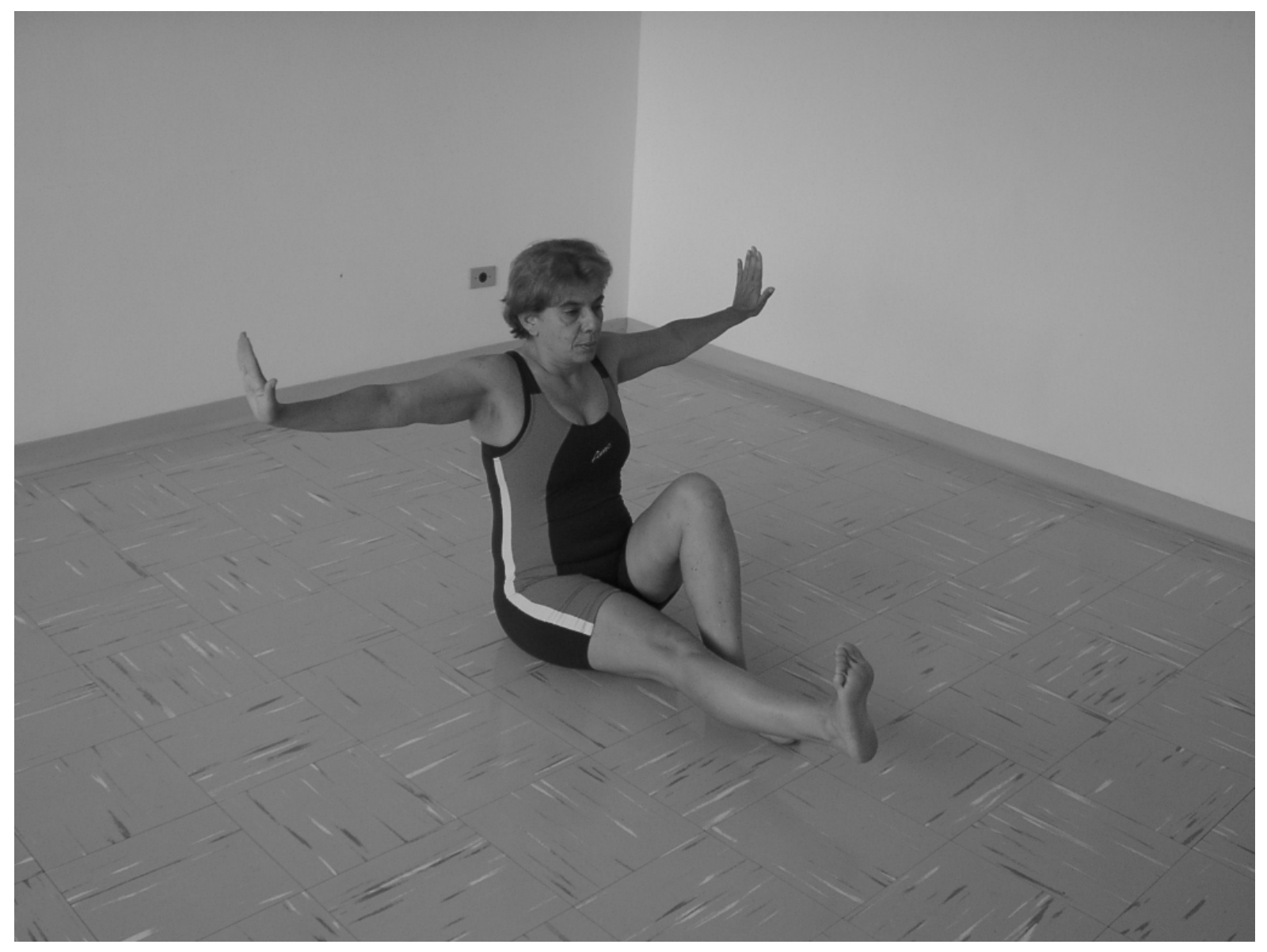




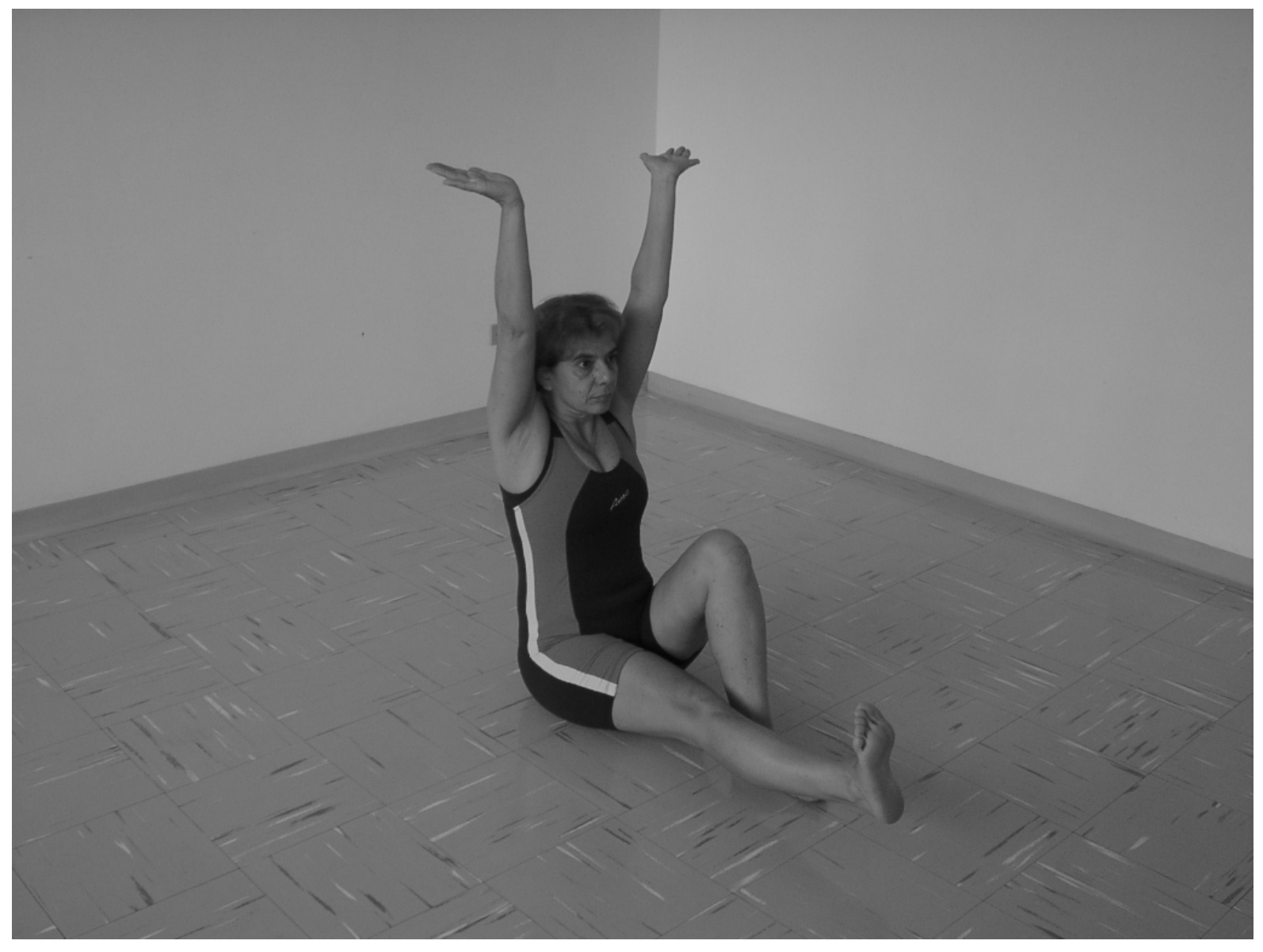




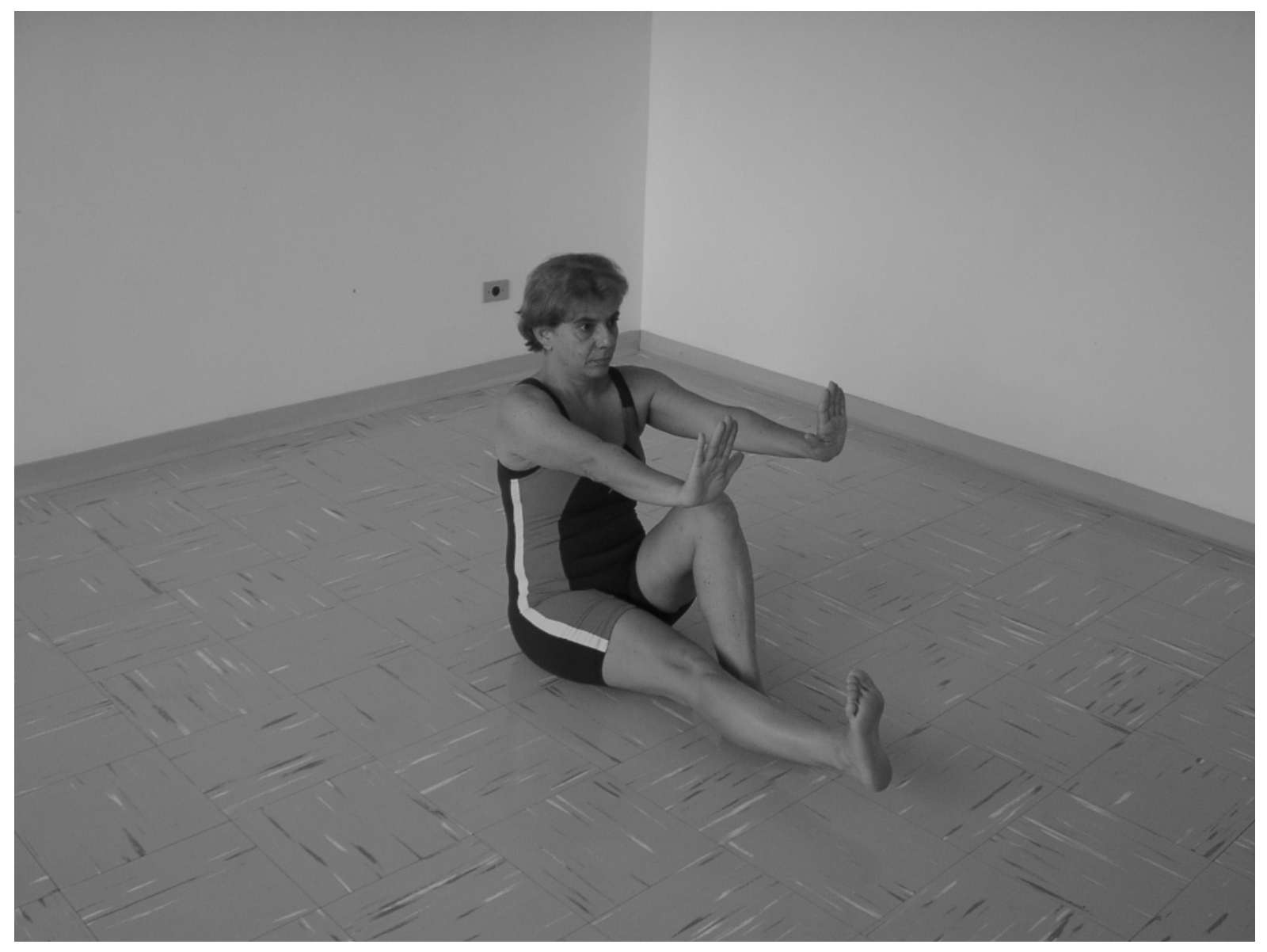




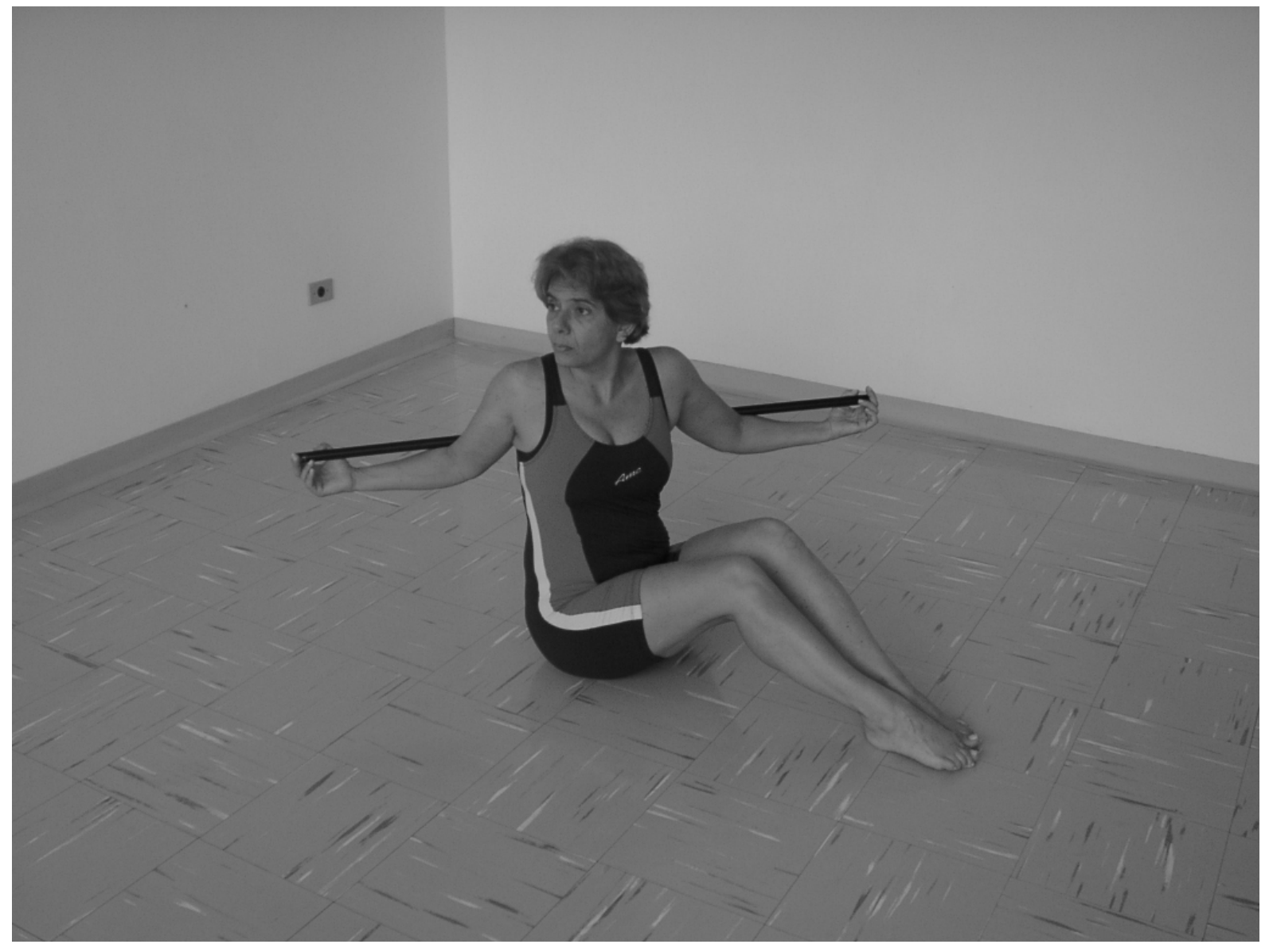


2 



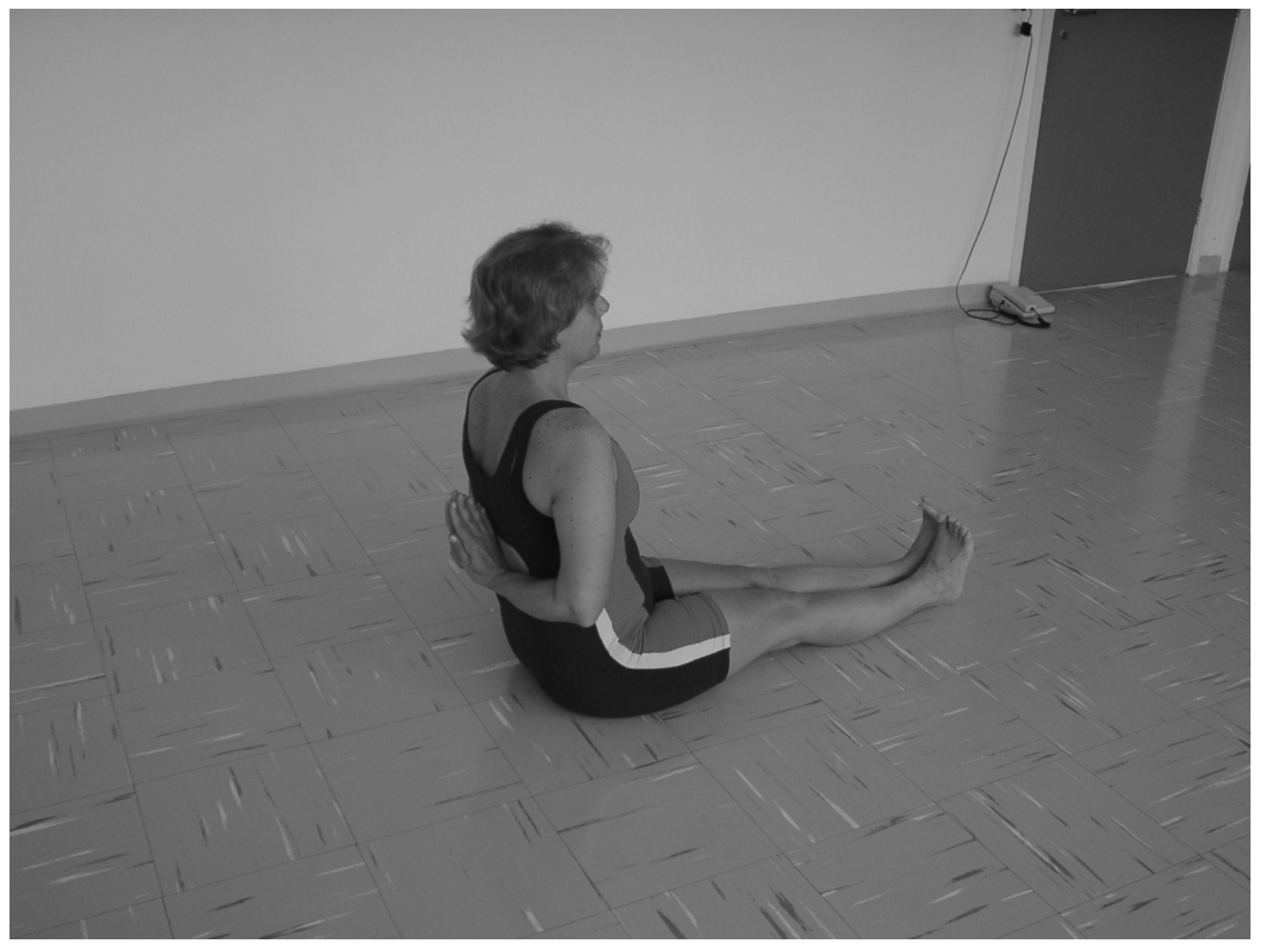




$$
\varepsilon
$$





\section{SÉTIMA SEMANA}




$$
\text { \& }
$$




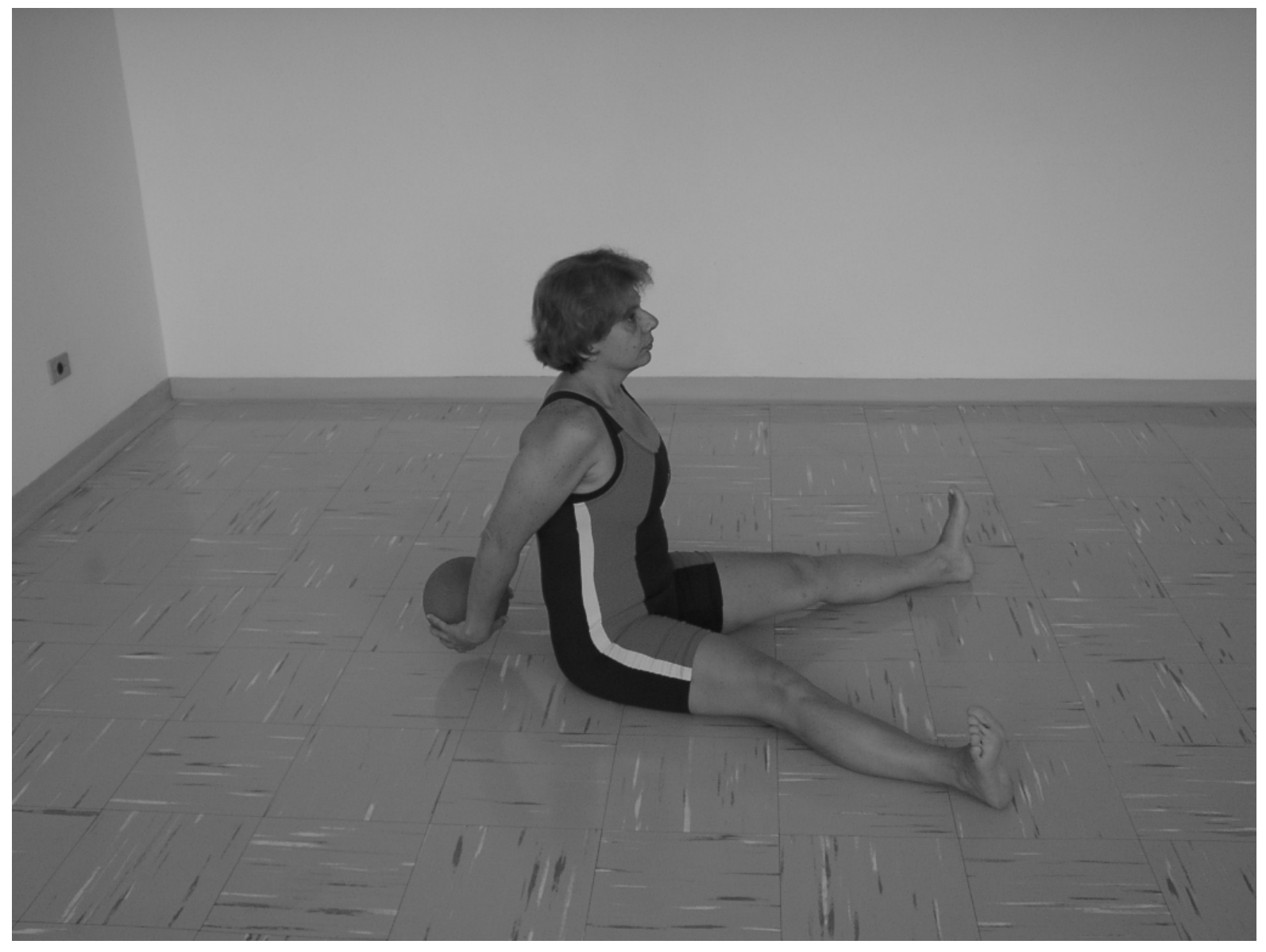




$$
\&
$$




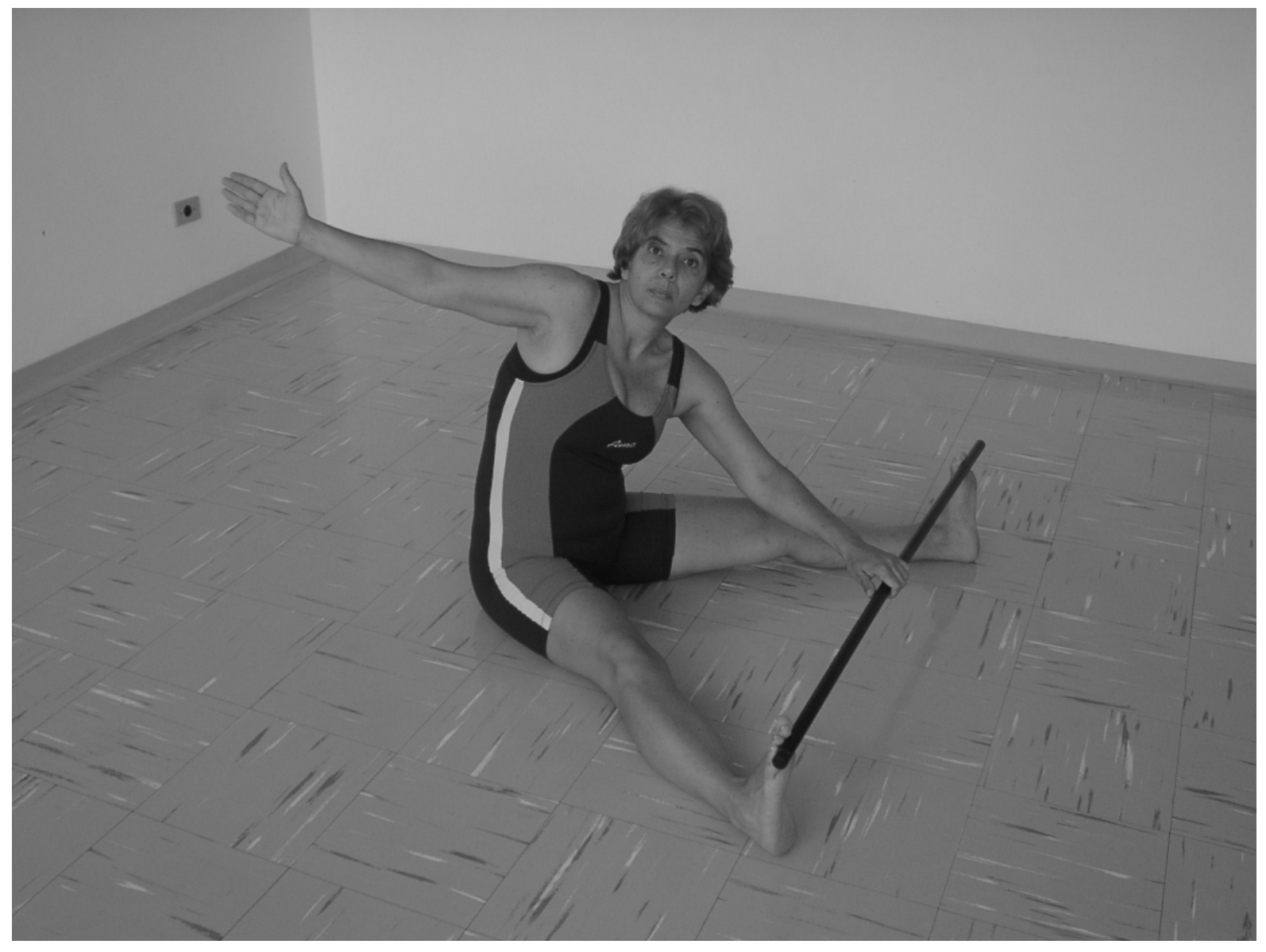




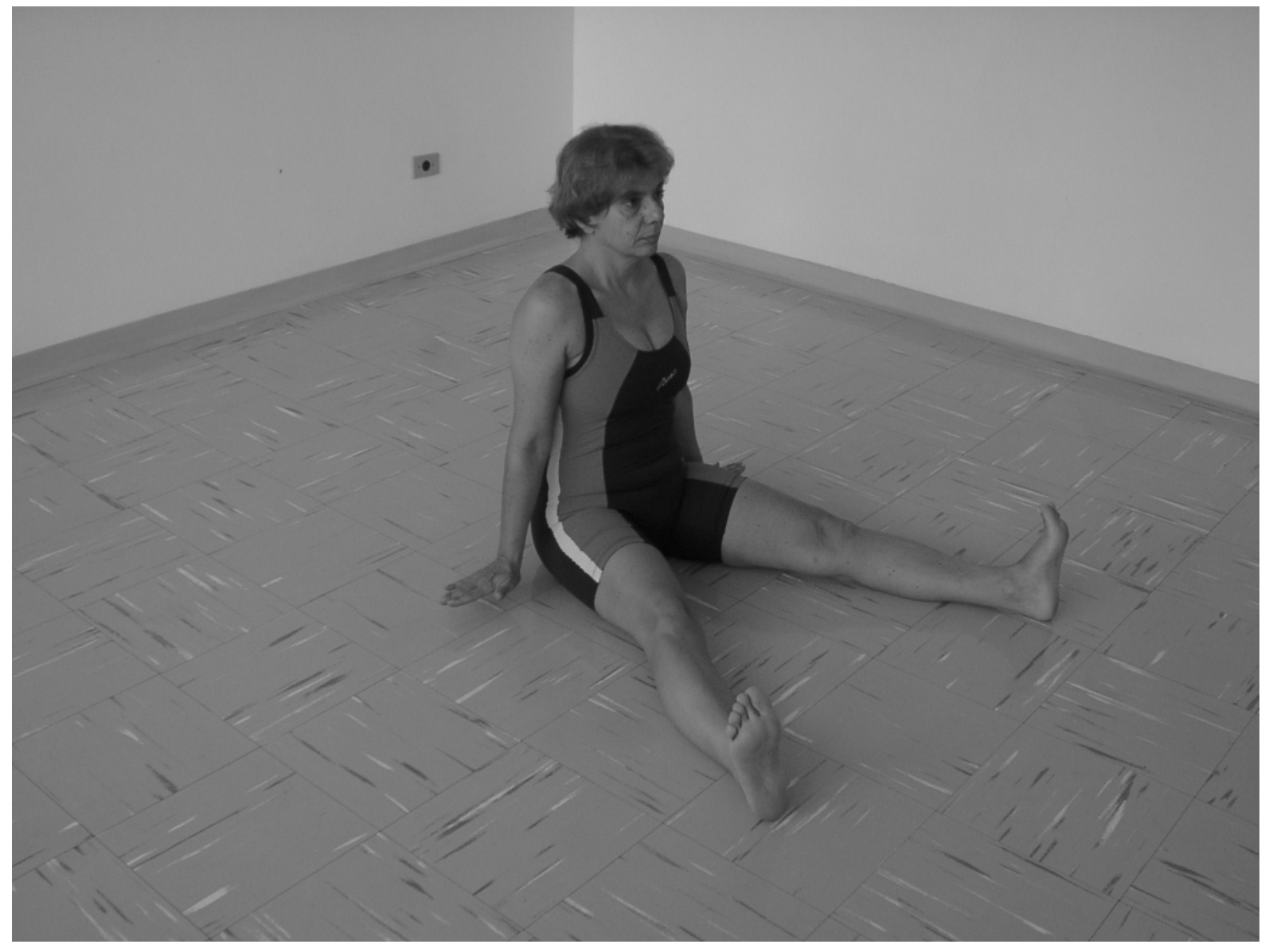




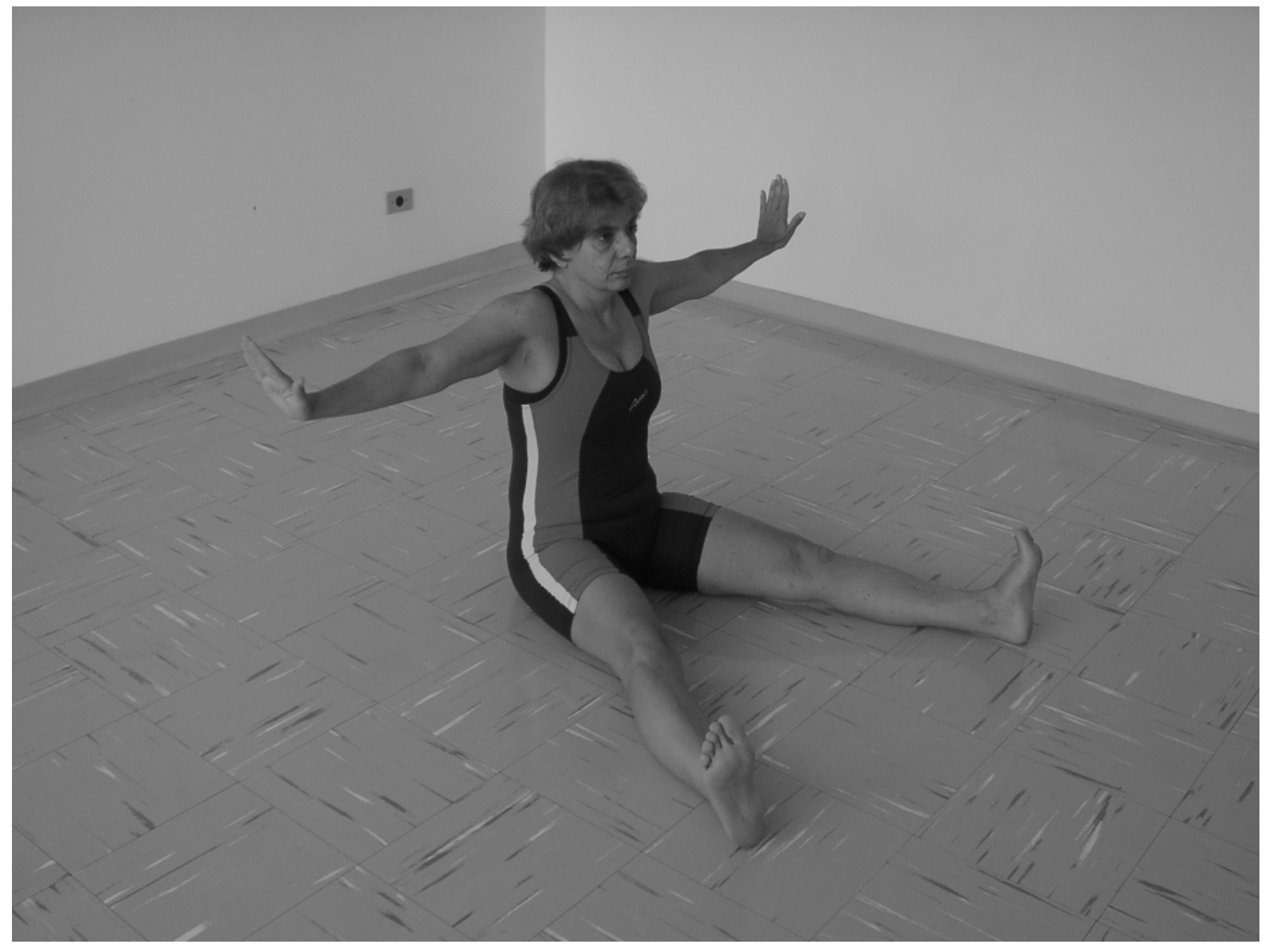




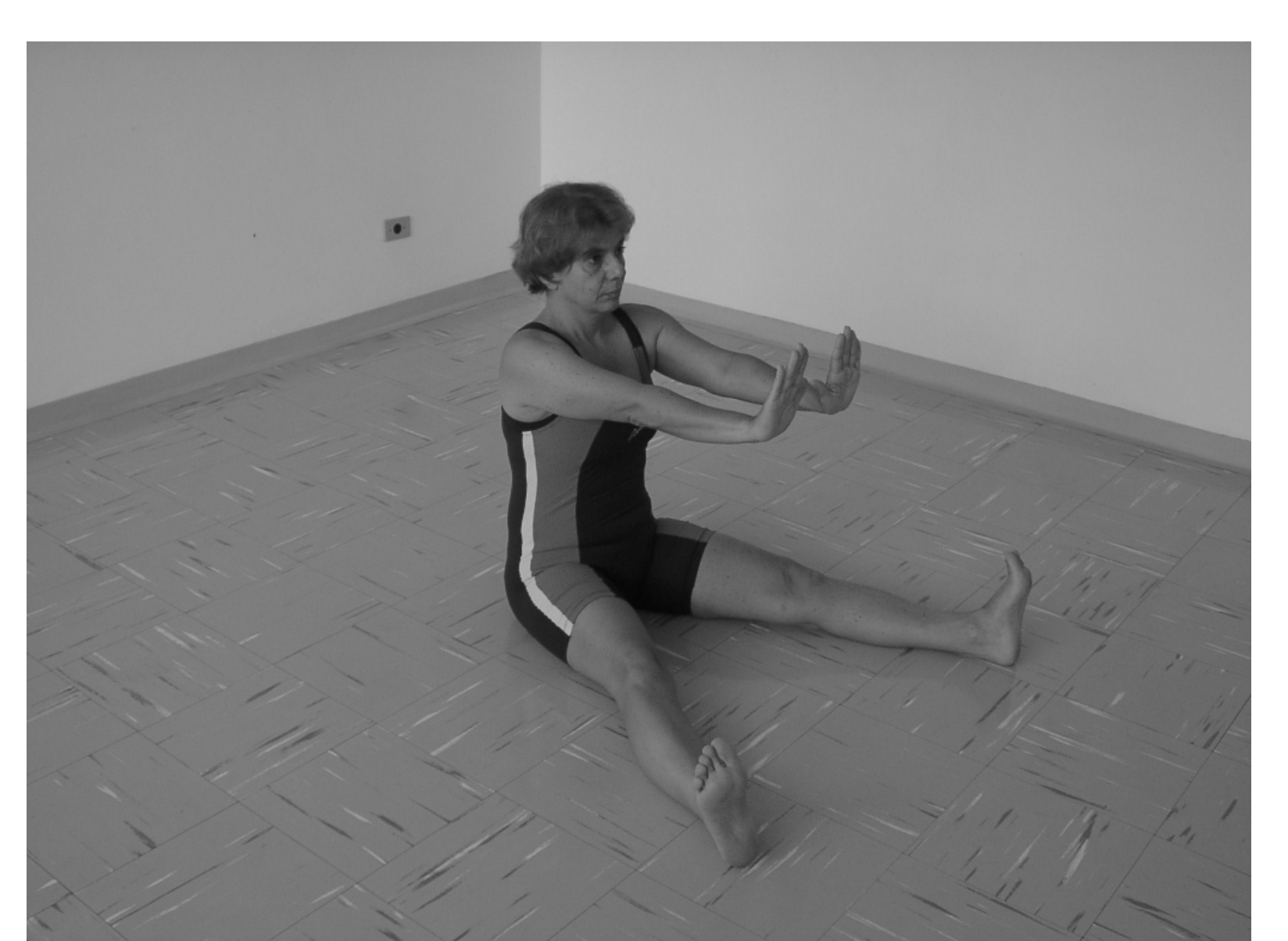




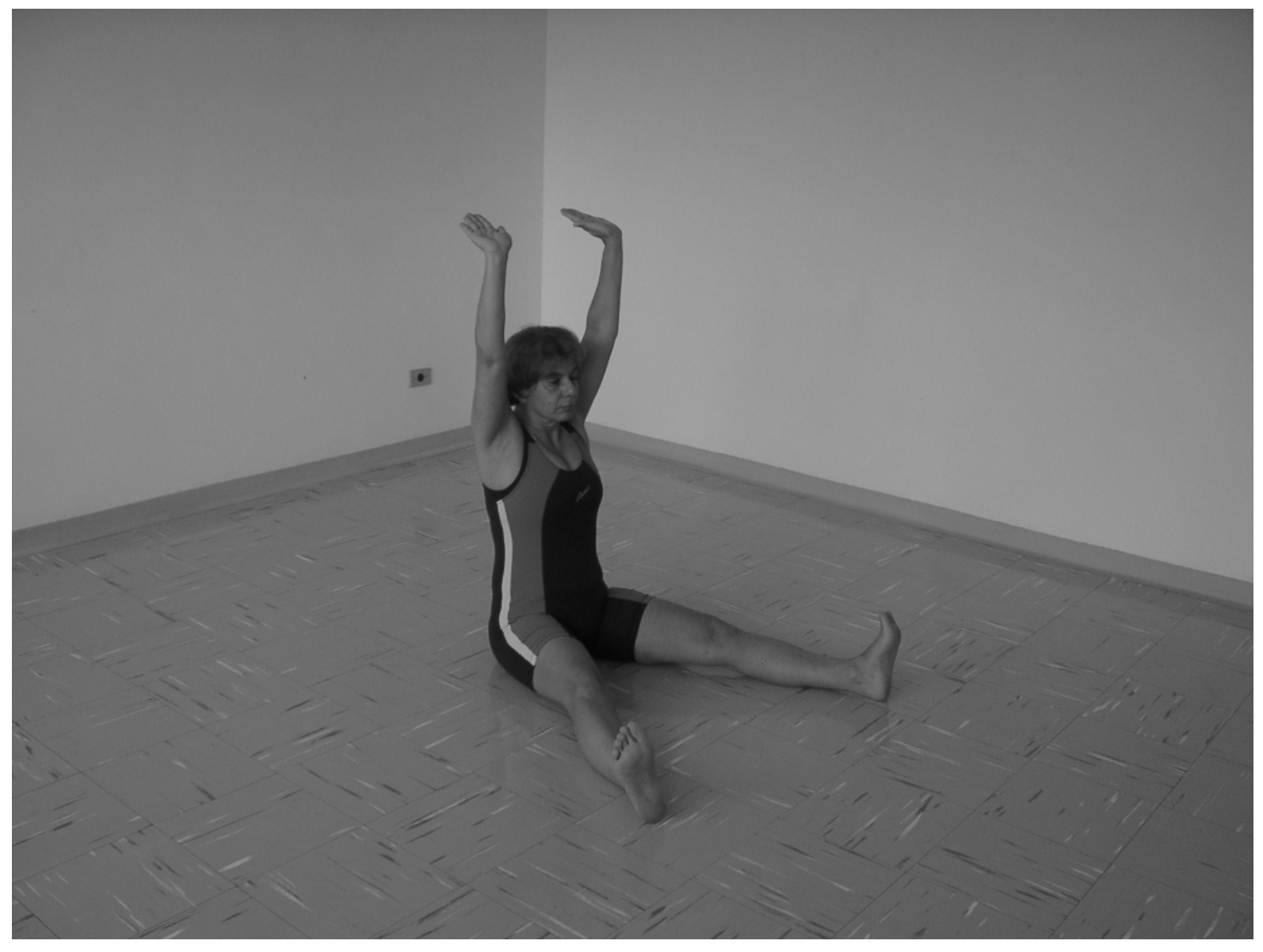





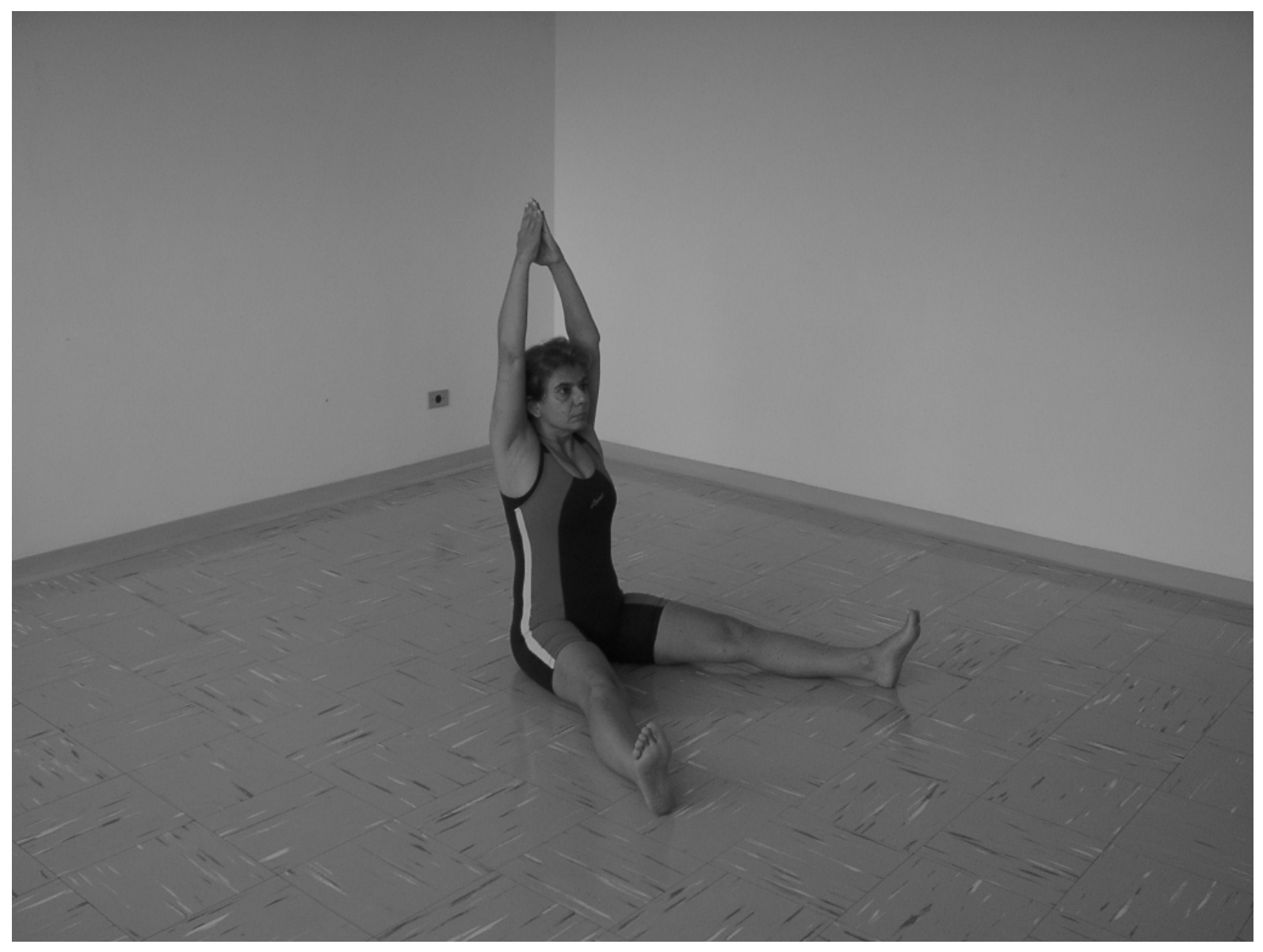





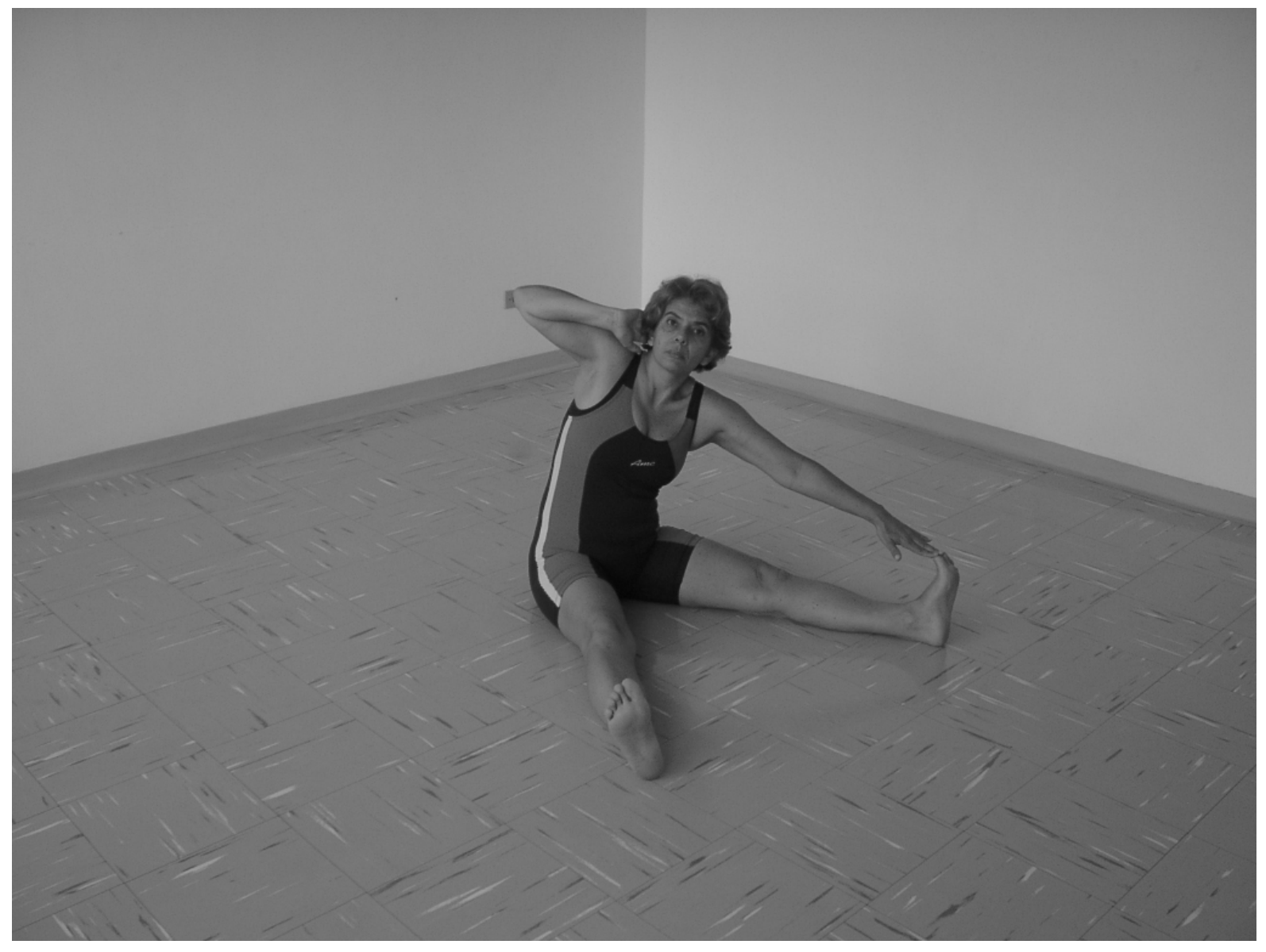




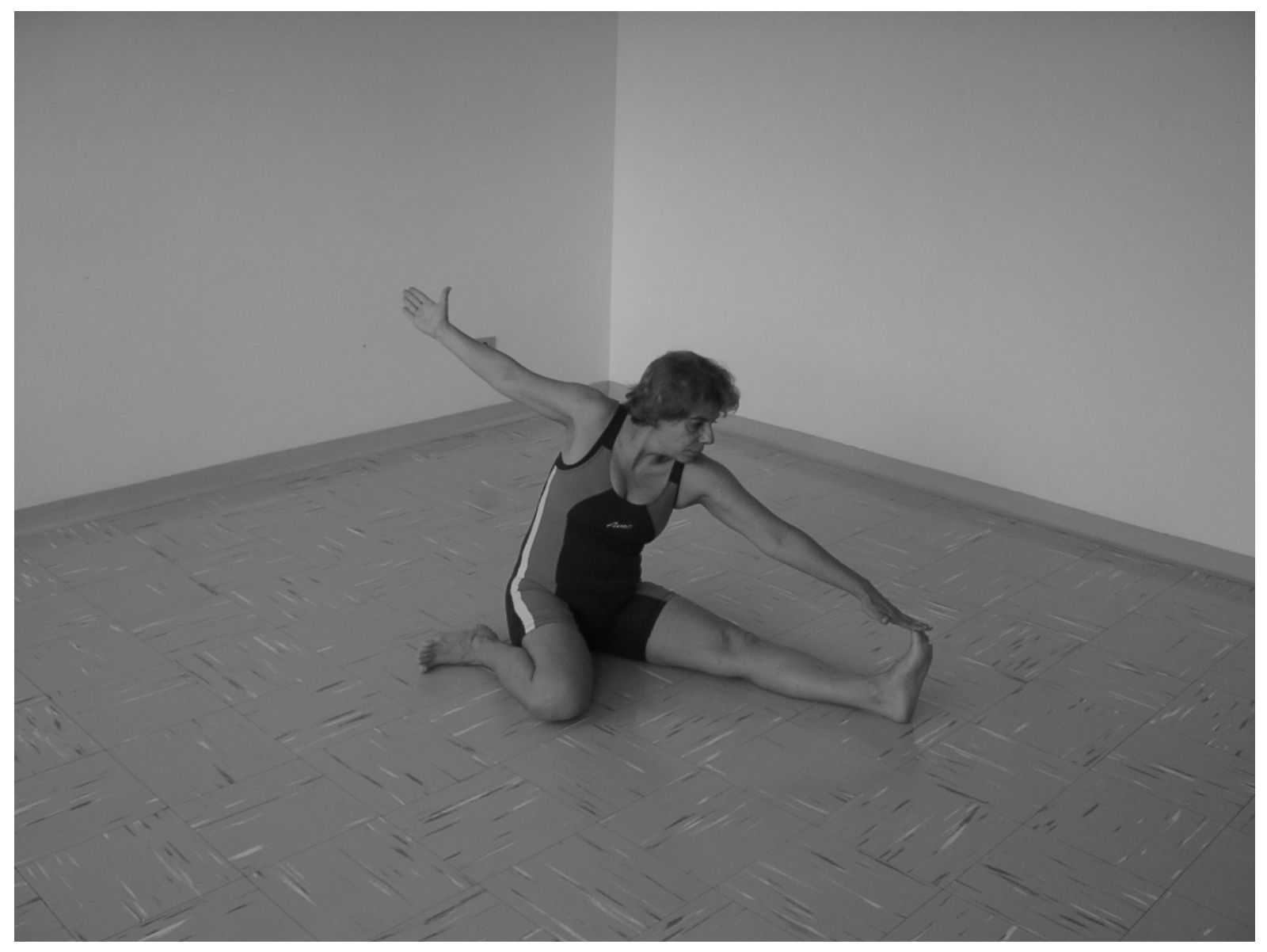




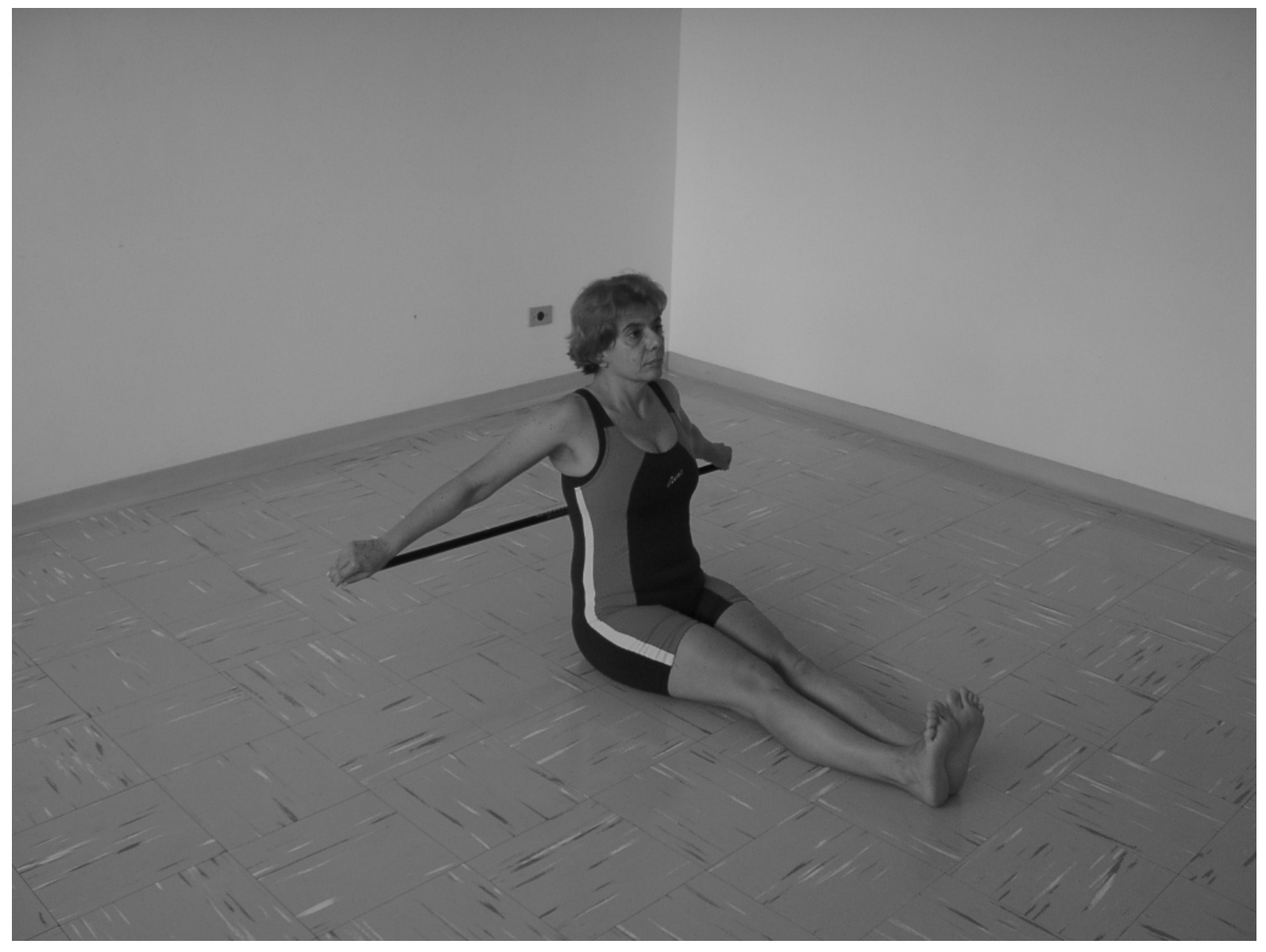




\section{OITAVA SEMANA}




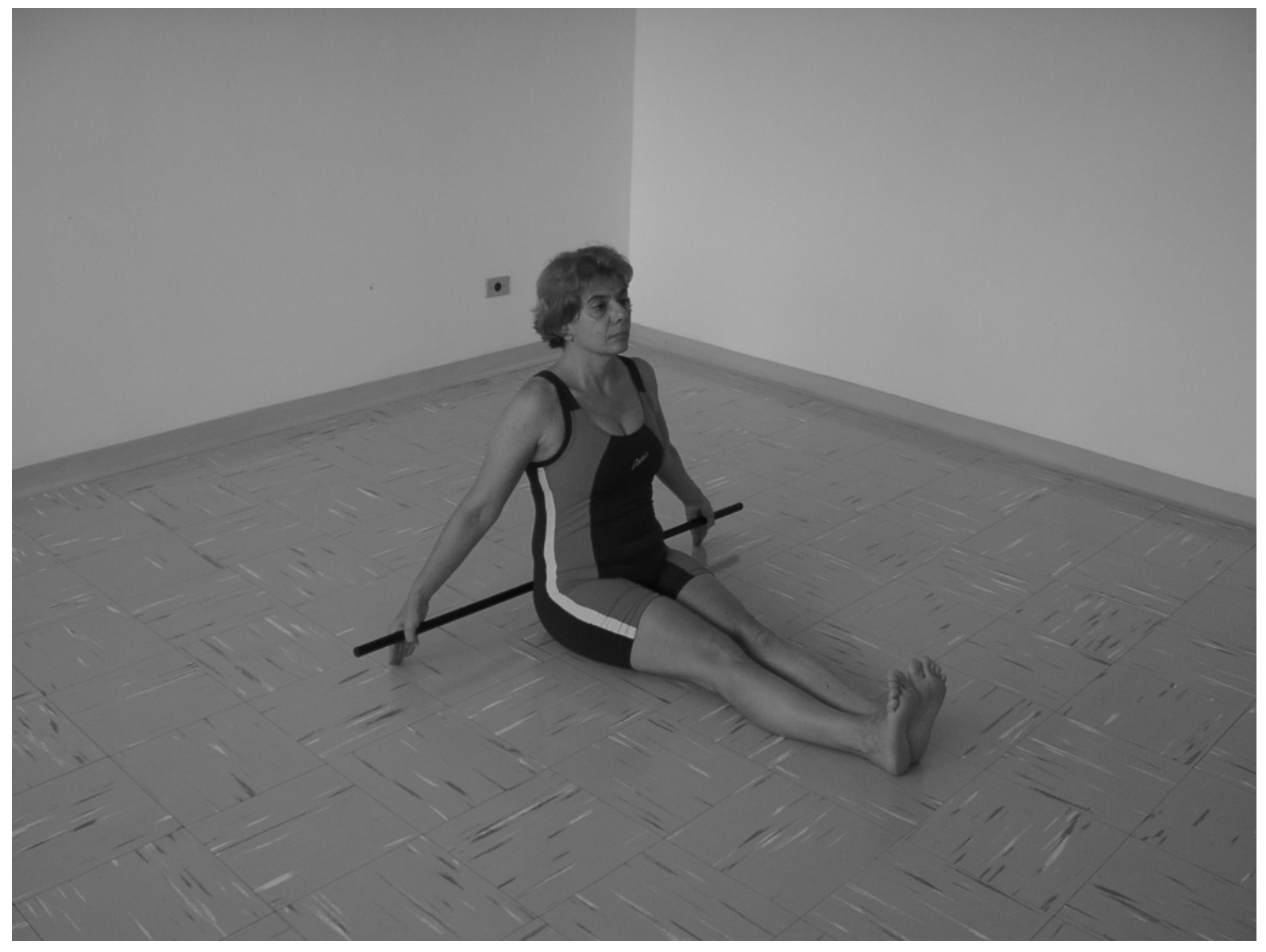





$$
\text { T }
$$





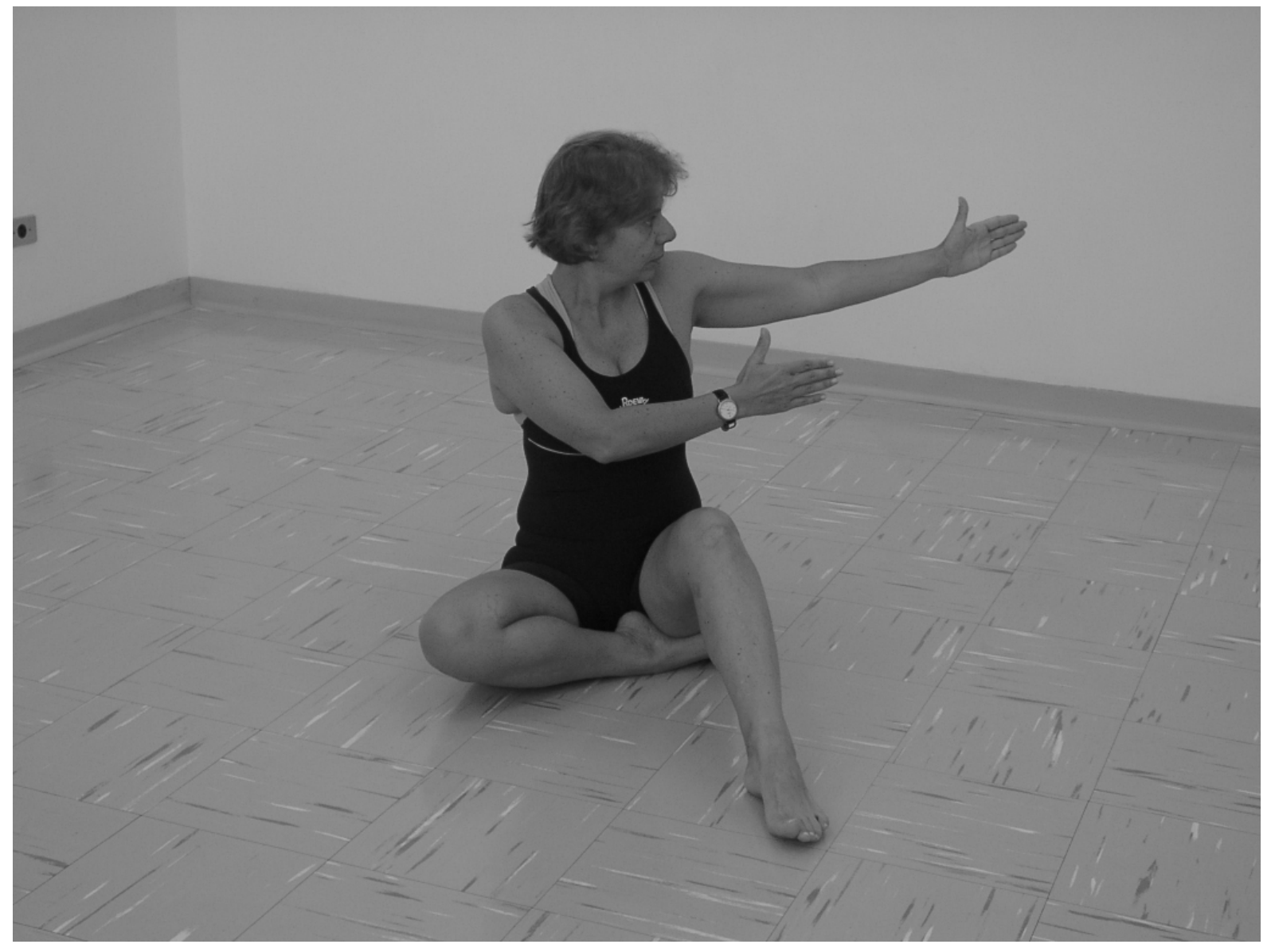




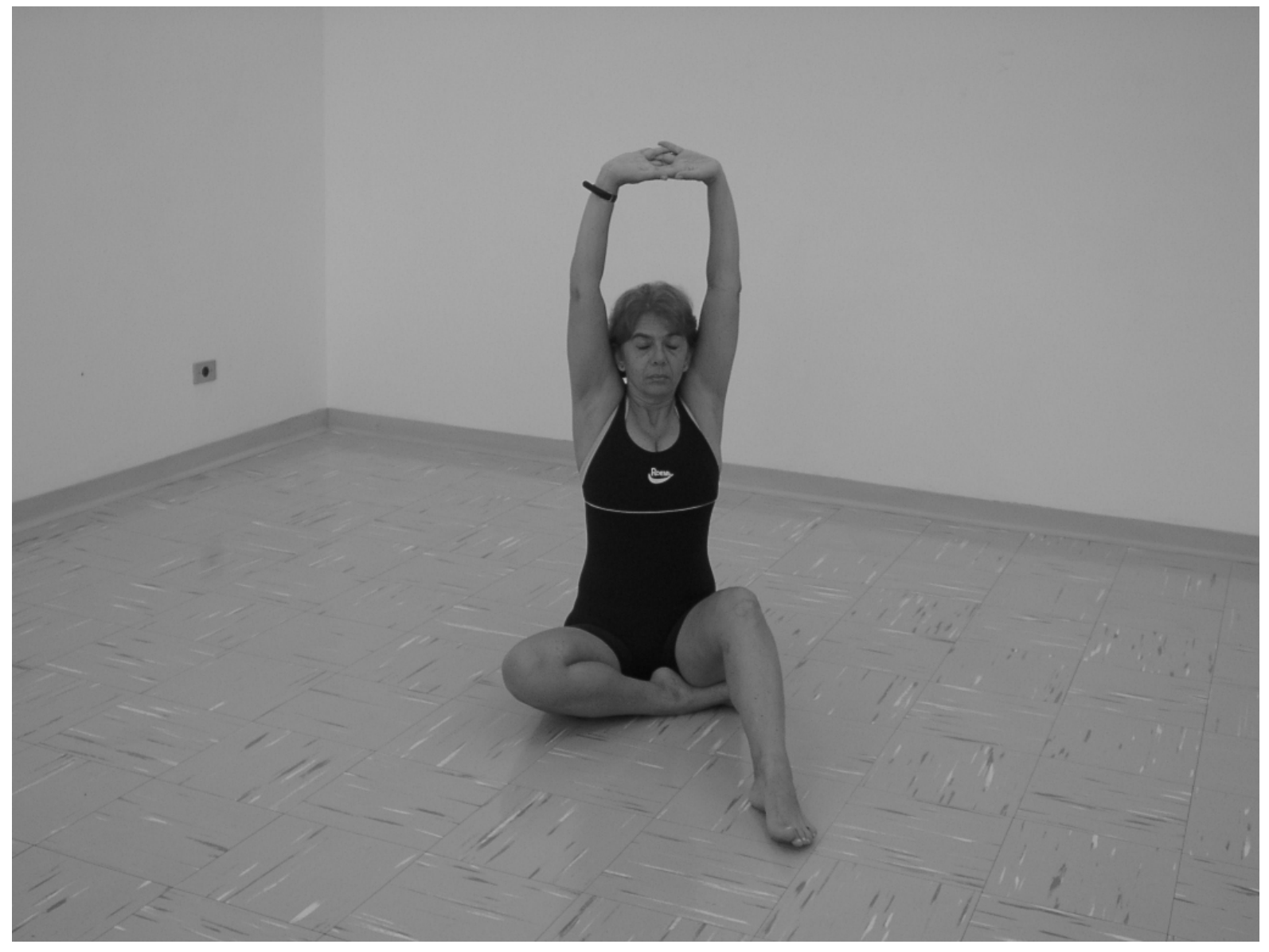




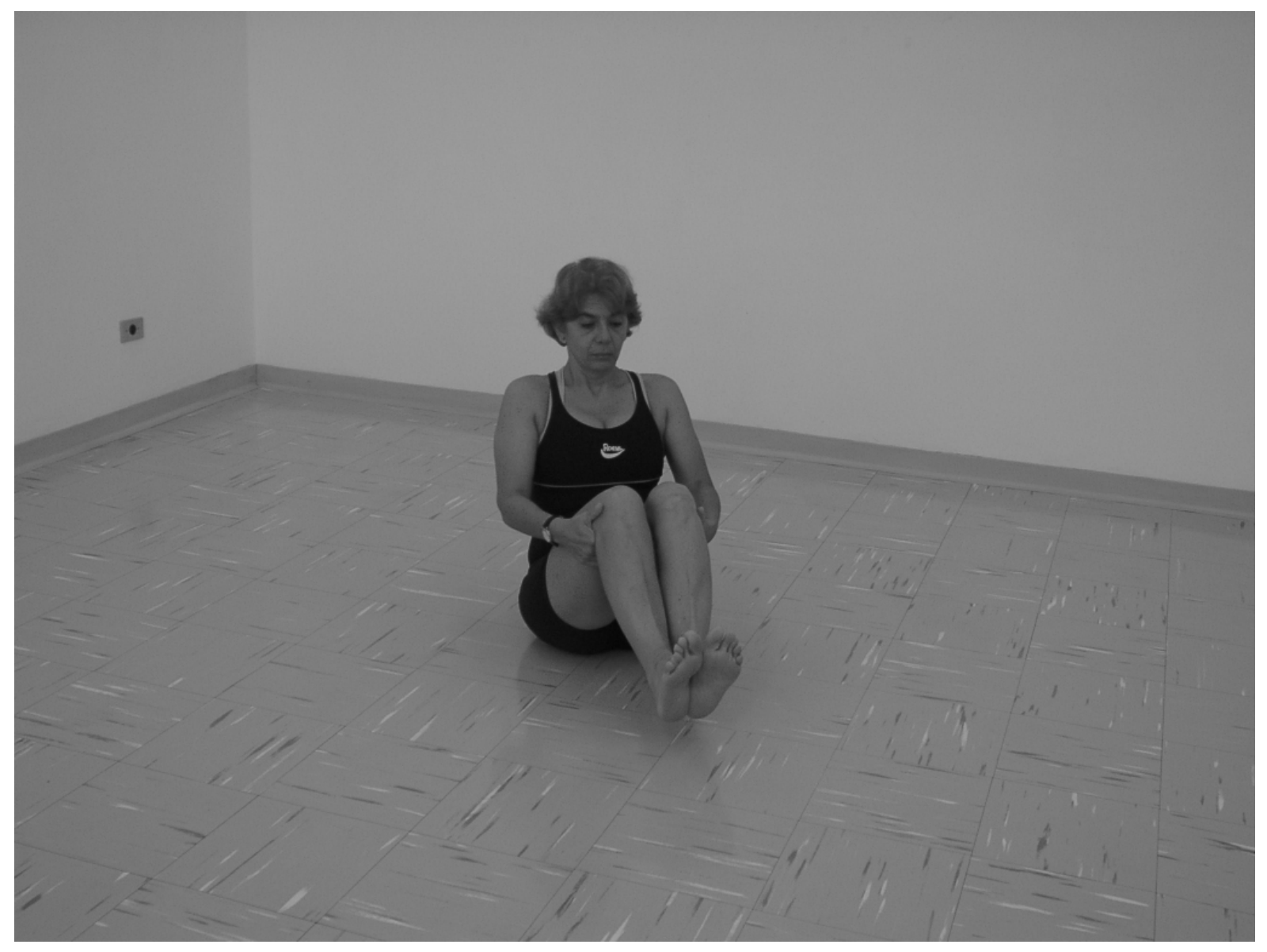




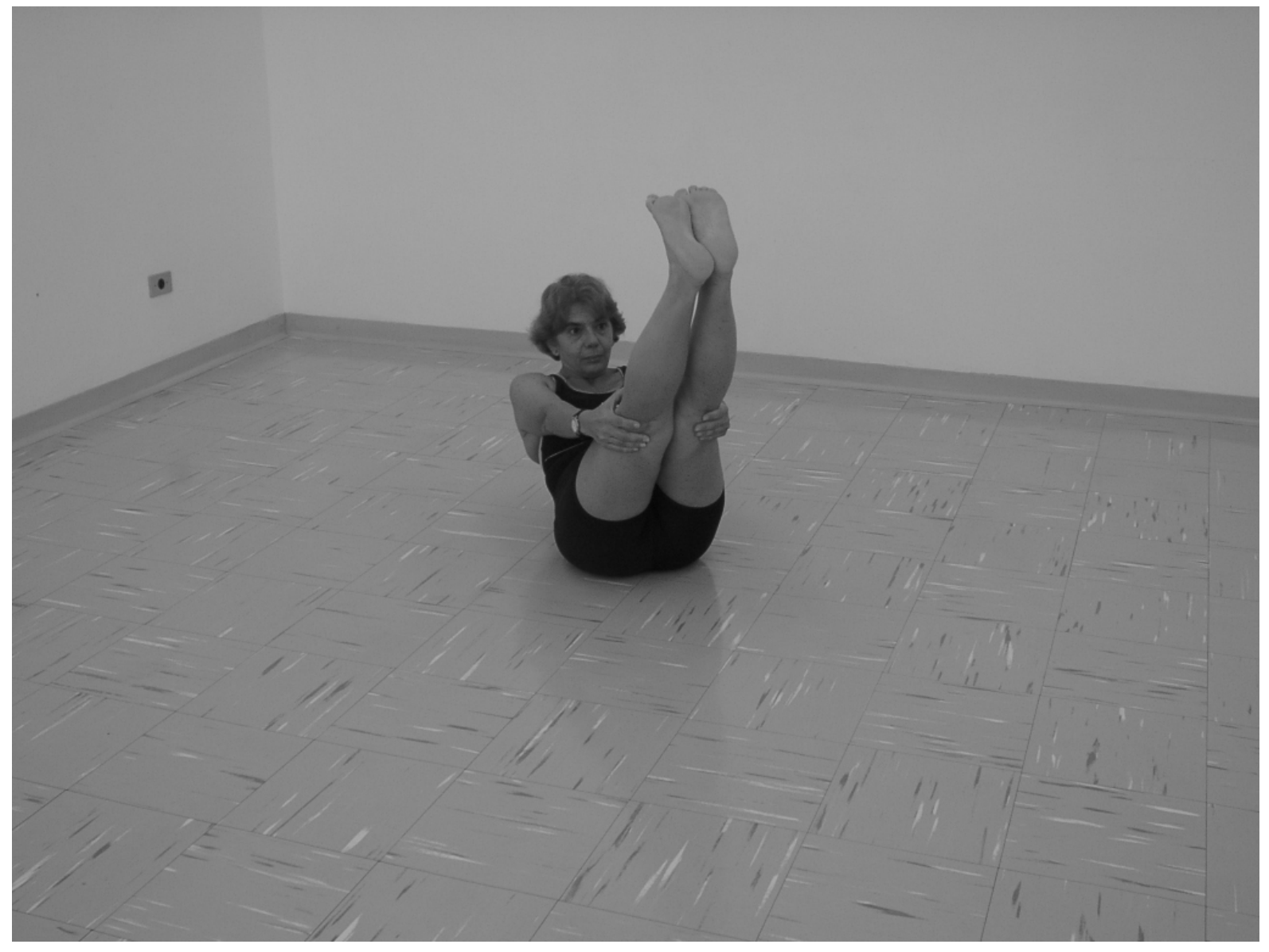




$$
v
$$




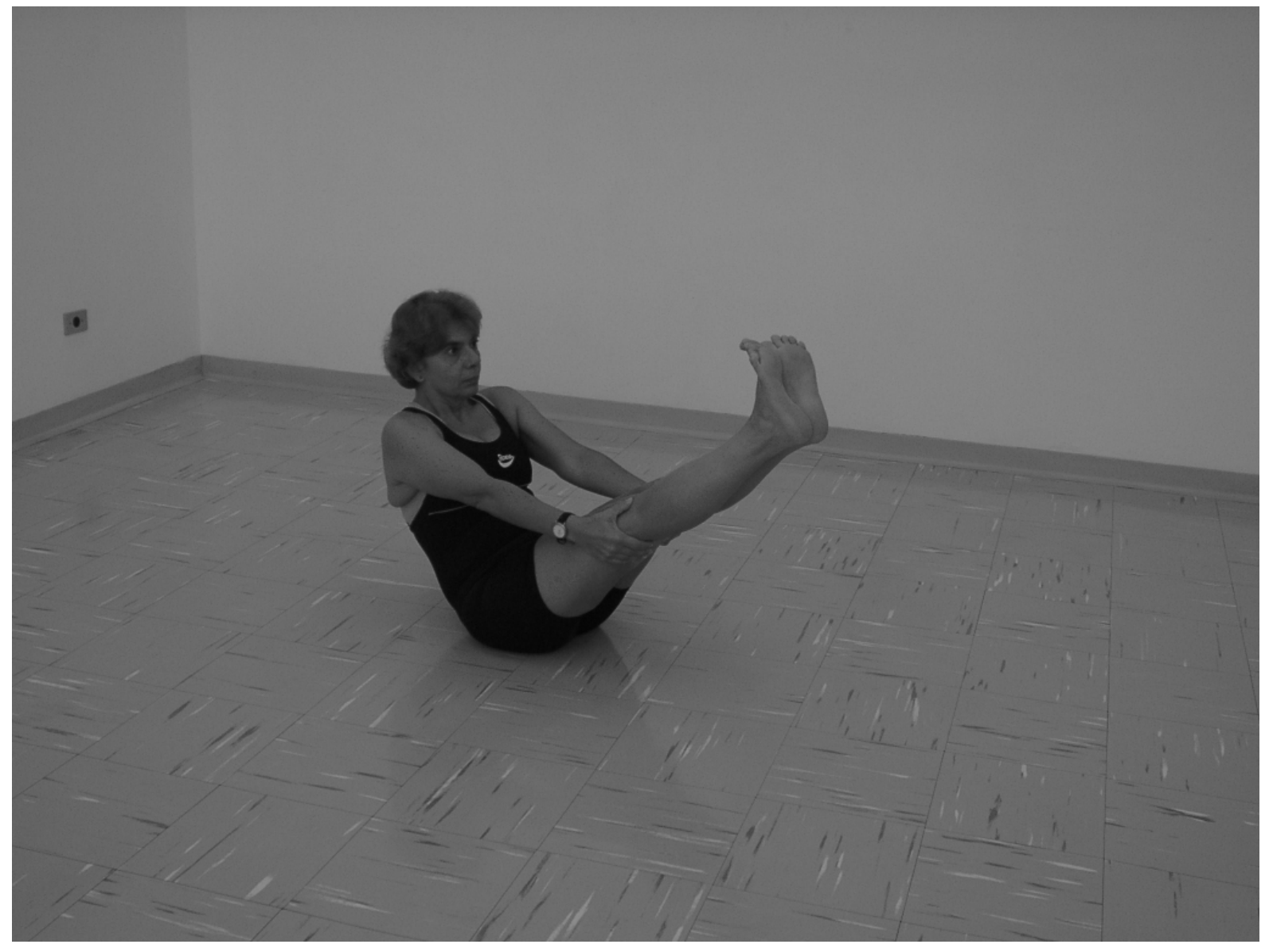




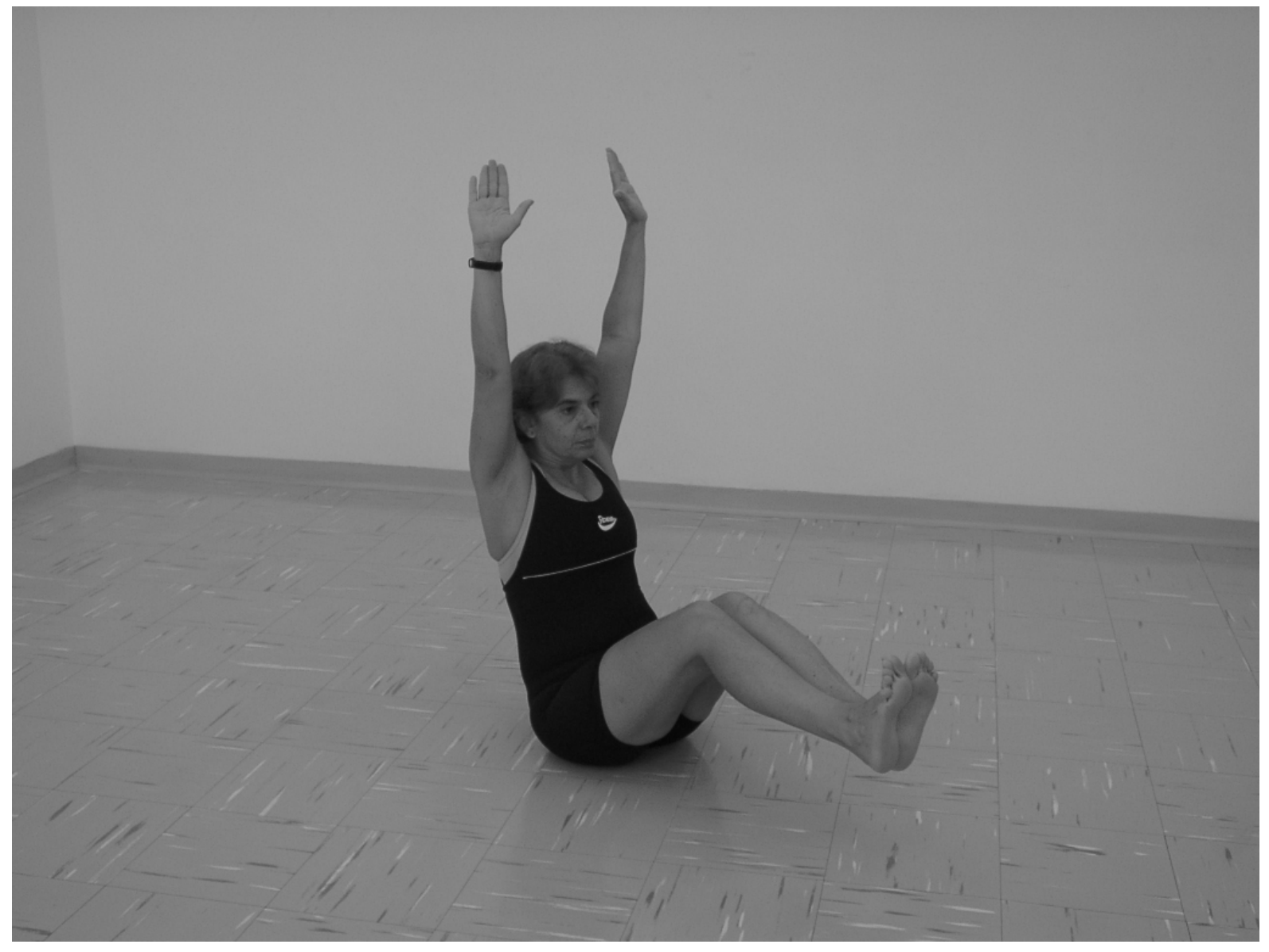




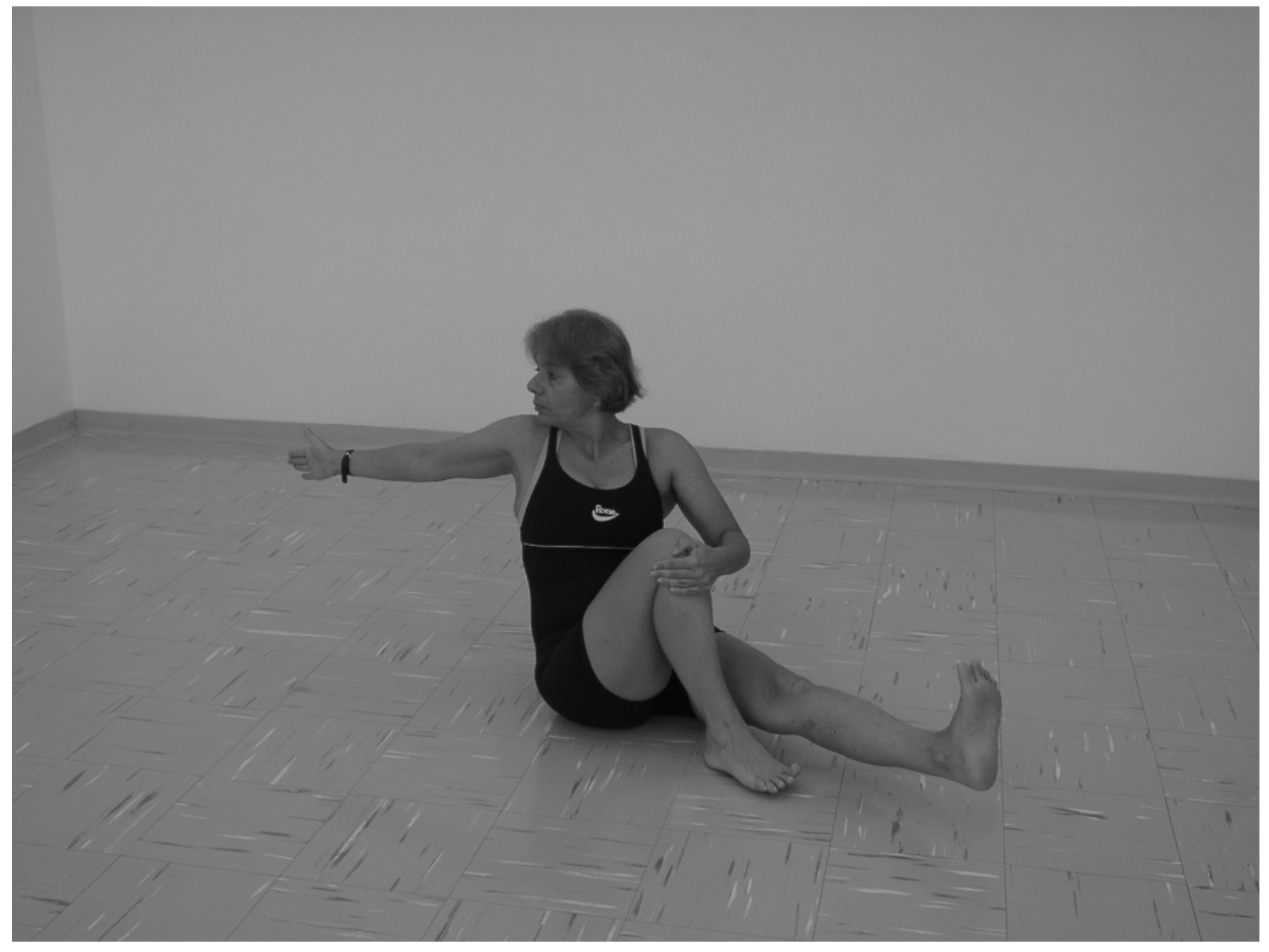




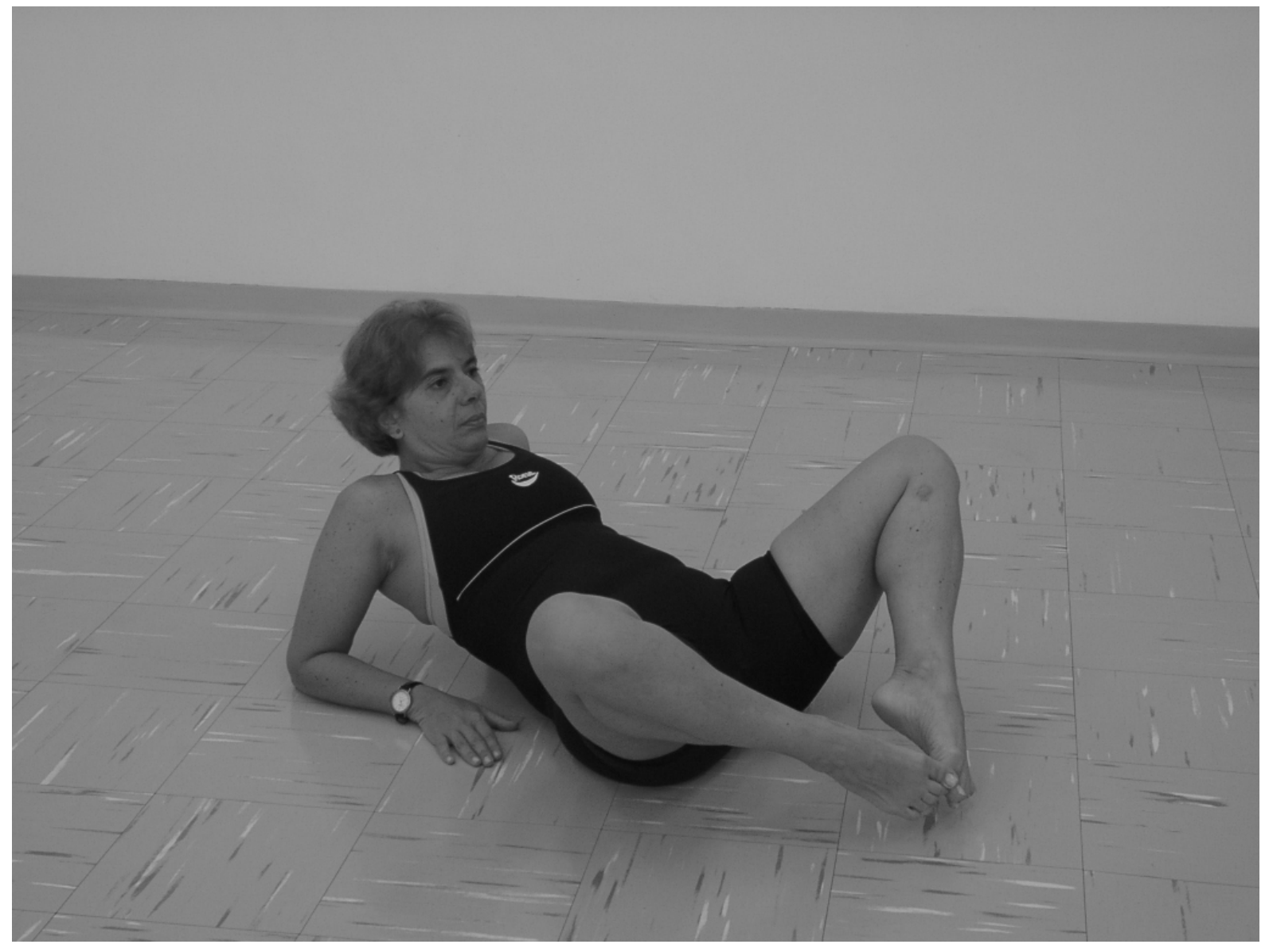




\section{NONA SEMANA}




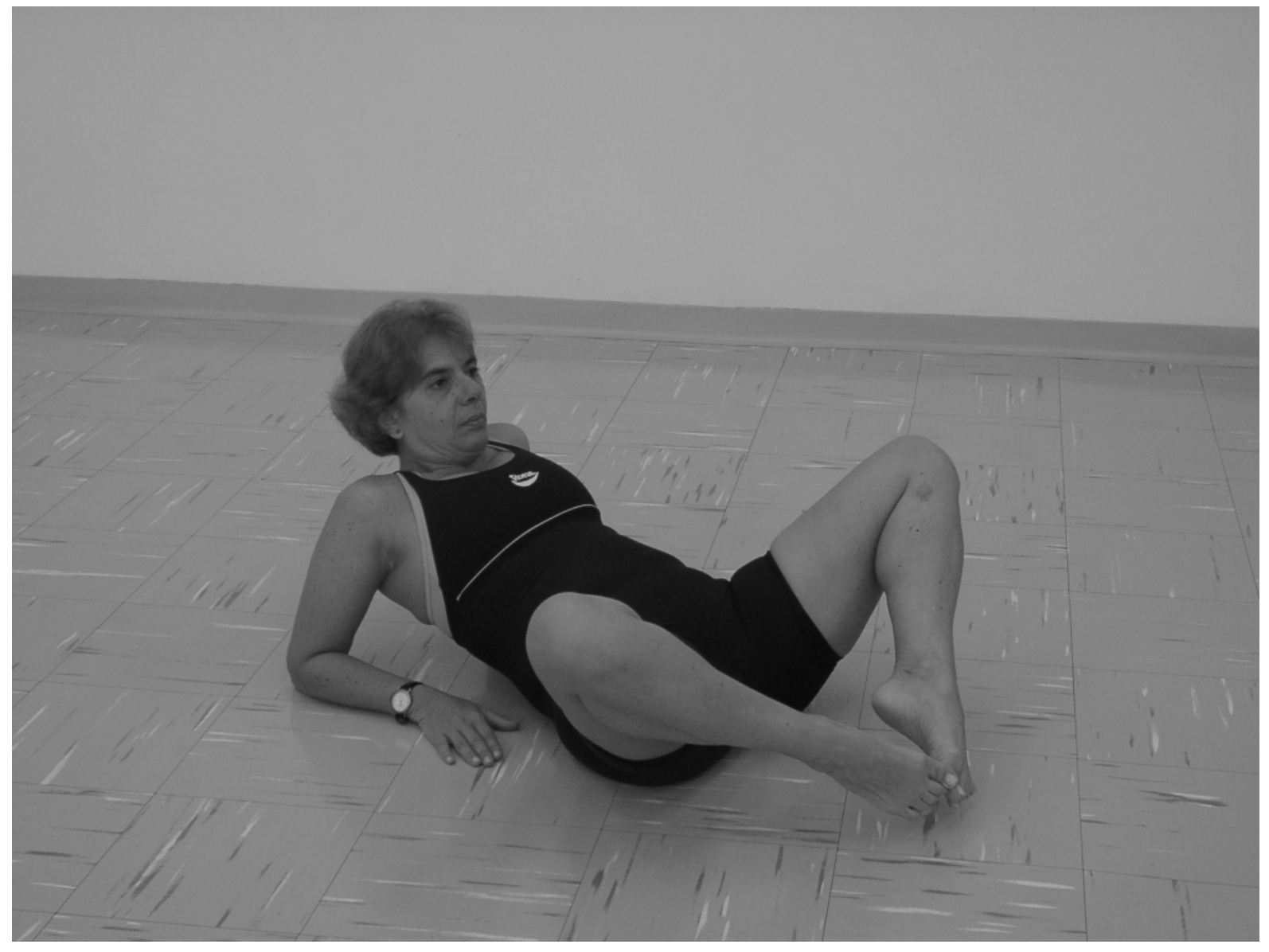




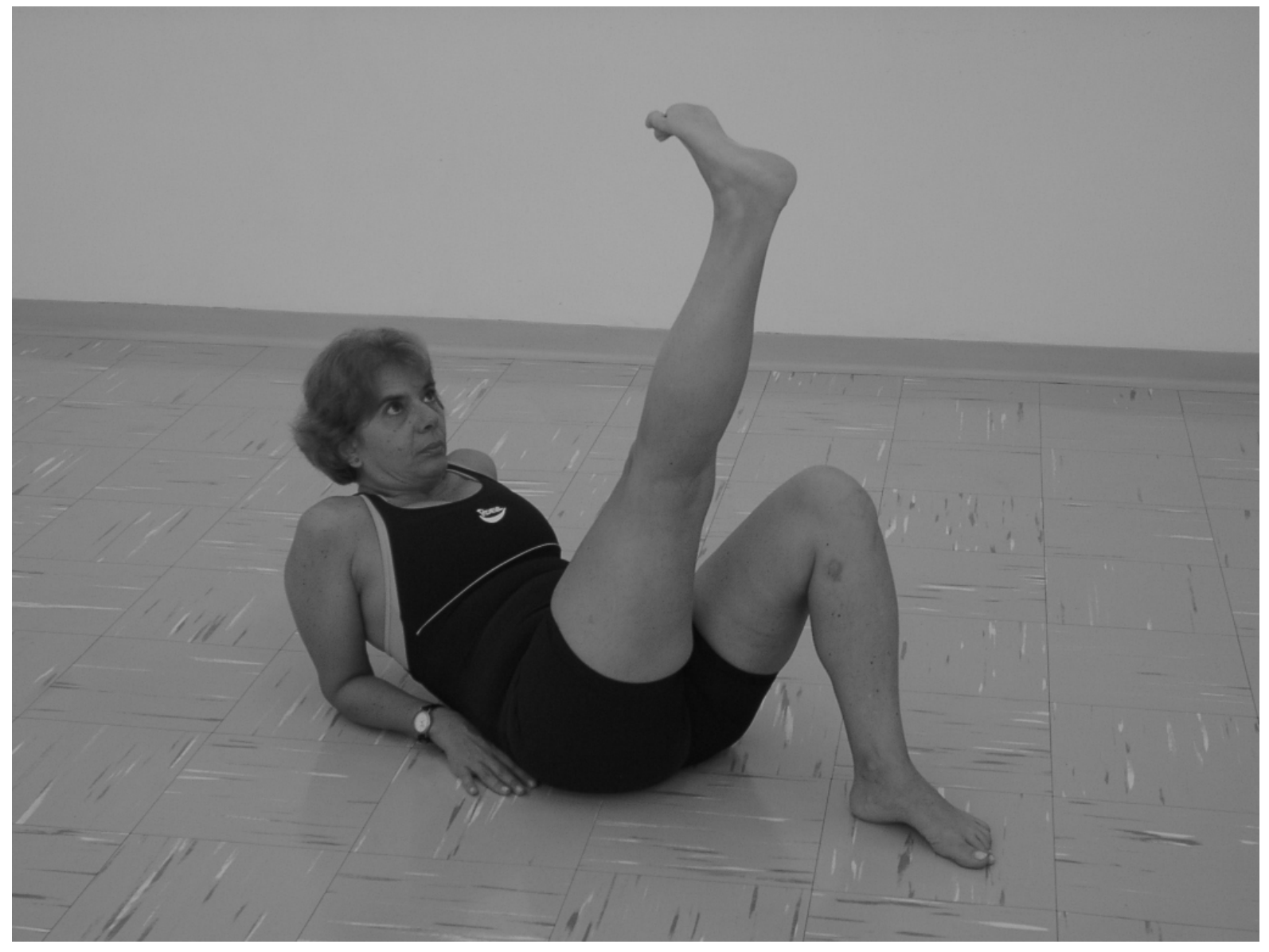




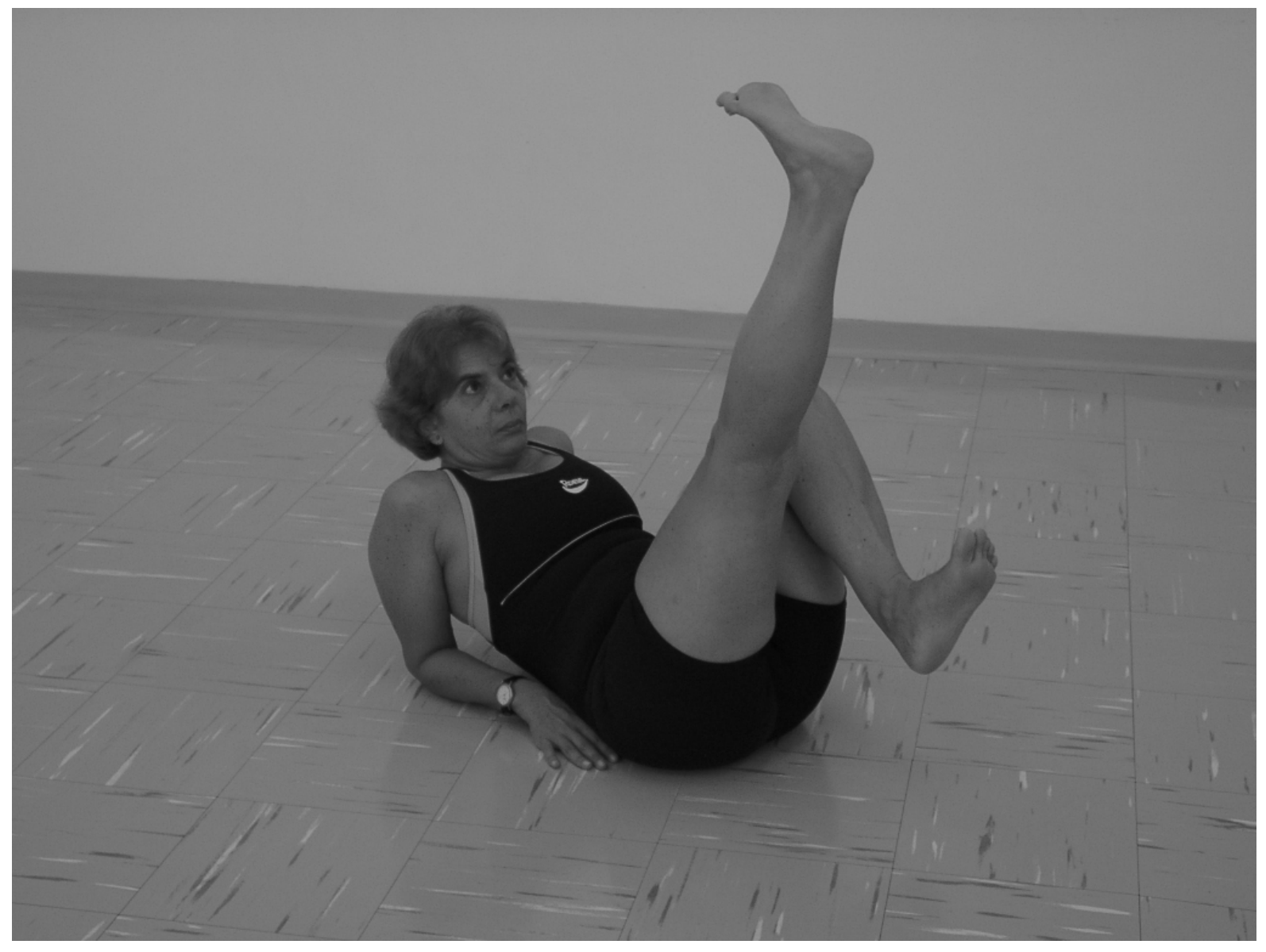




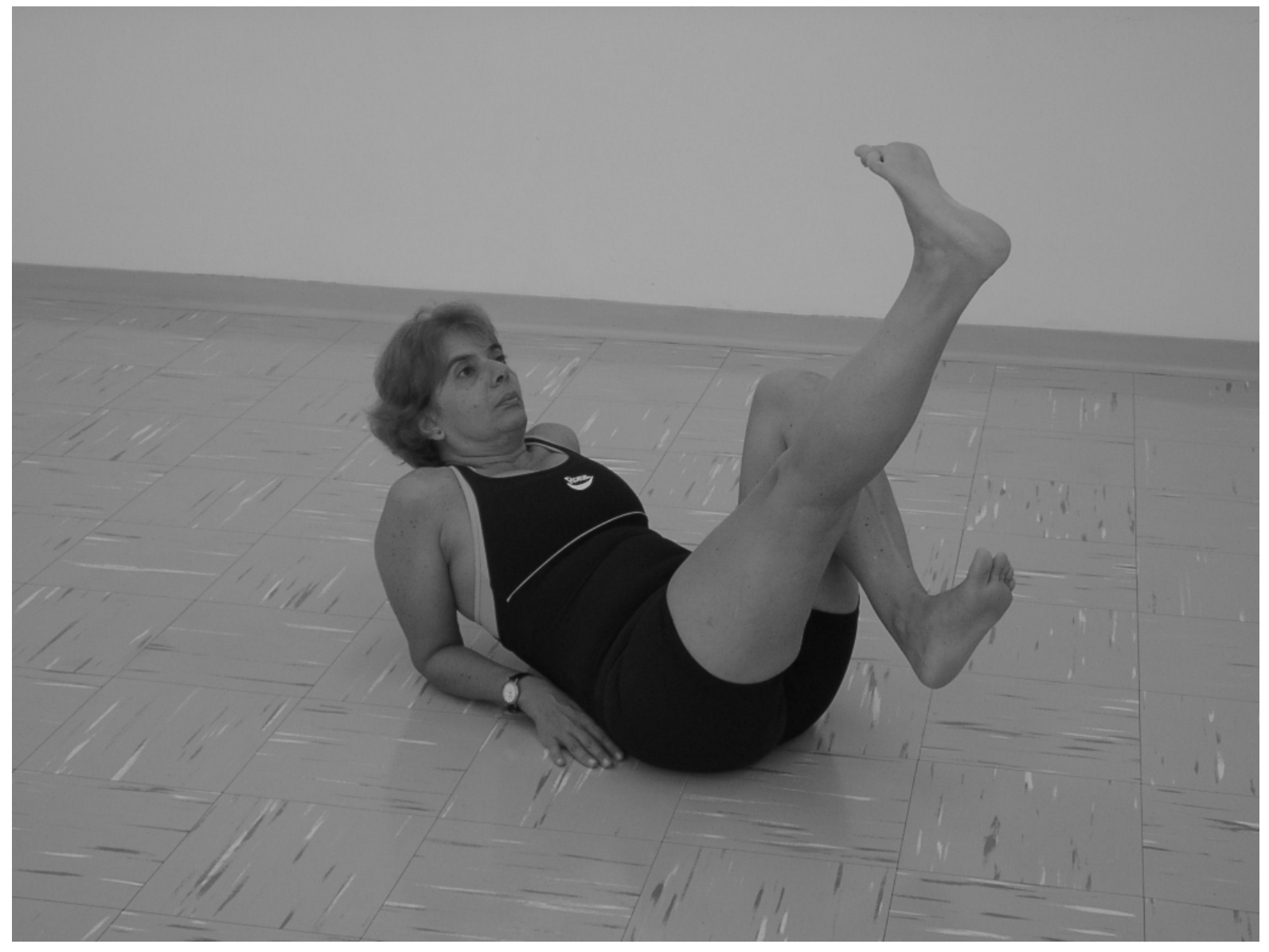




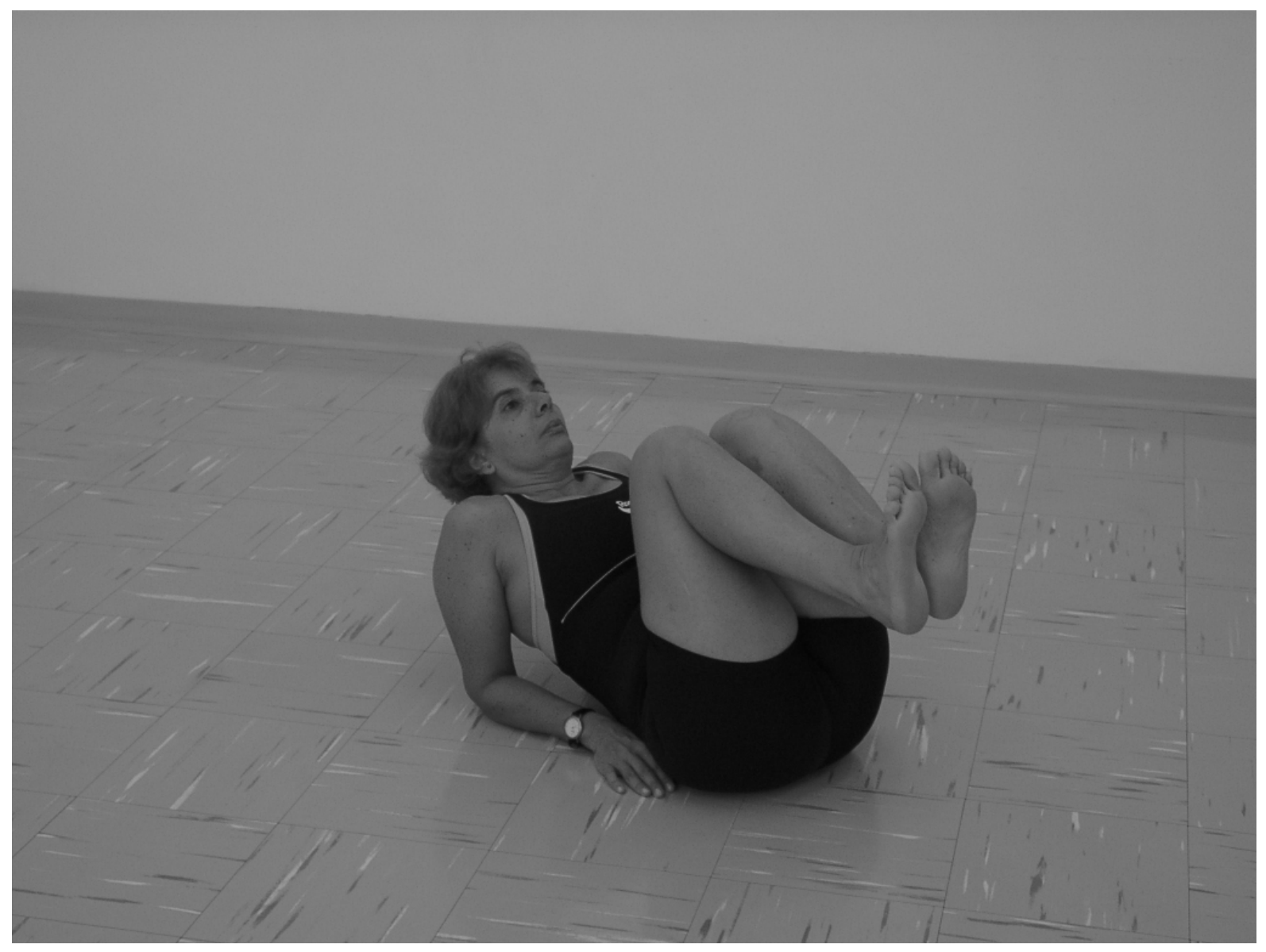




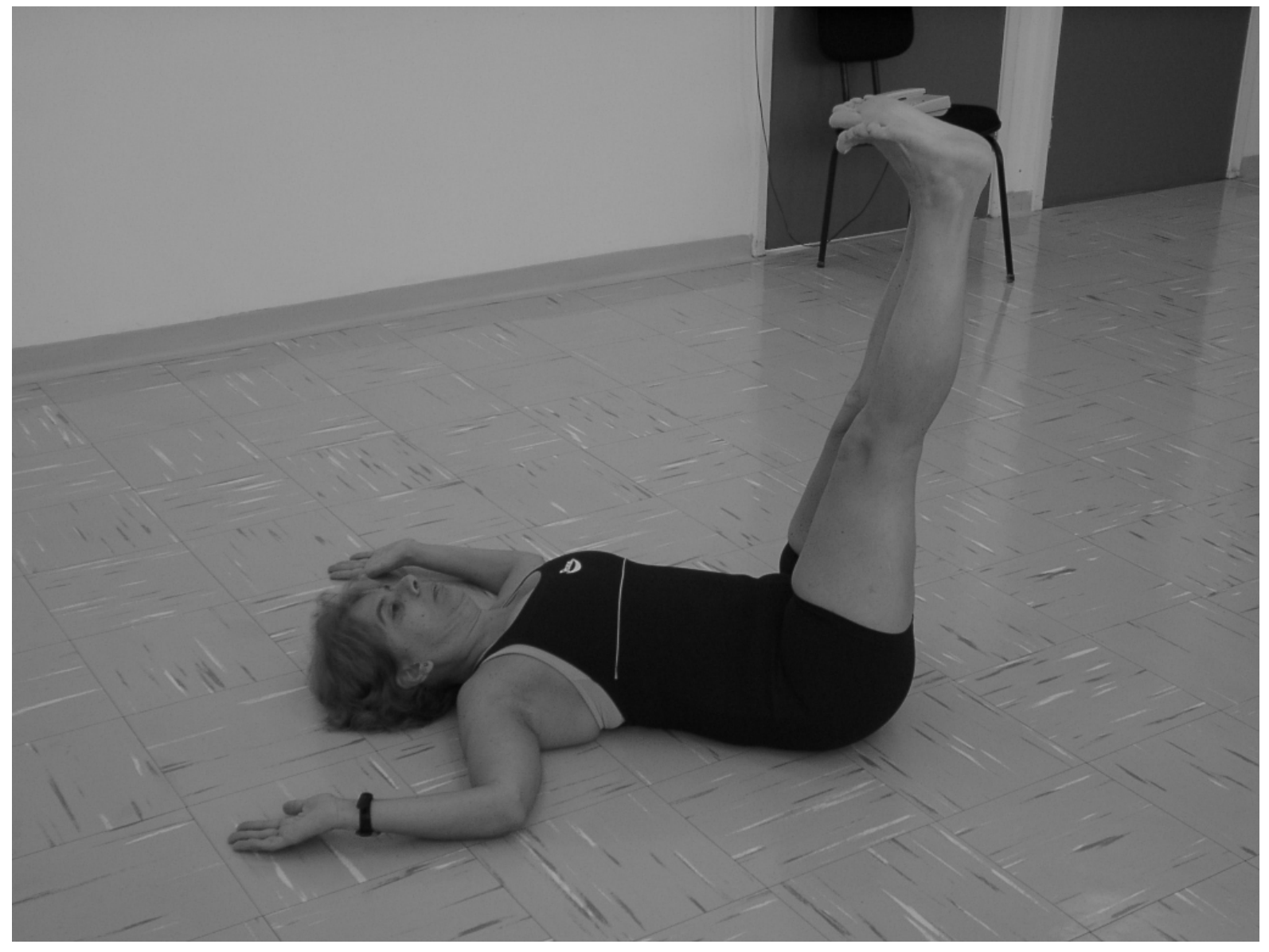




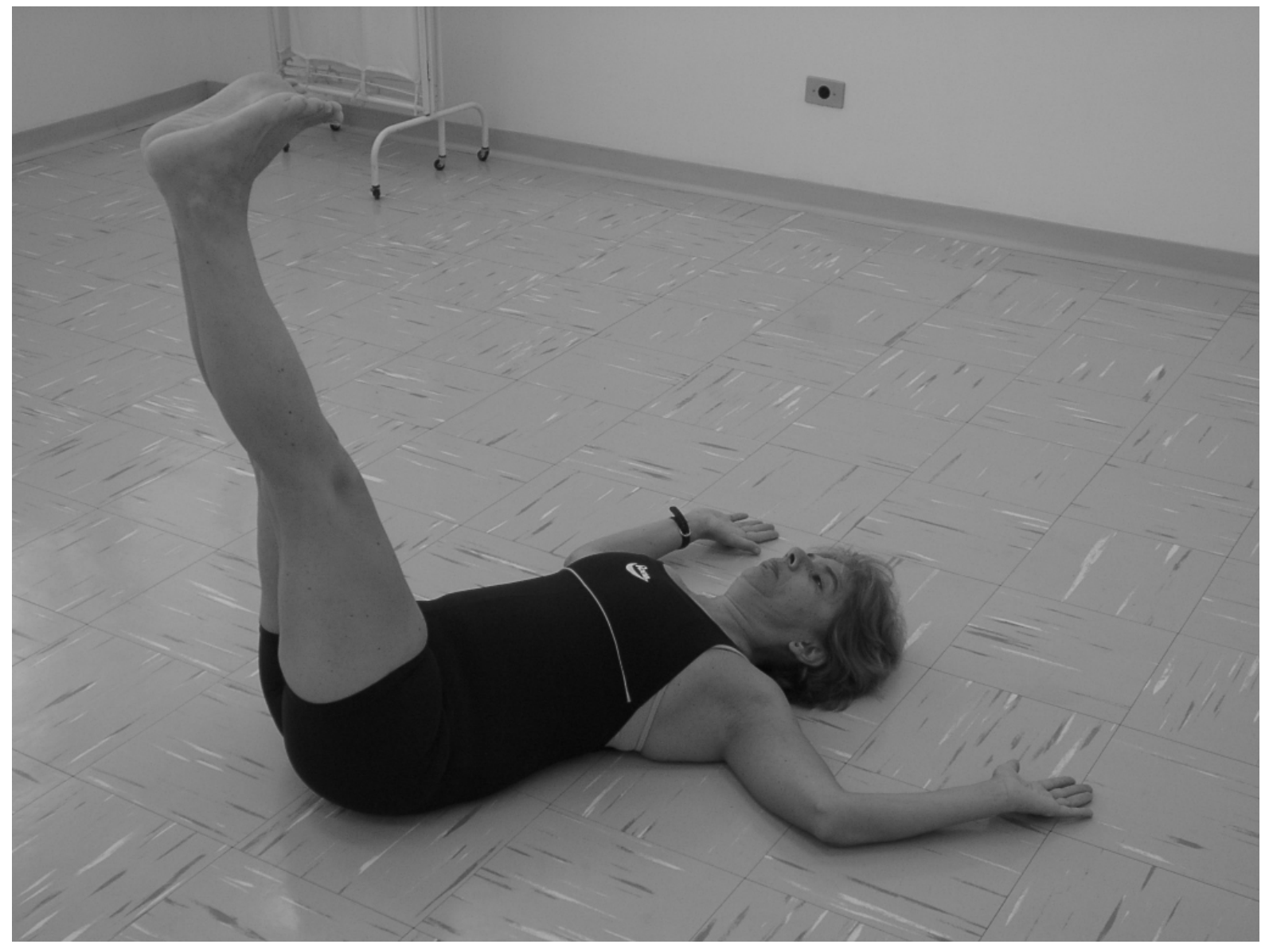




$$
\&
$$






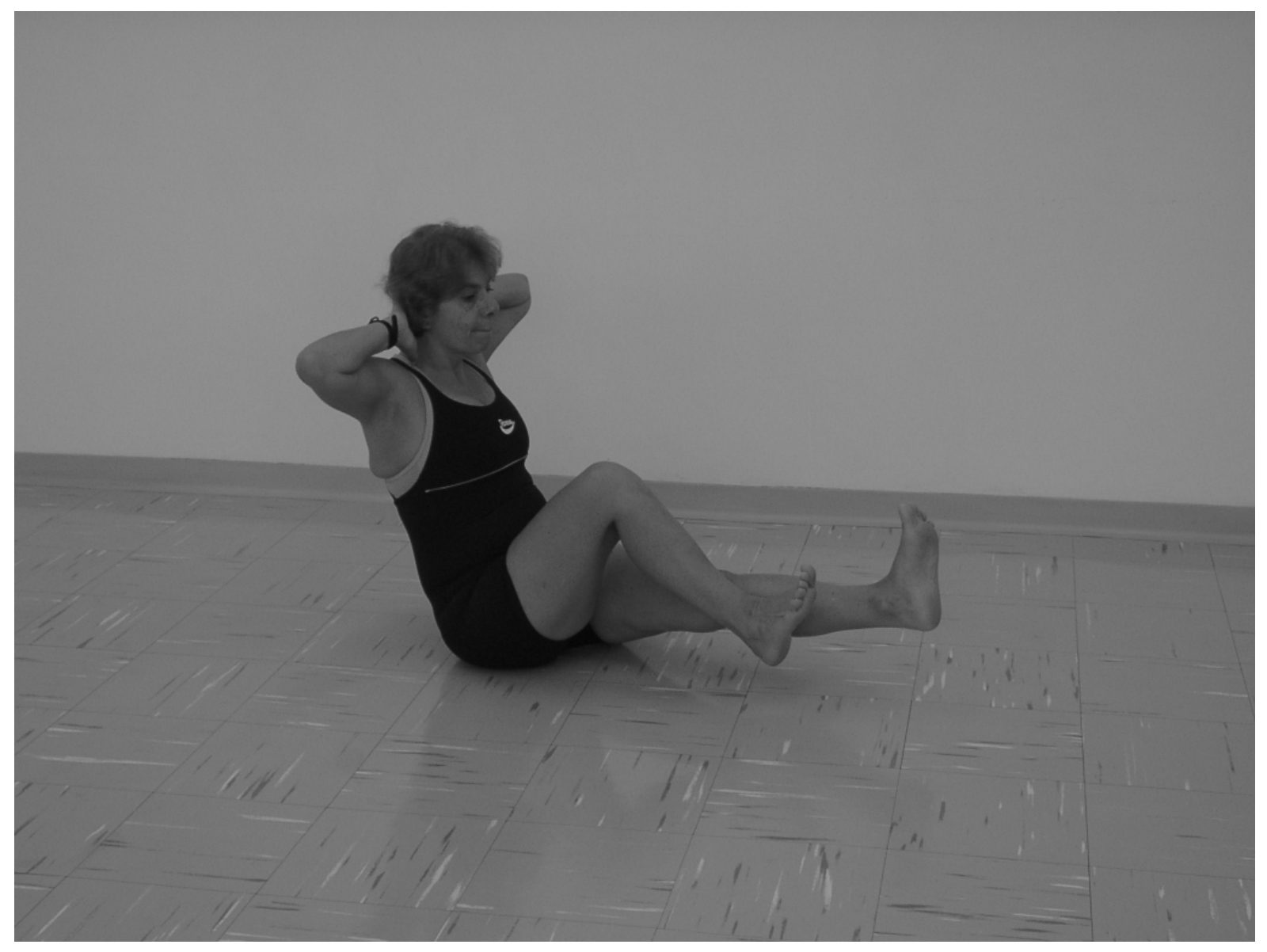




$$
t
$$




$$
k
$$




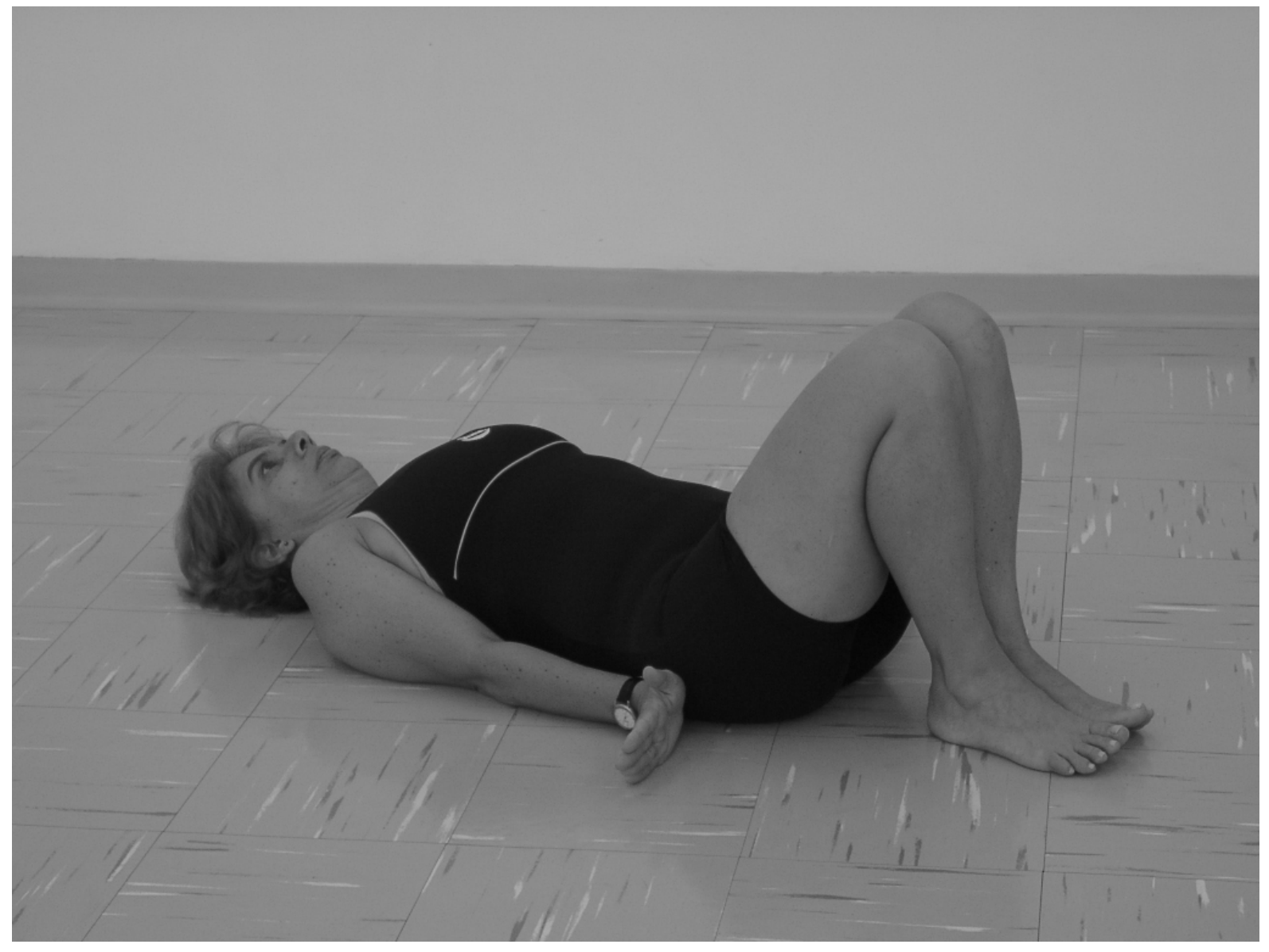




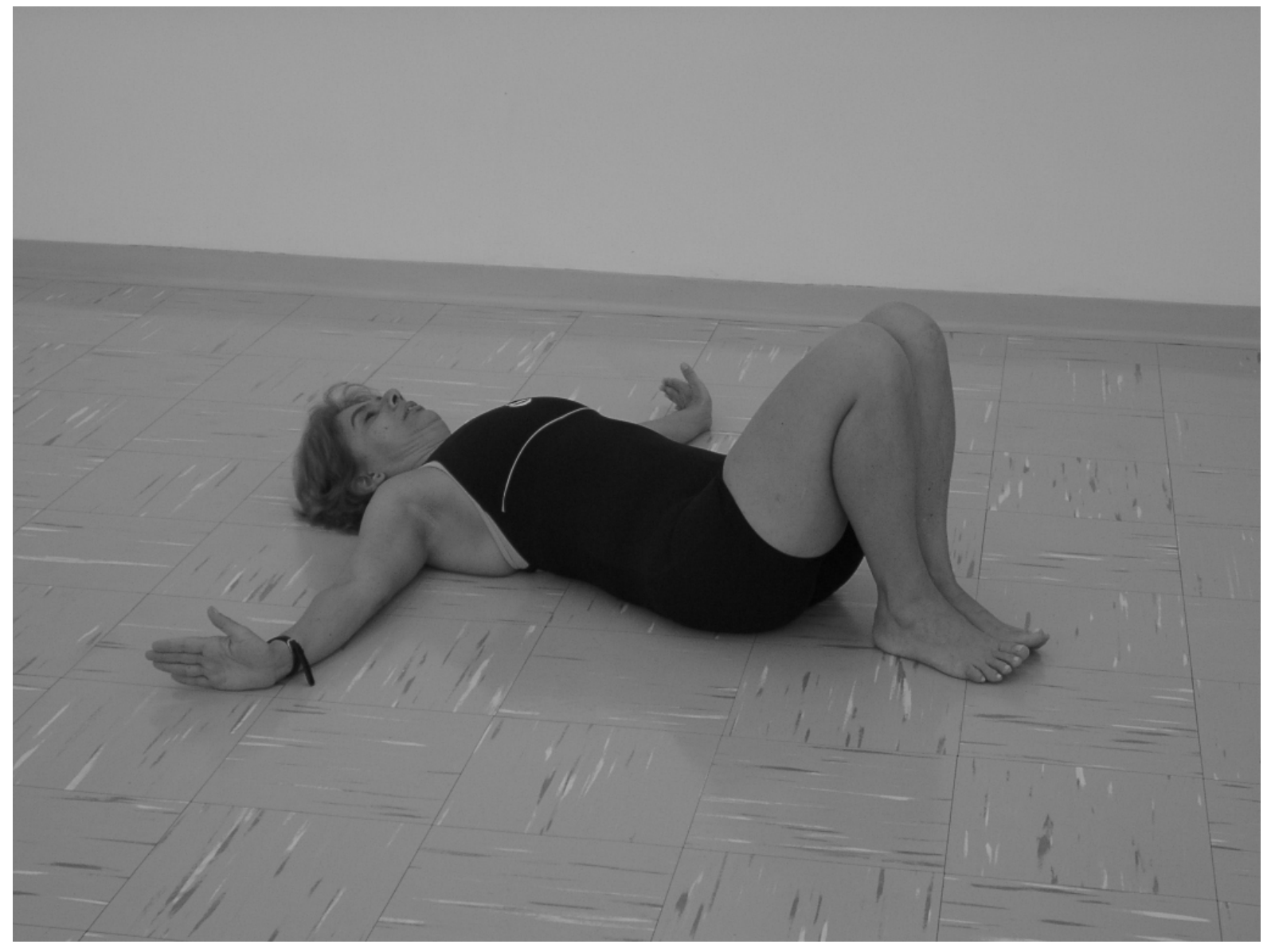




\section{DÉCIMA SEMANA}




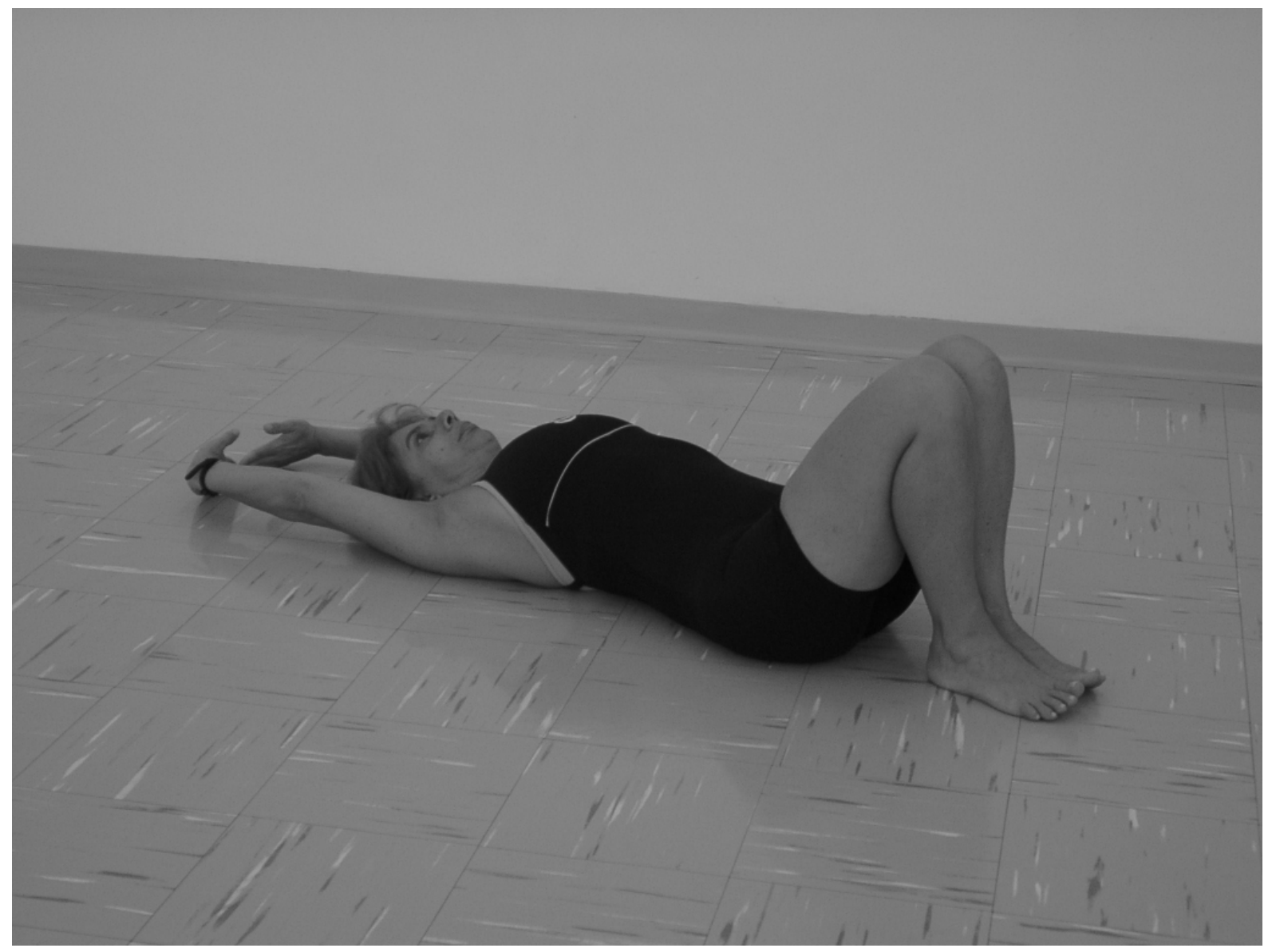




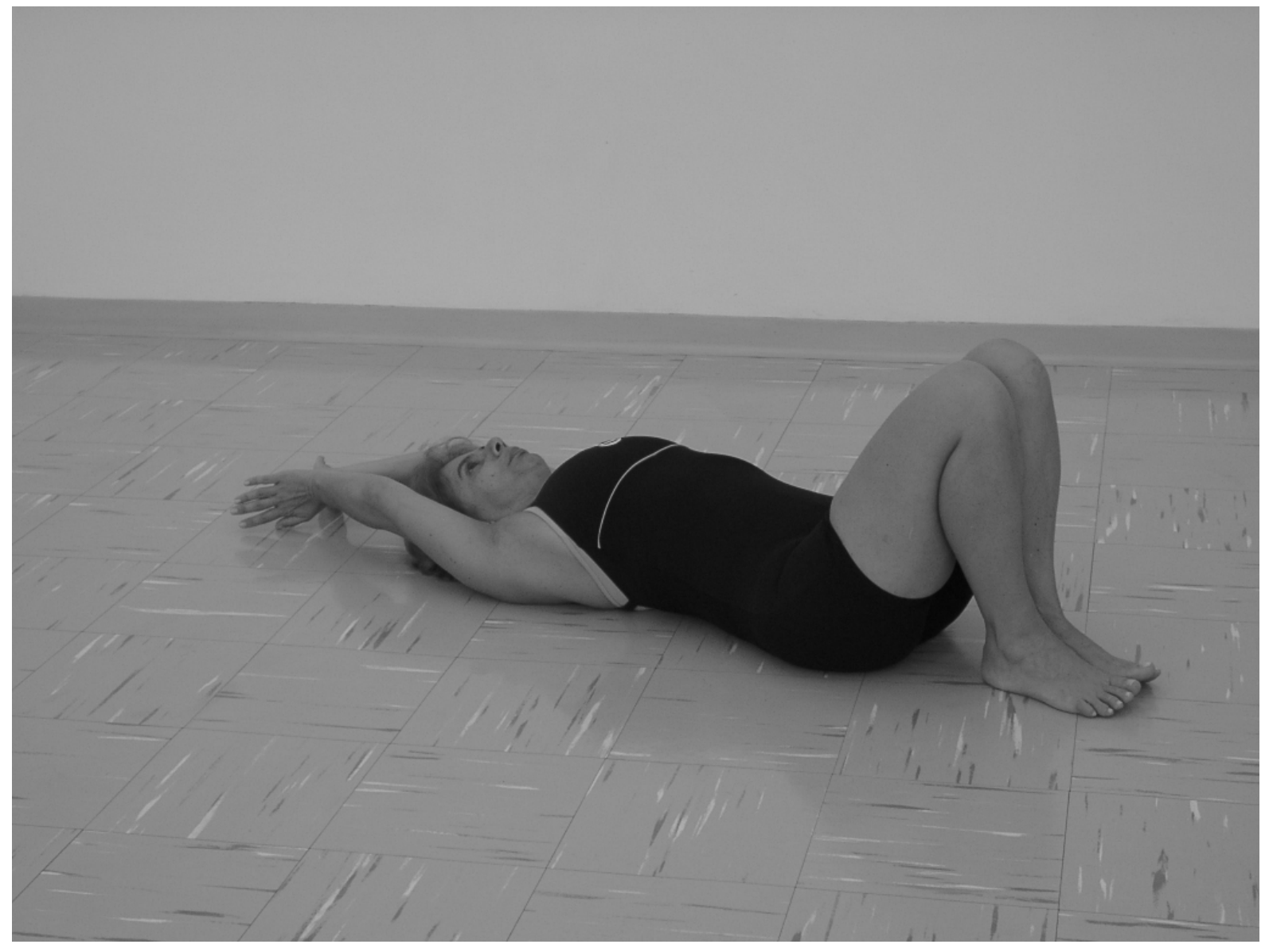




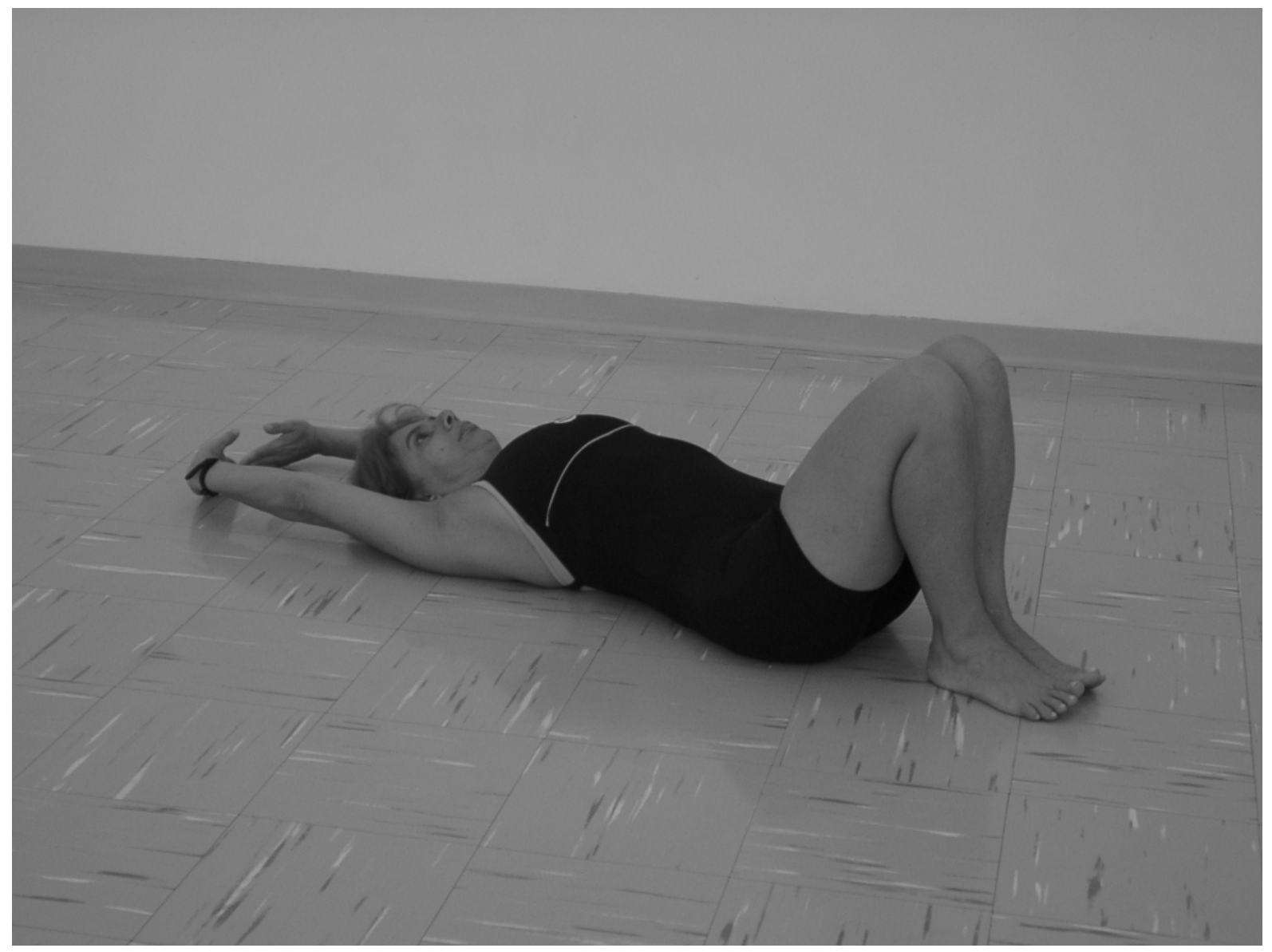




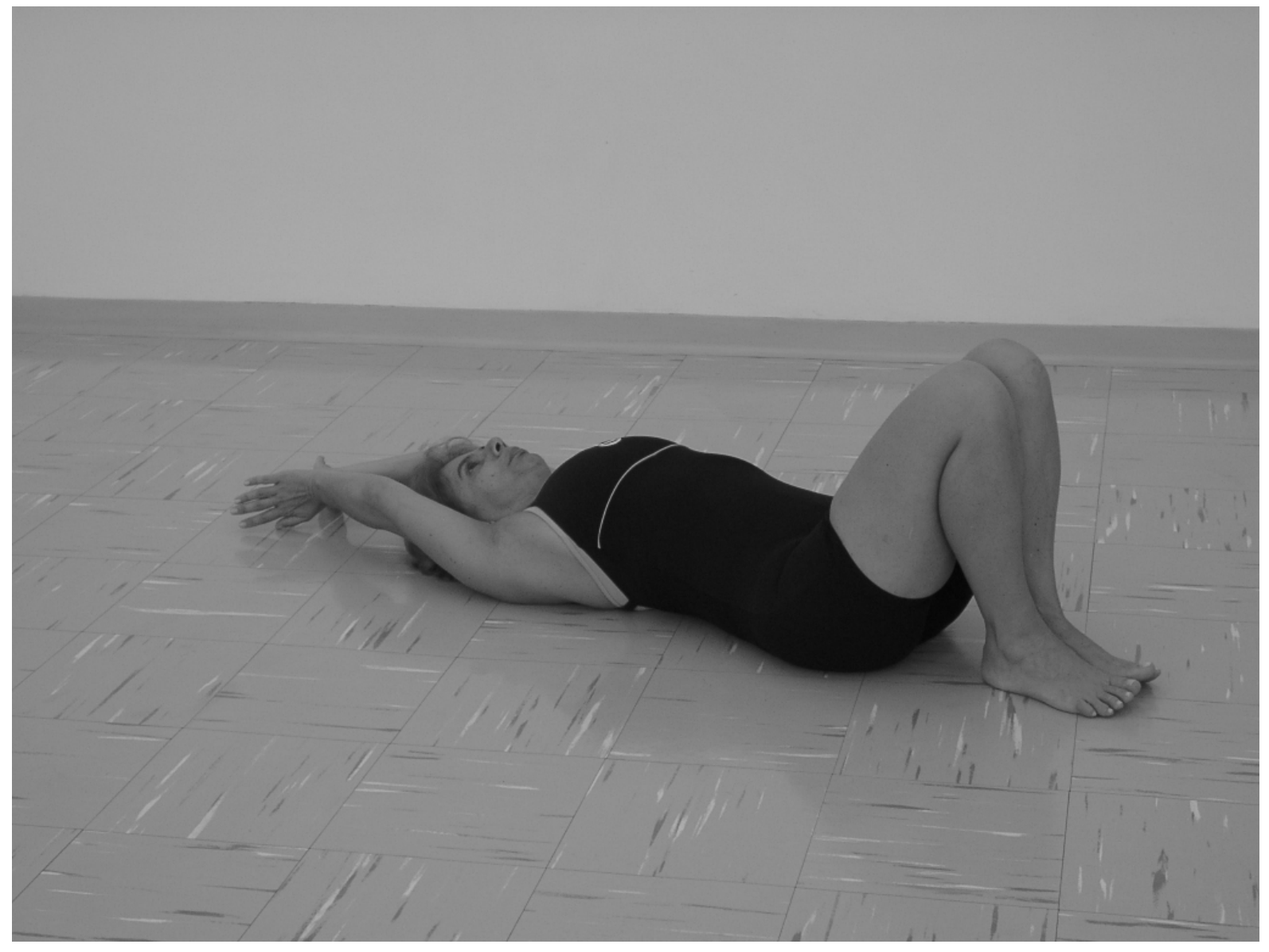




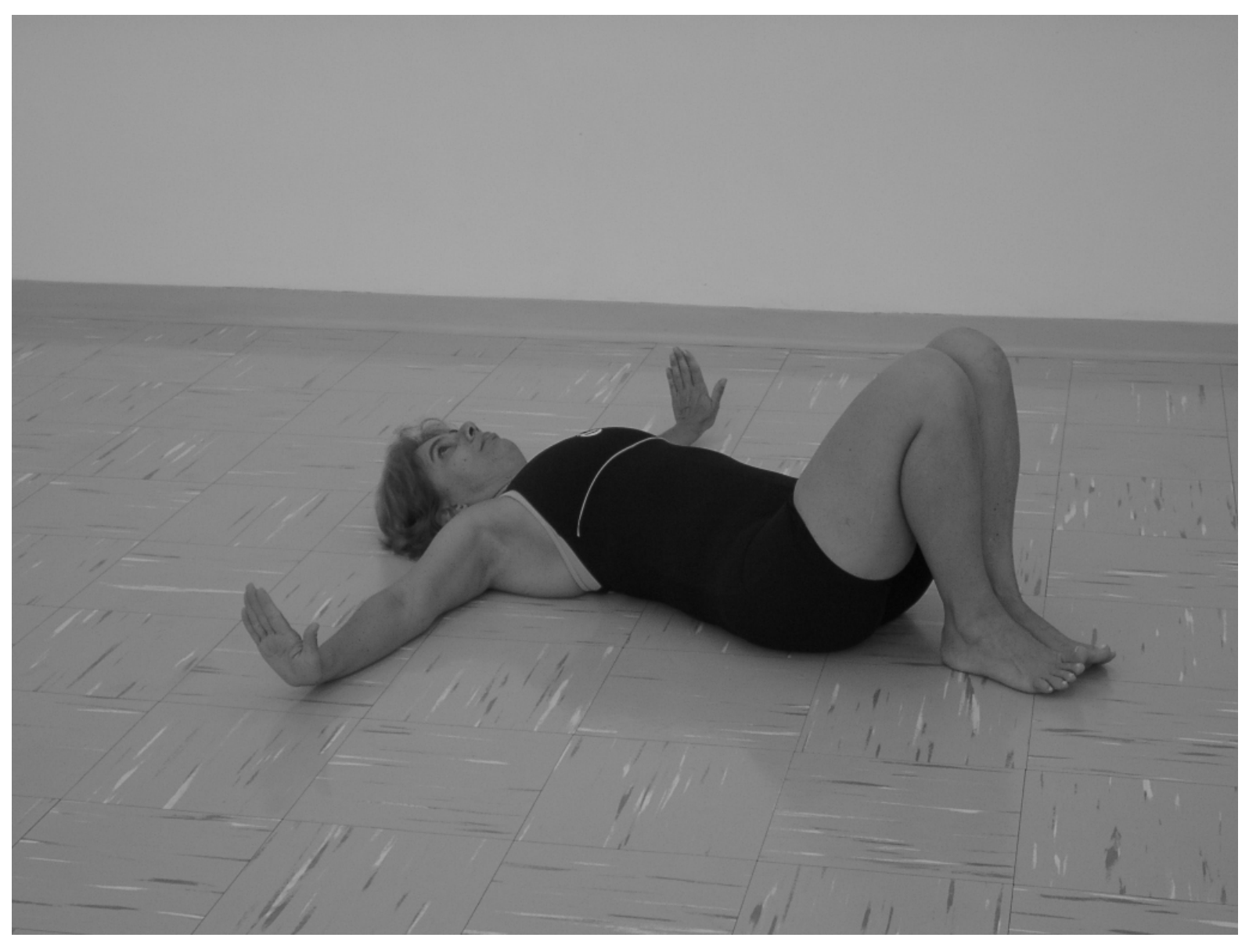




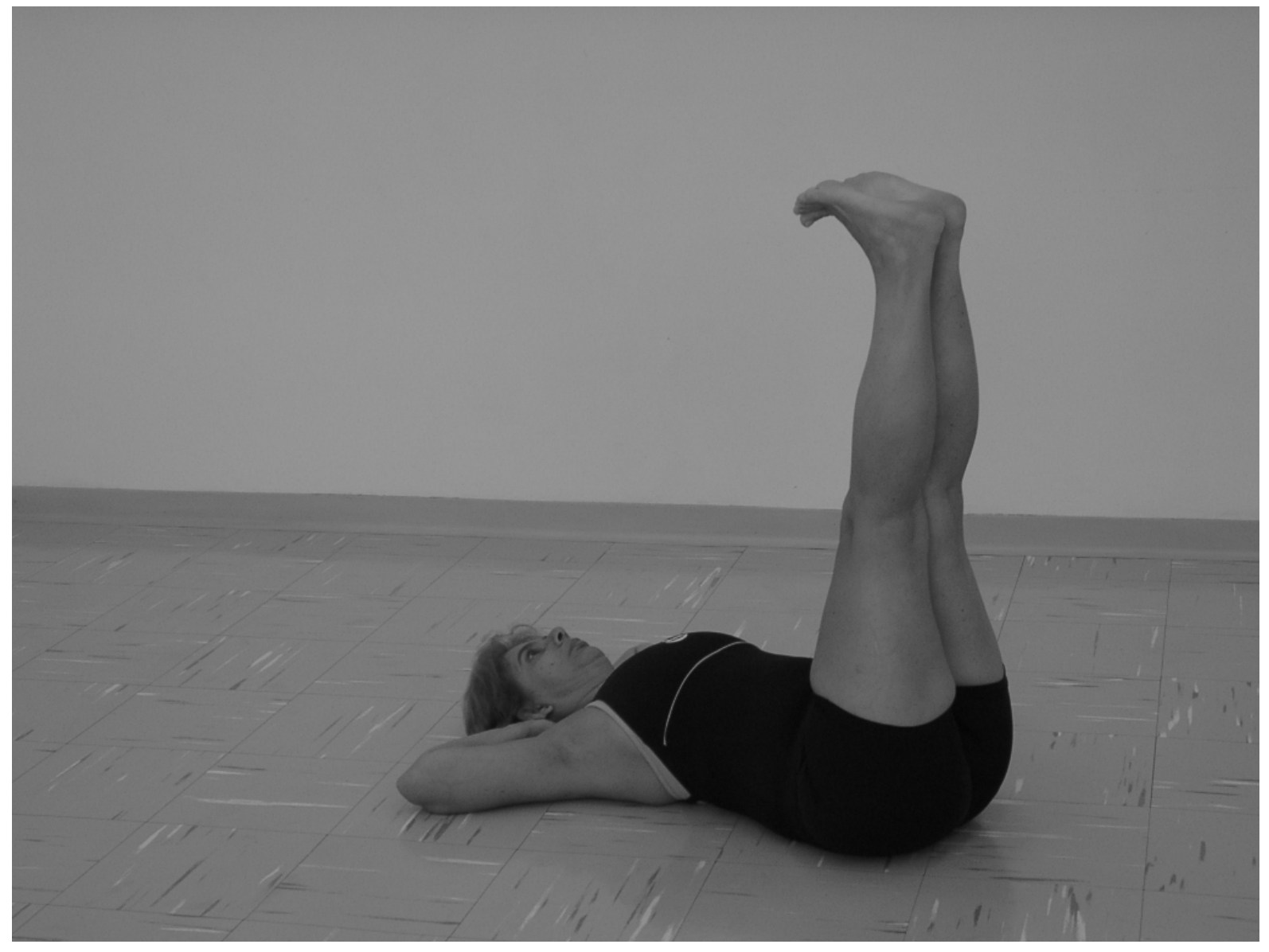




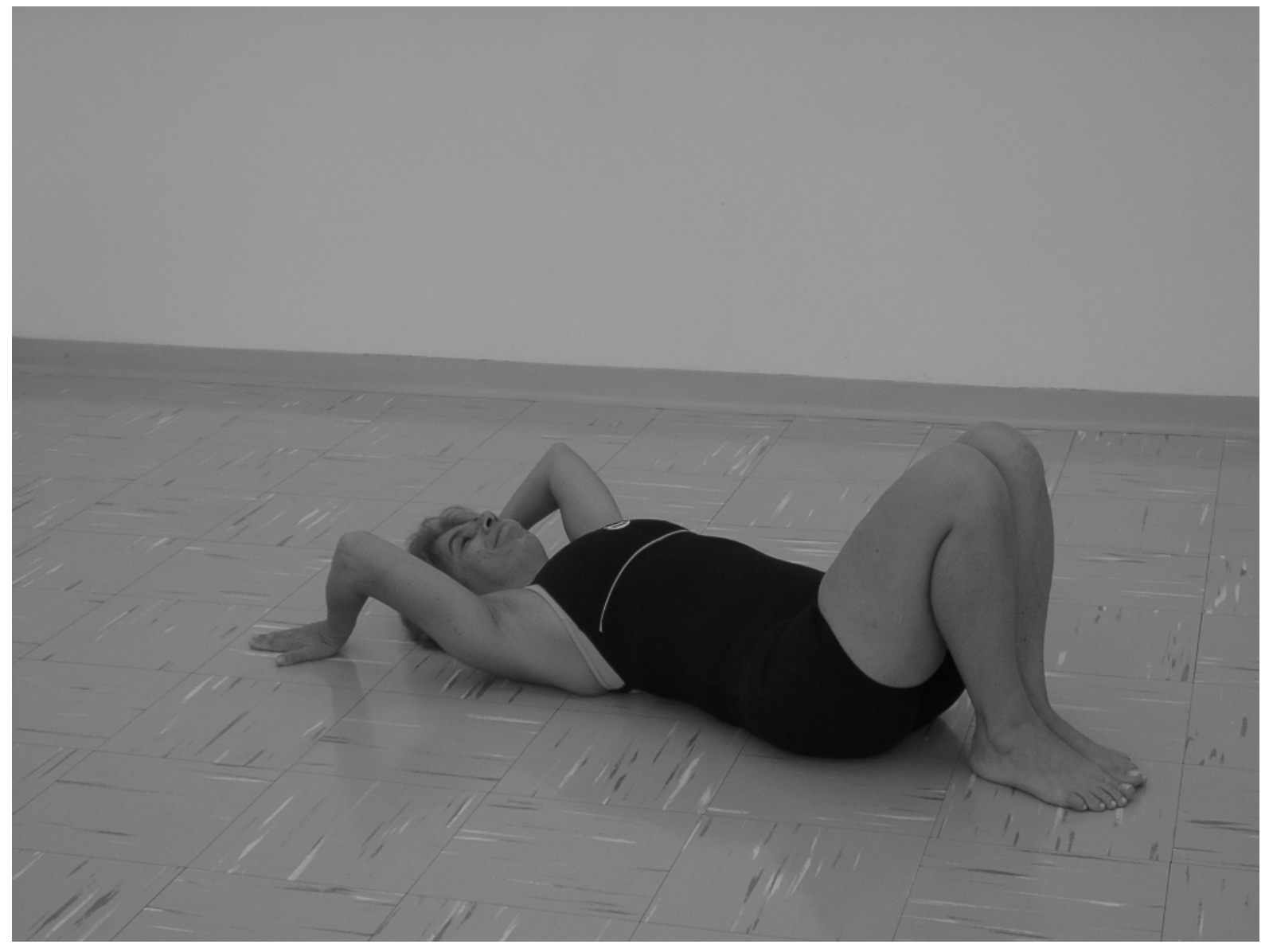




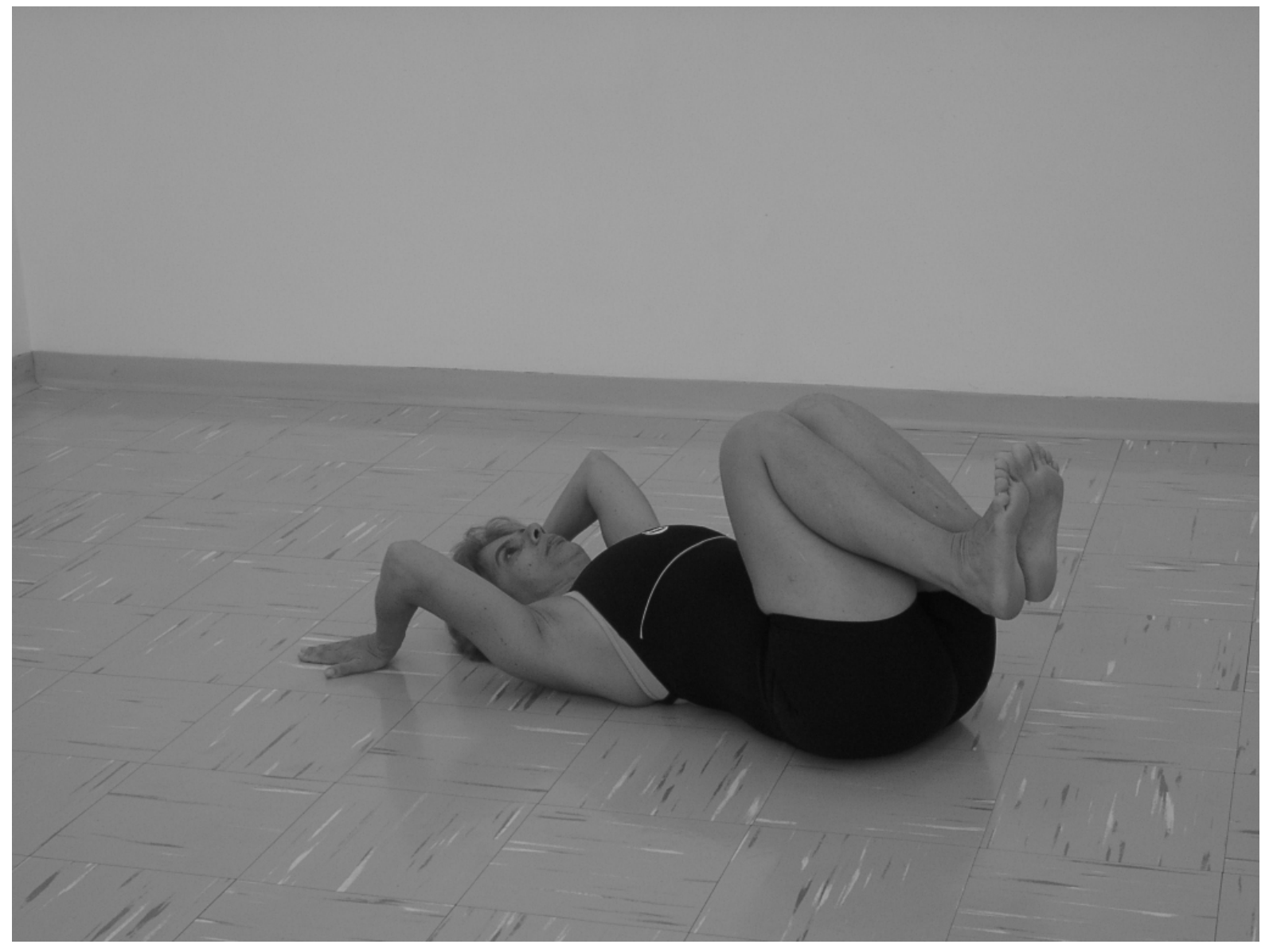




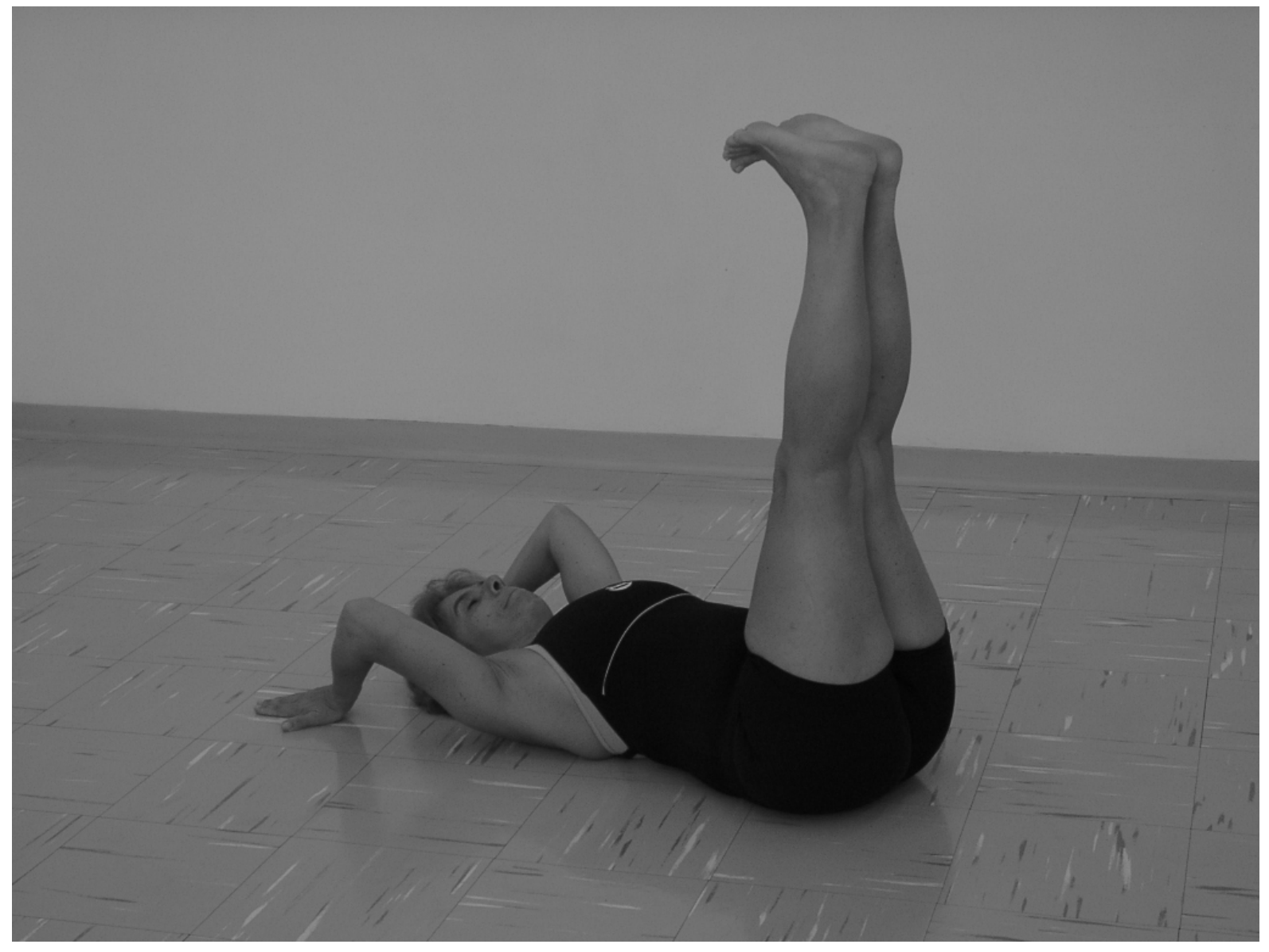




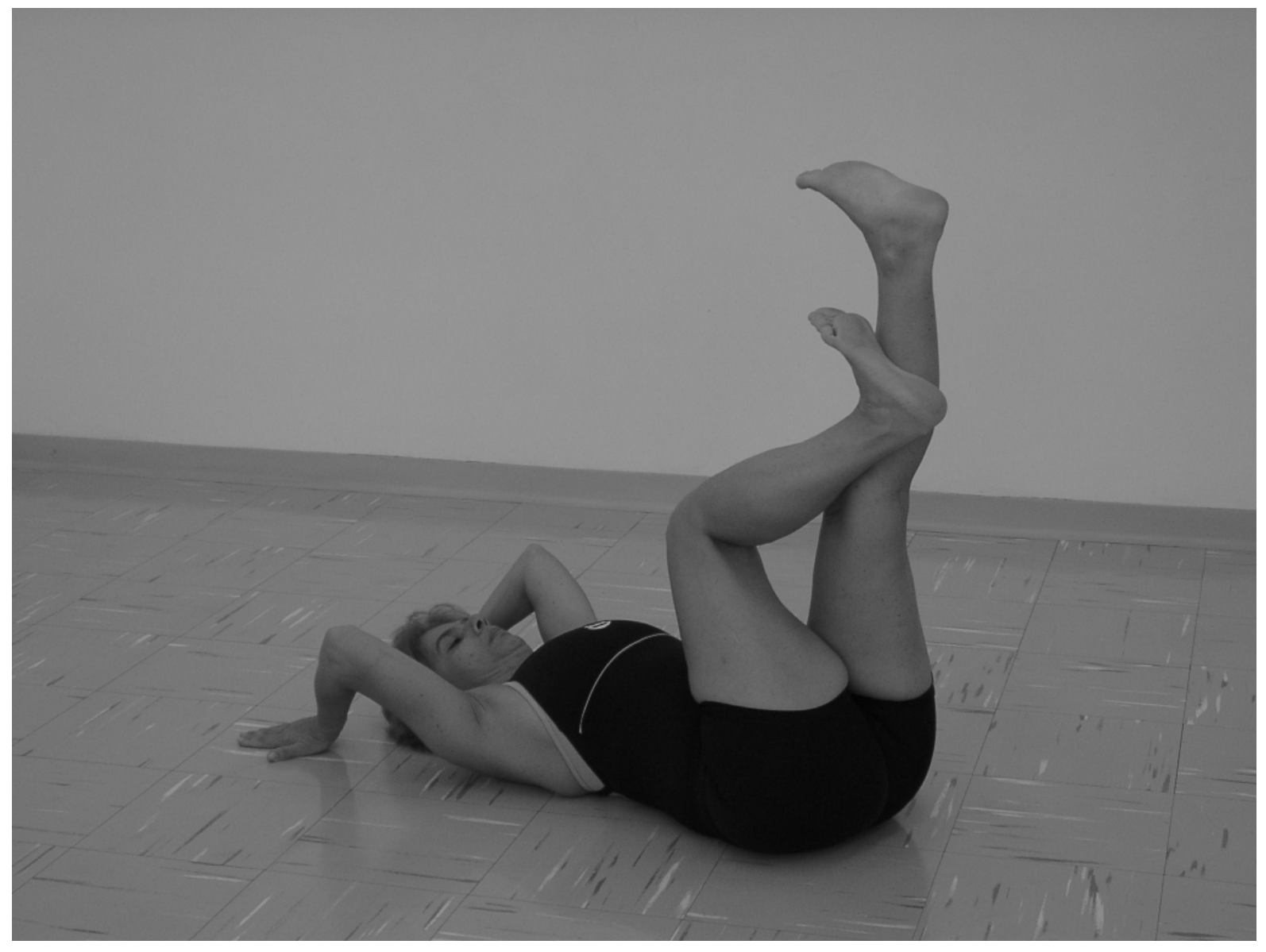





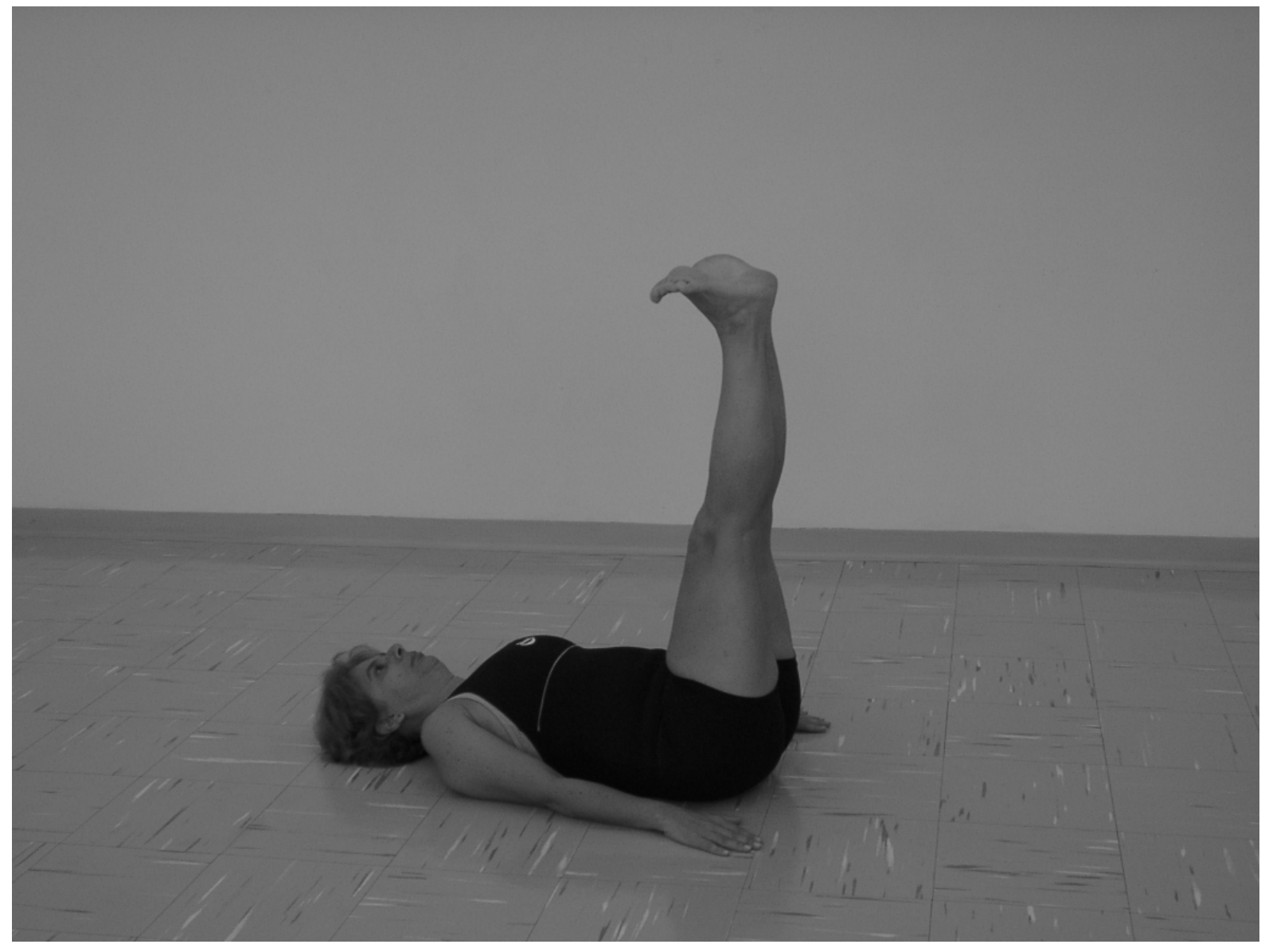




$$
\sigma
$$




$$
\sigma
$$




\section{DÉCIMA PRIMEIRA SEMANA}




$$
d
$$




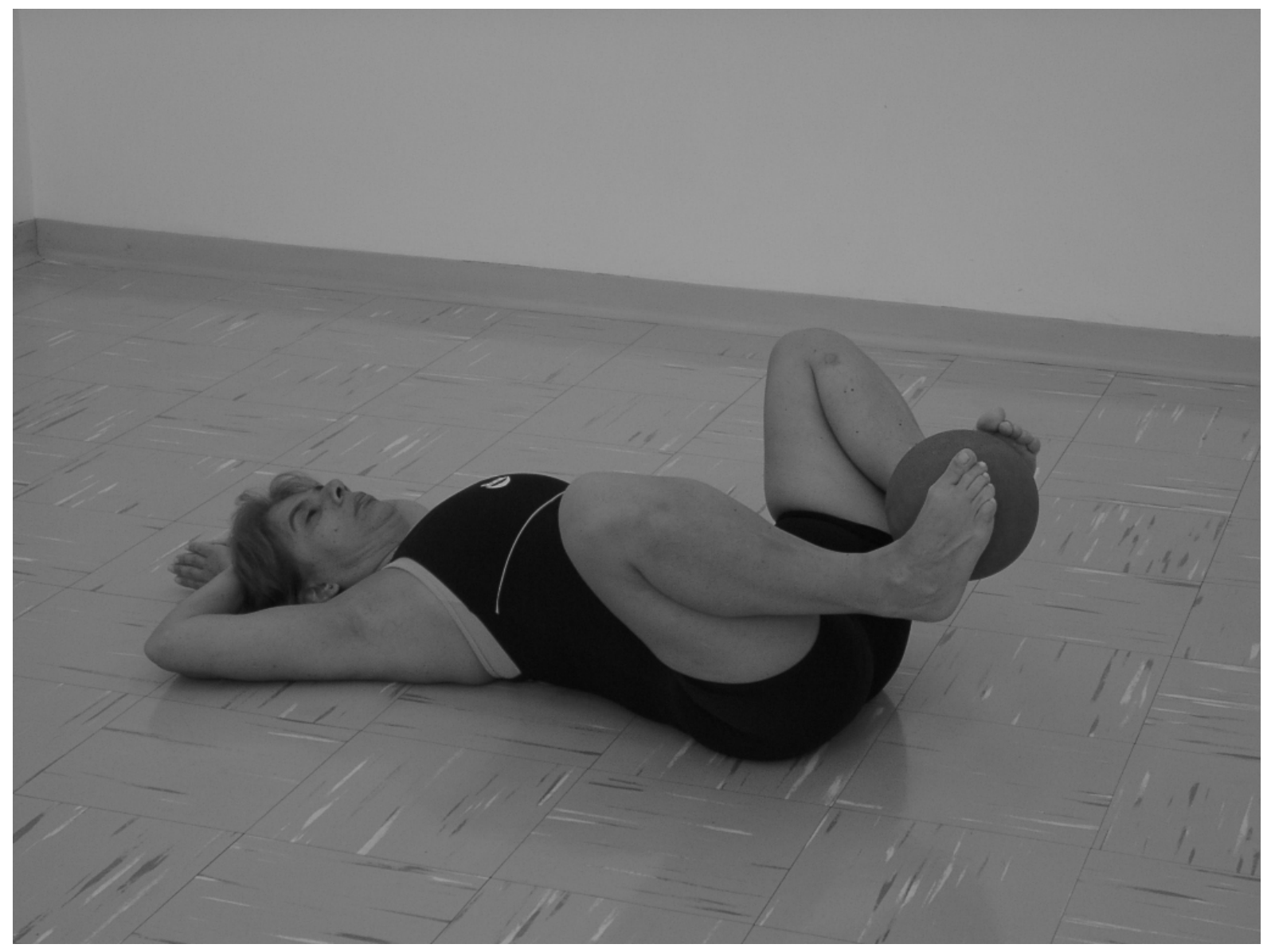





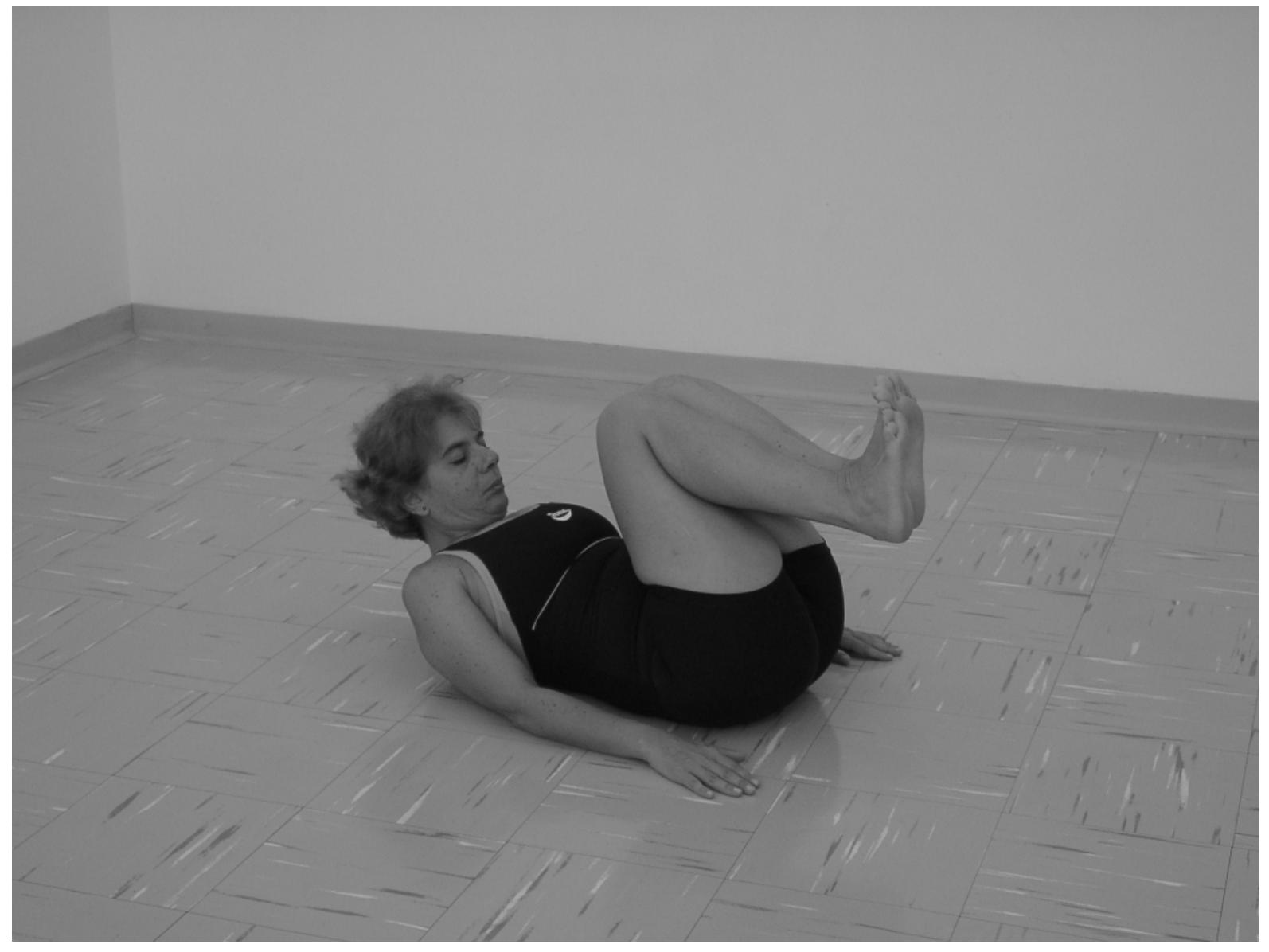




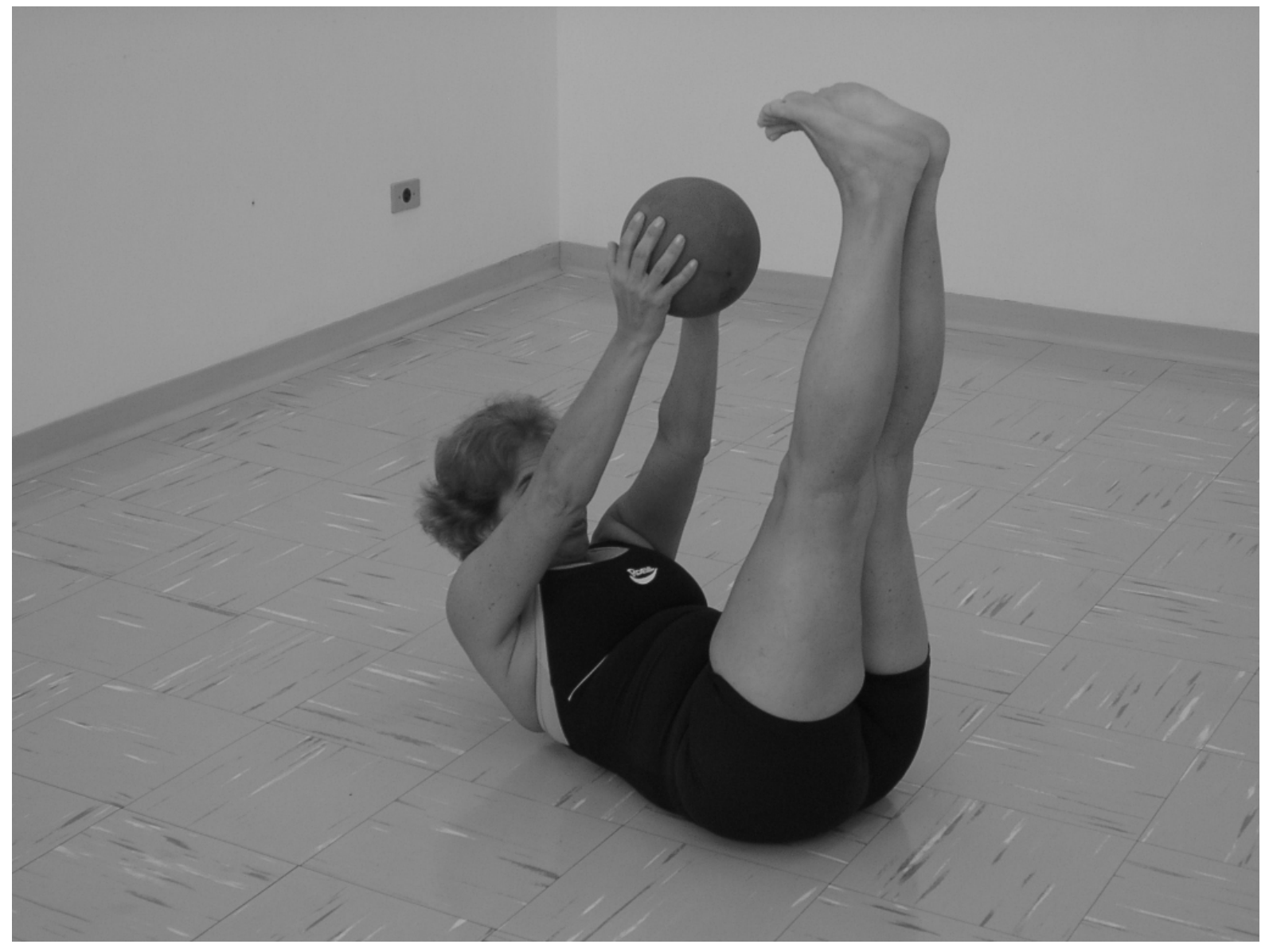




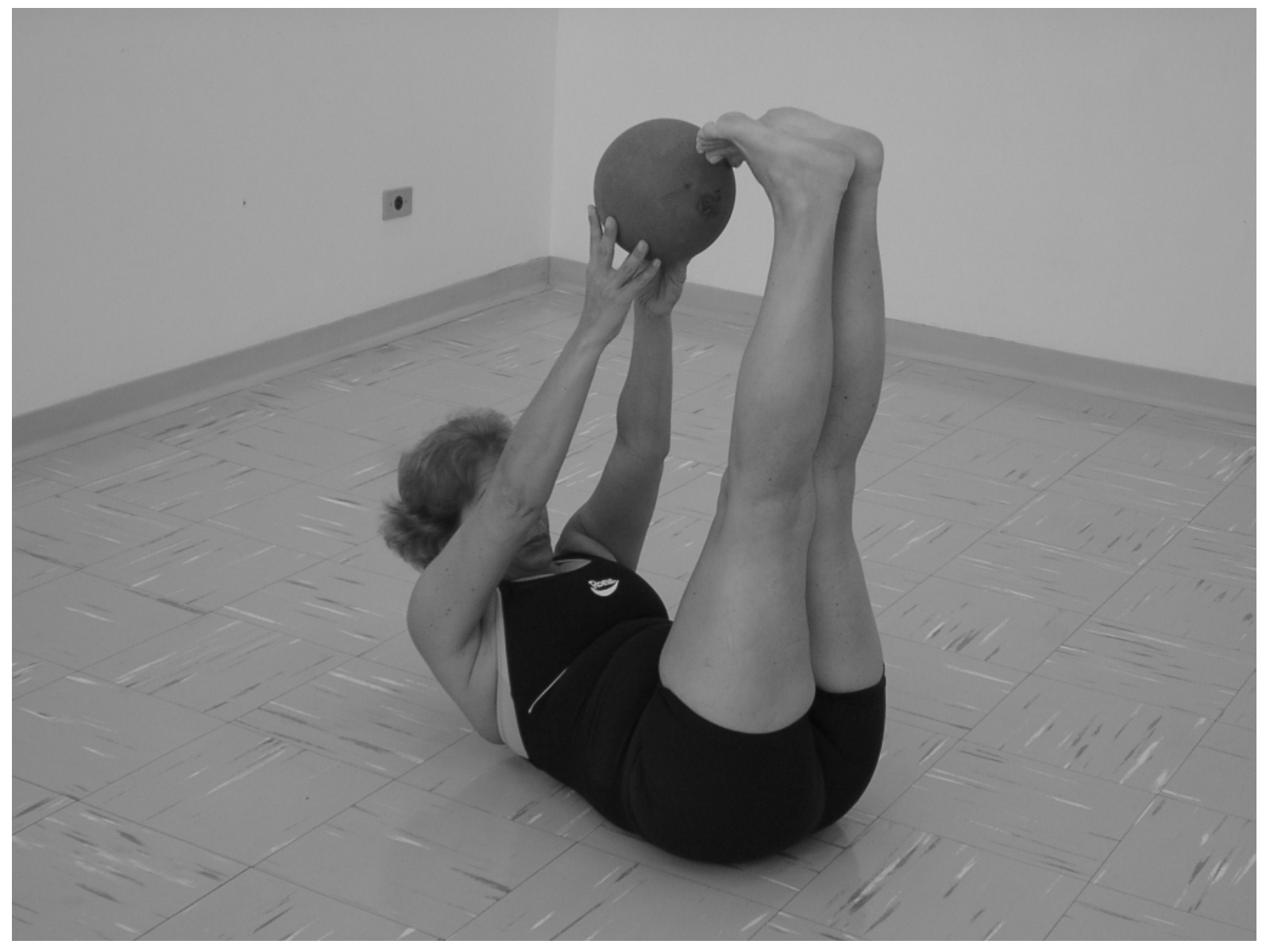




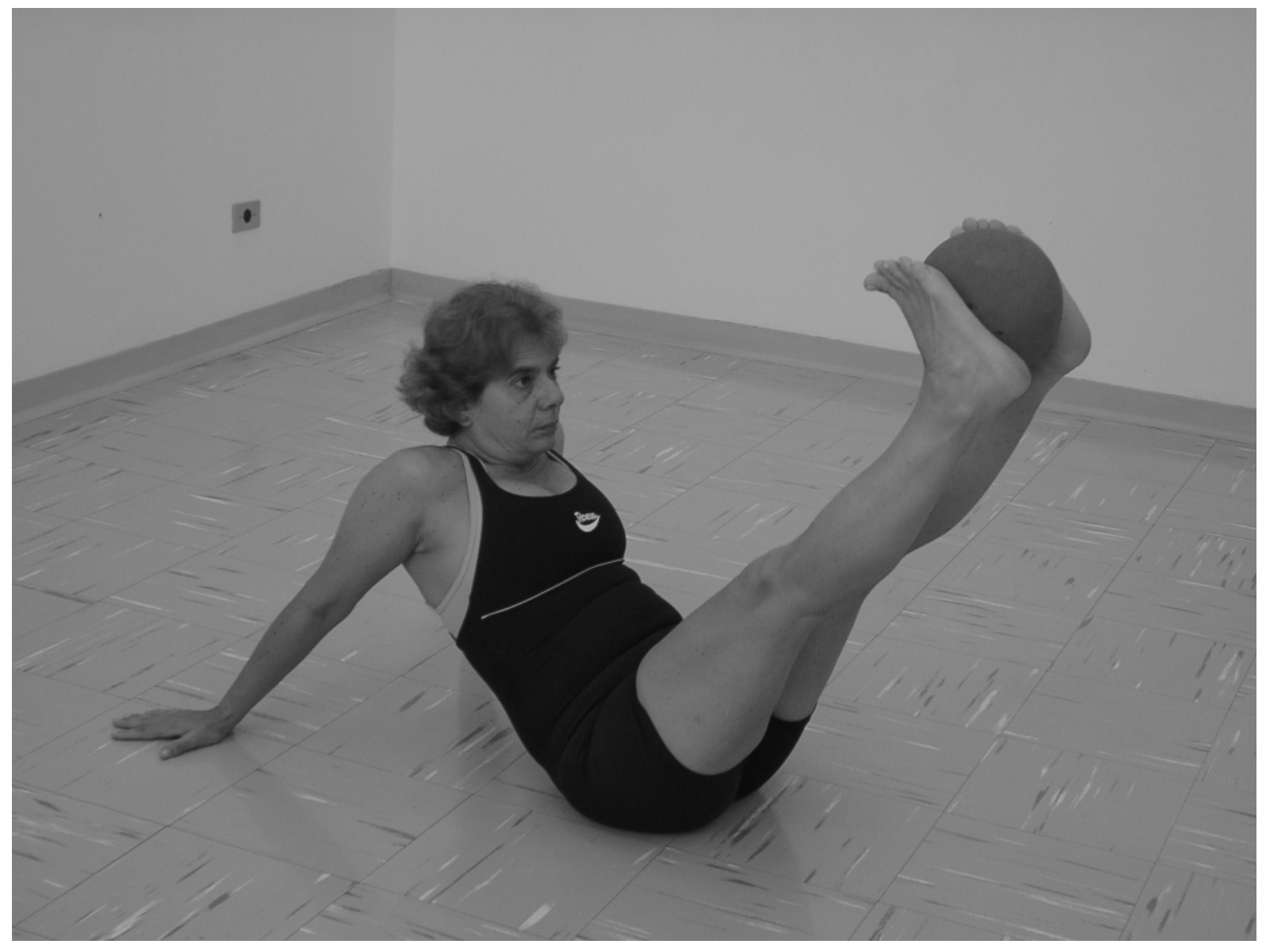




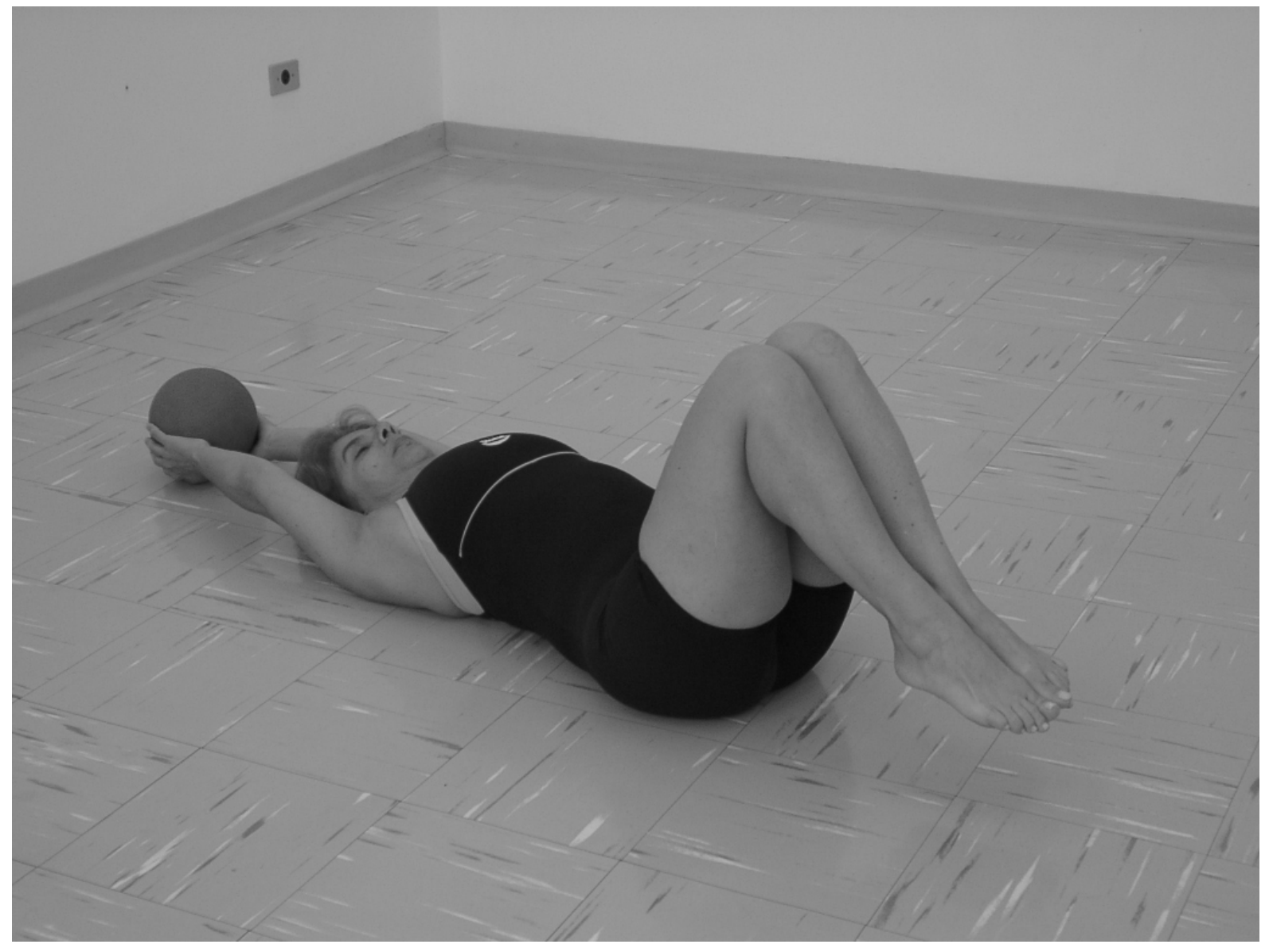




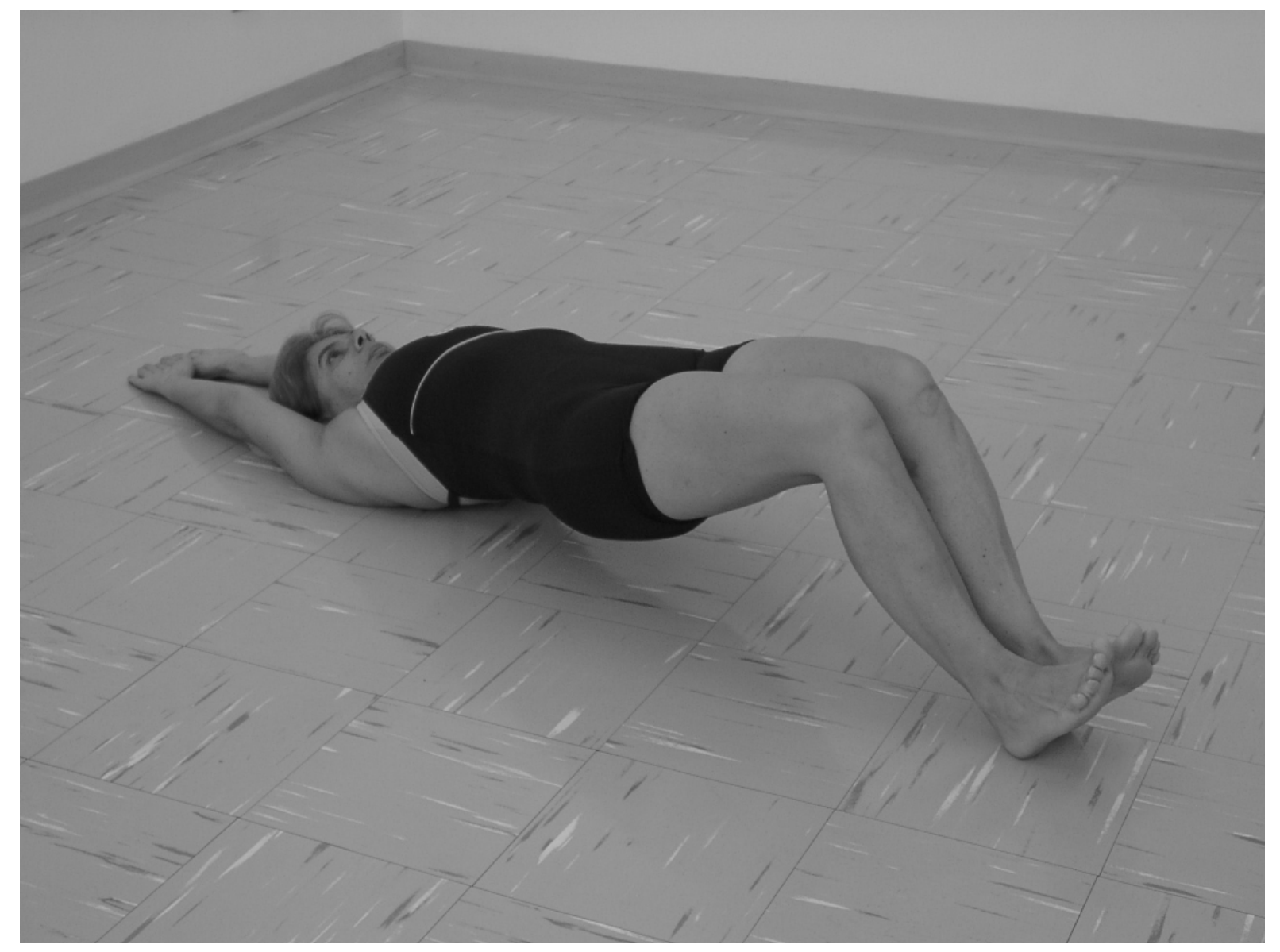




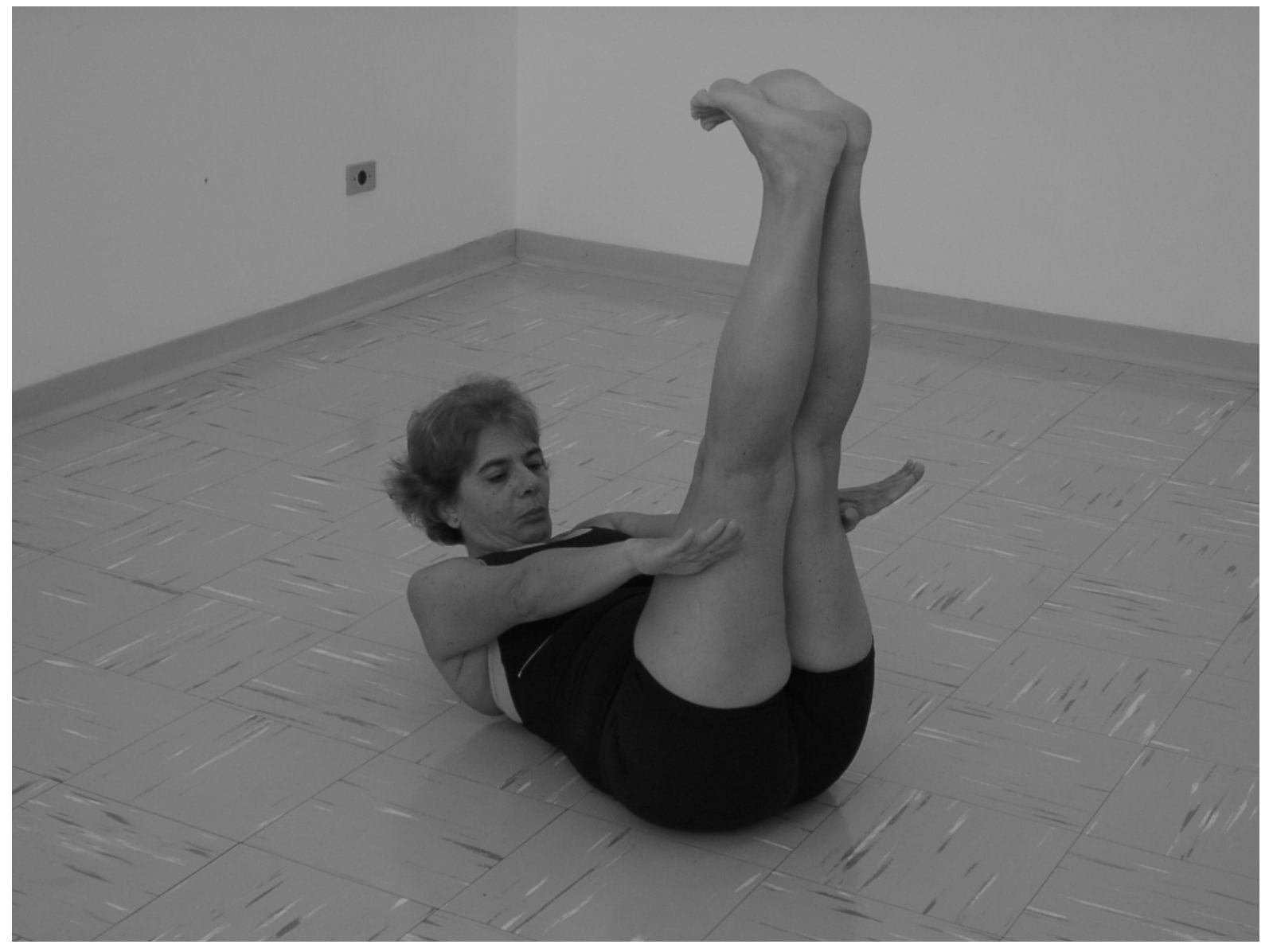




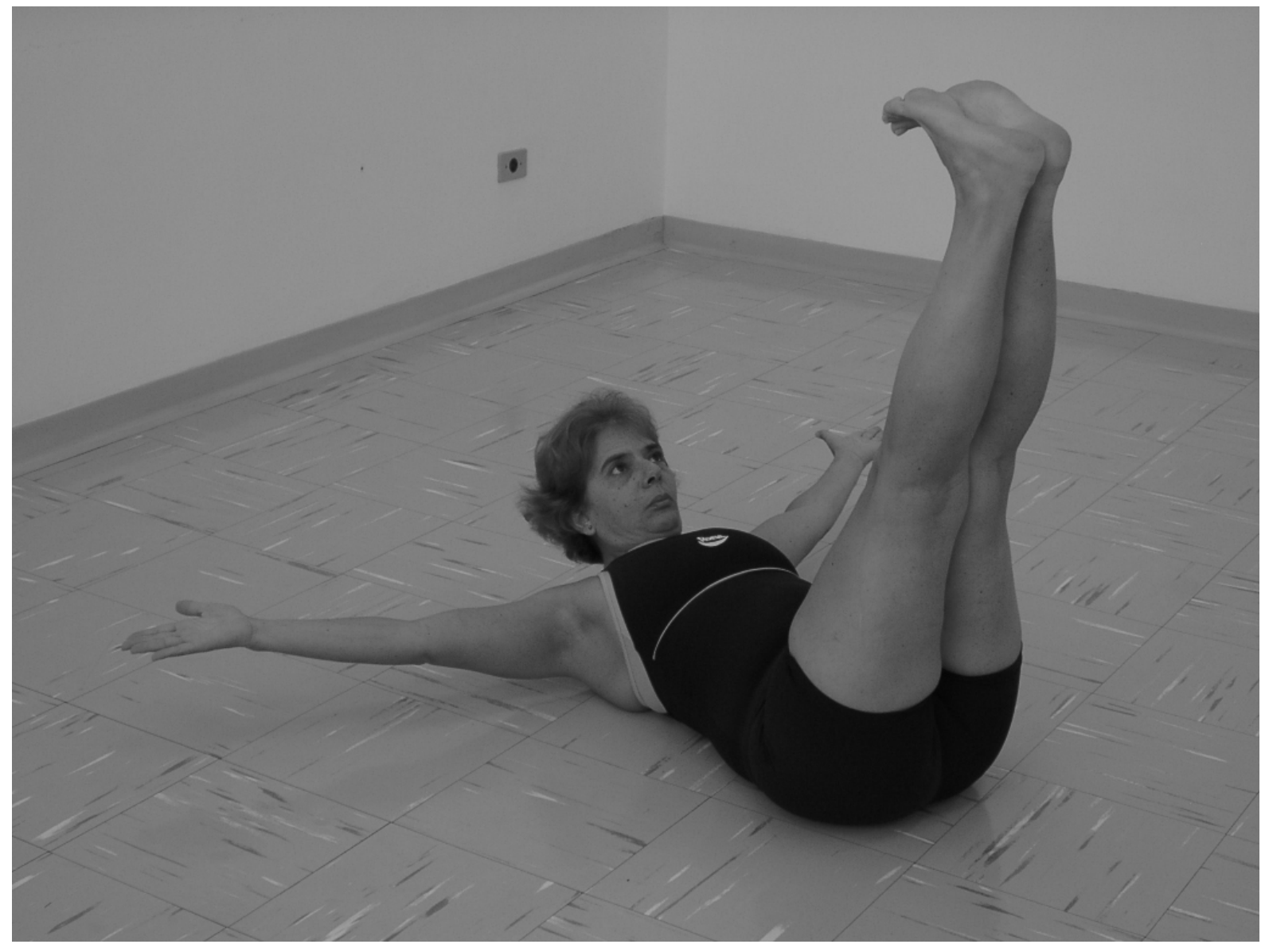




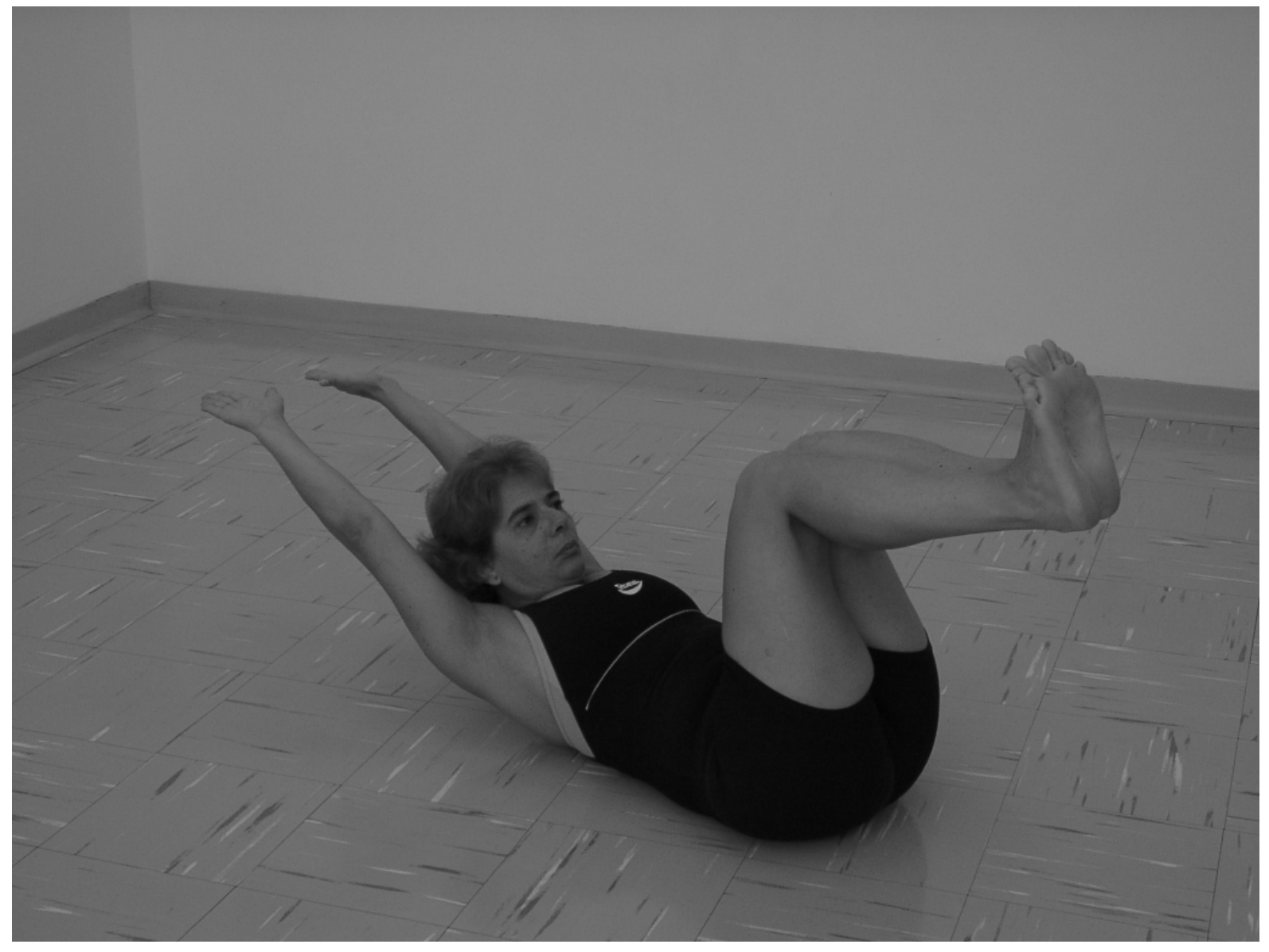




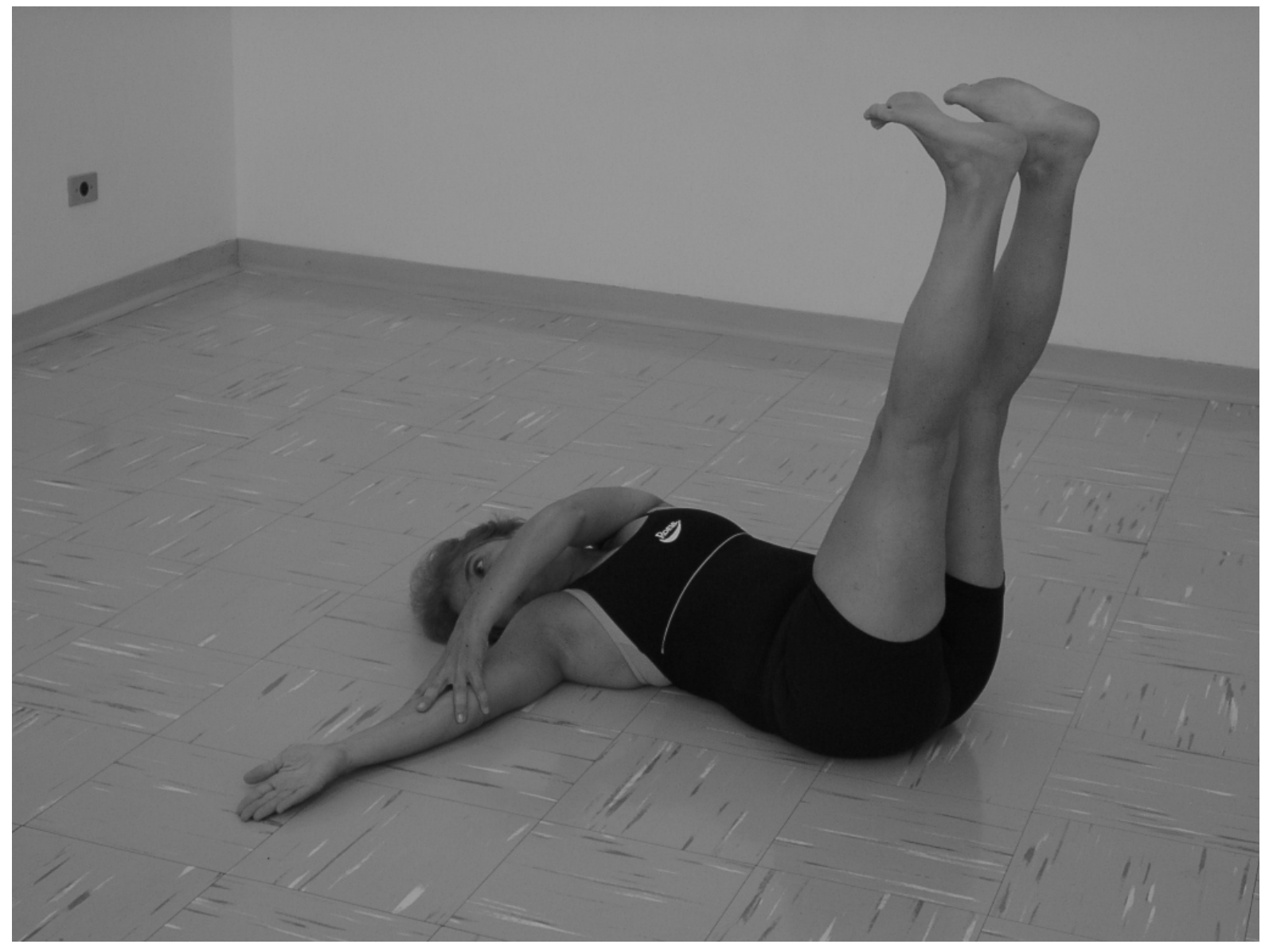




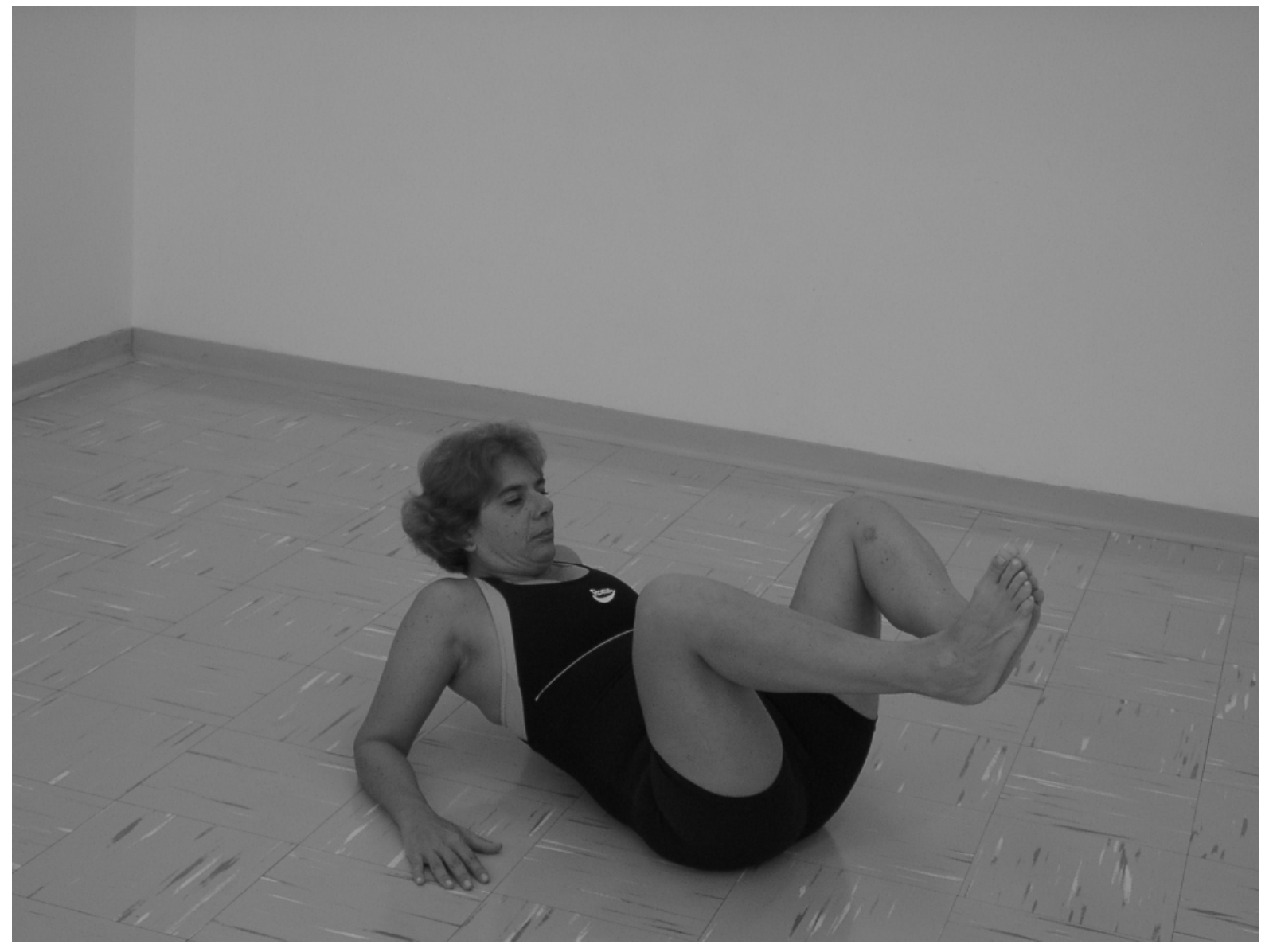




\section{DÉCIMA SEGUNDA SEMANA}




$$
5
$$




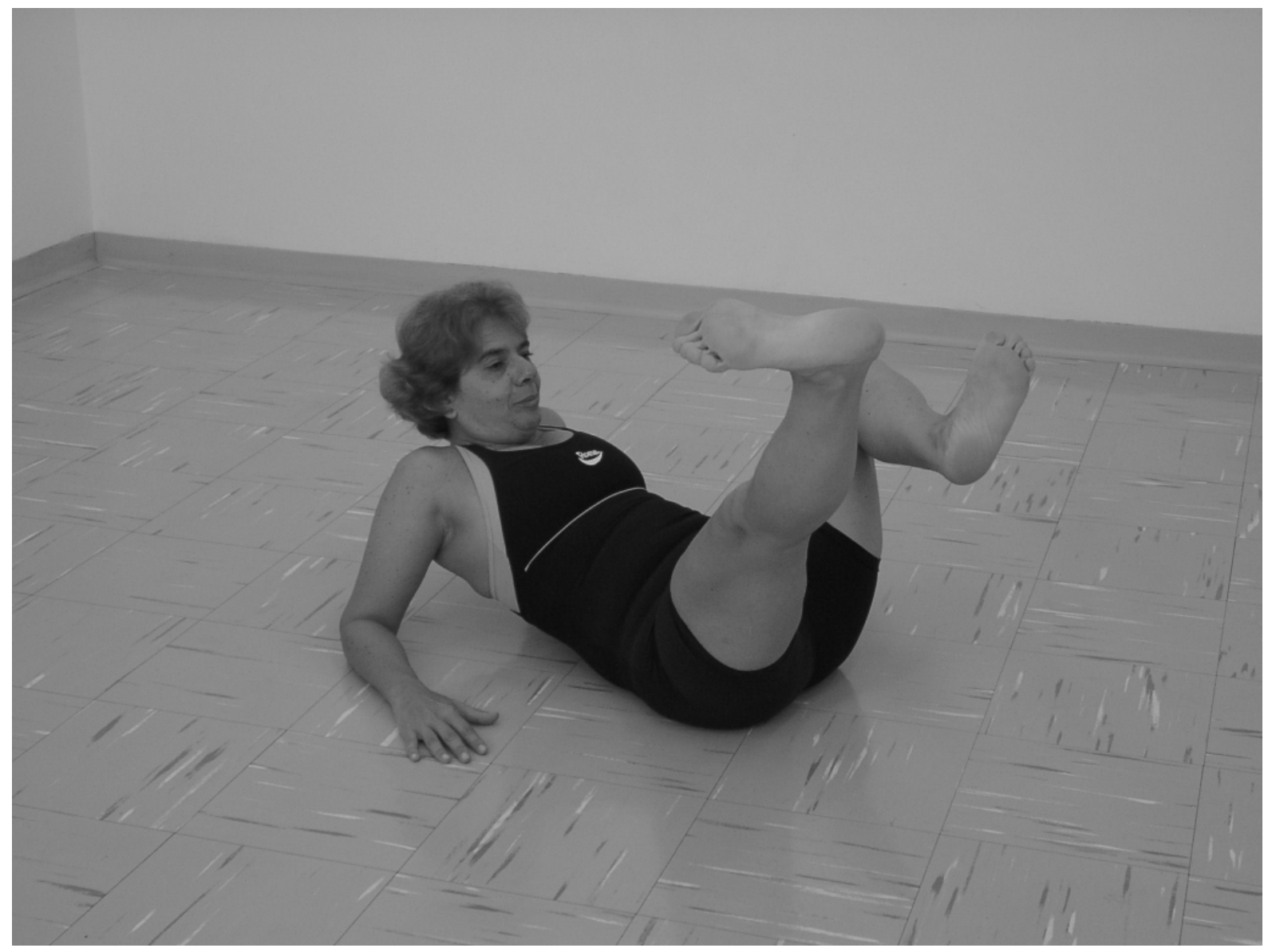




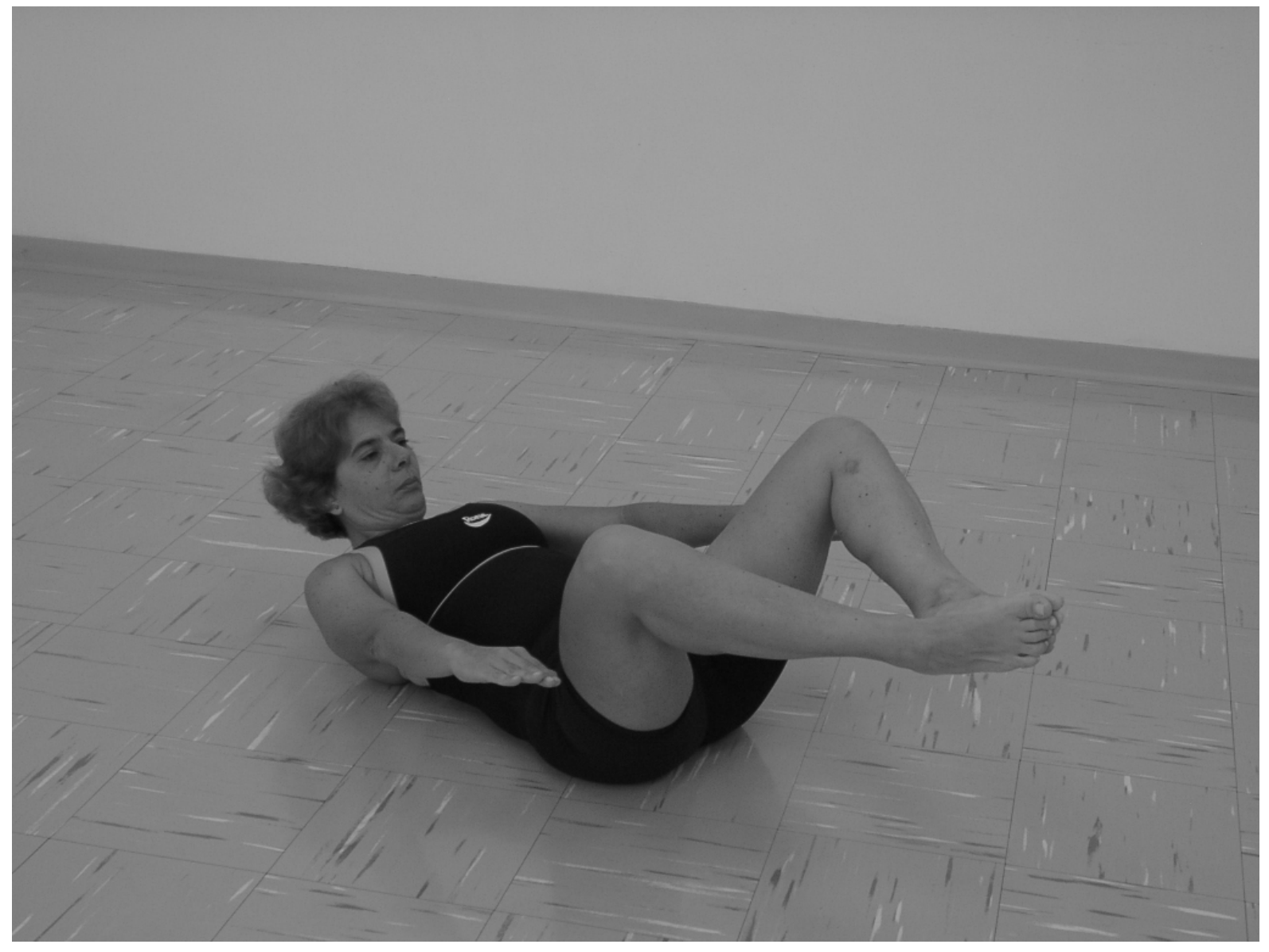




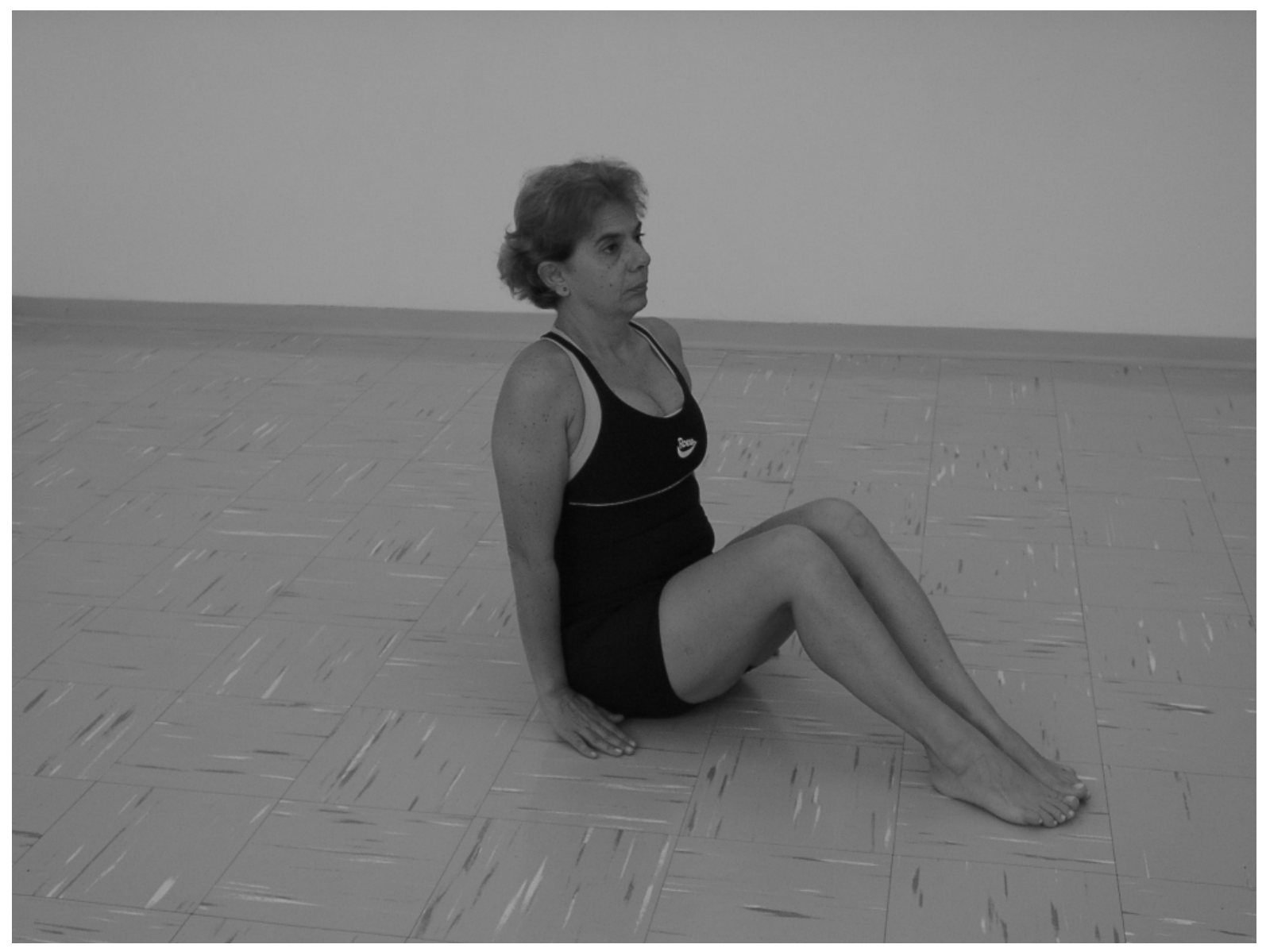




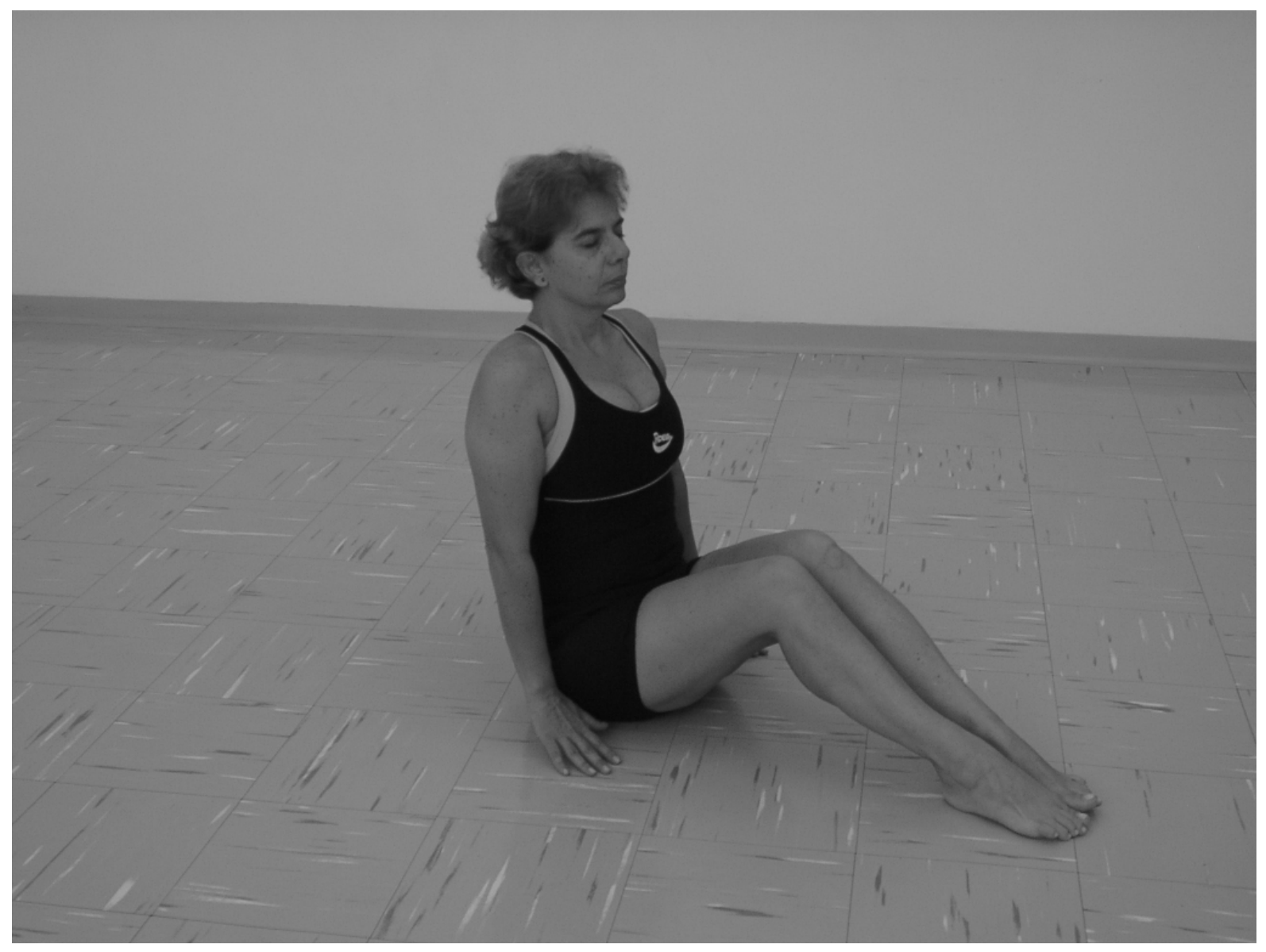




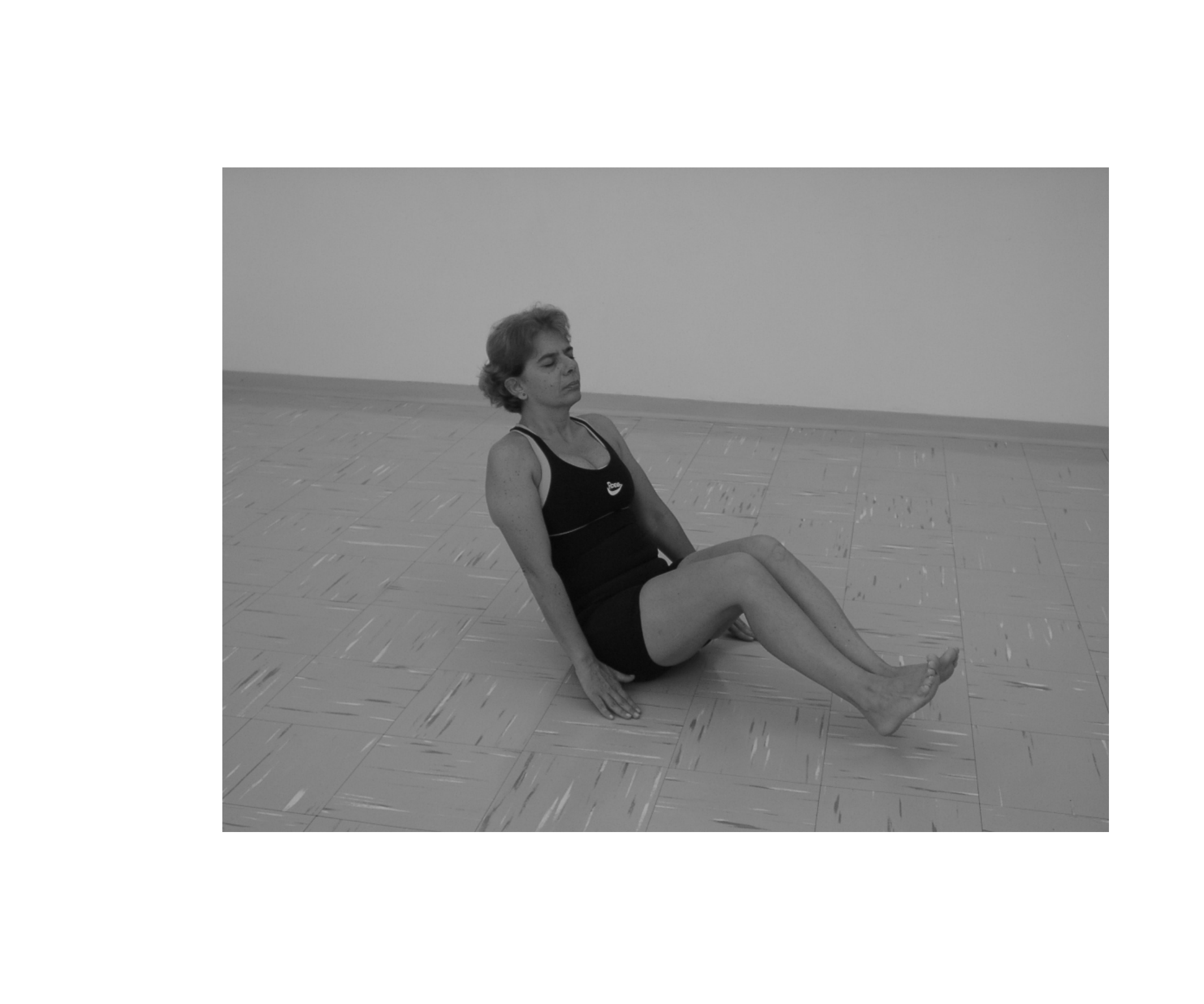




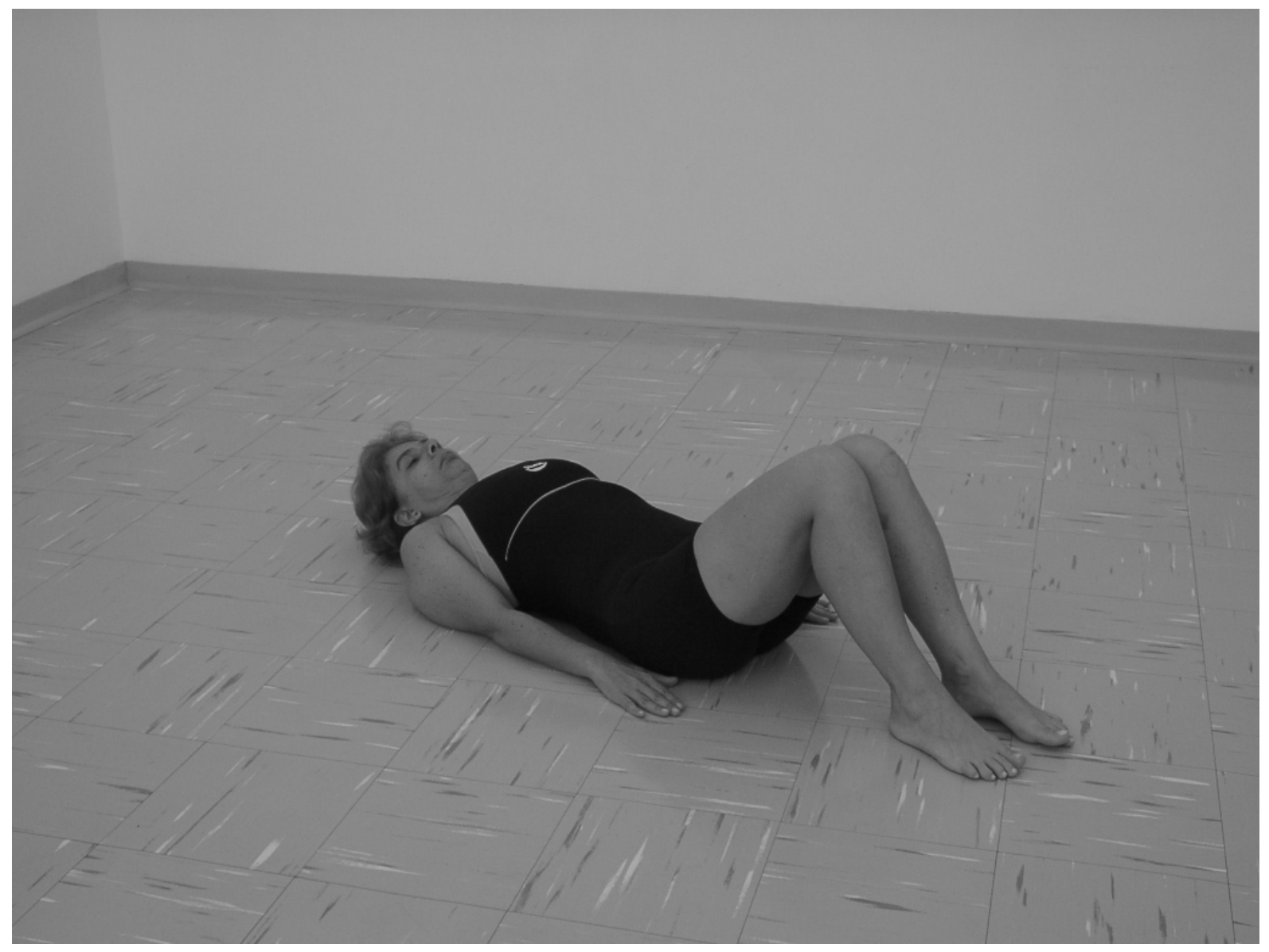




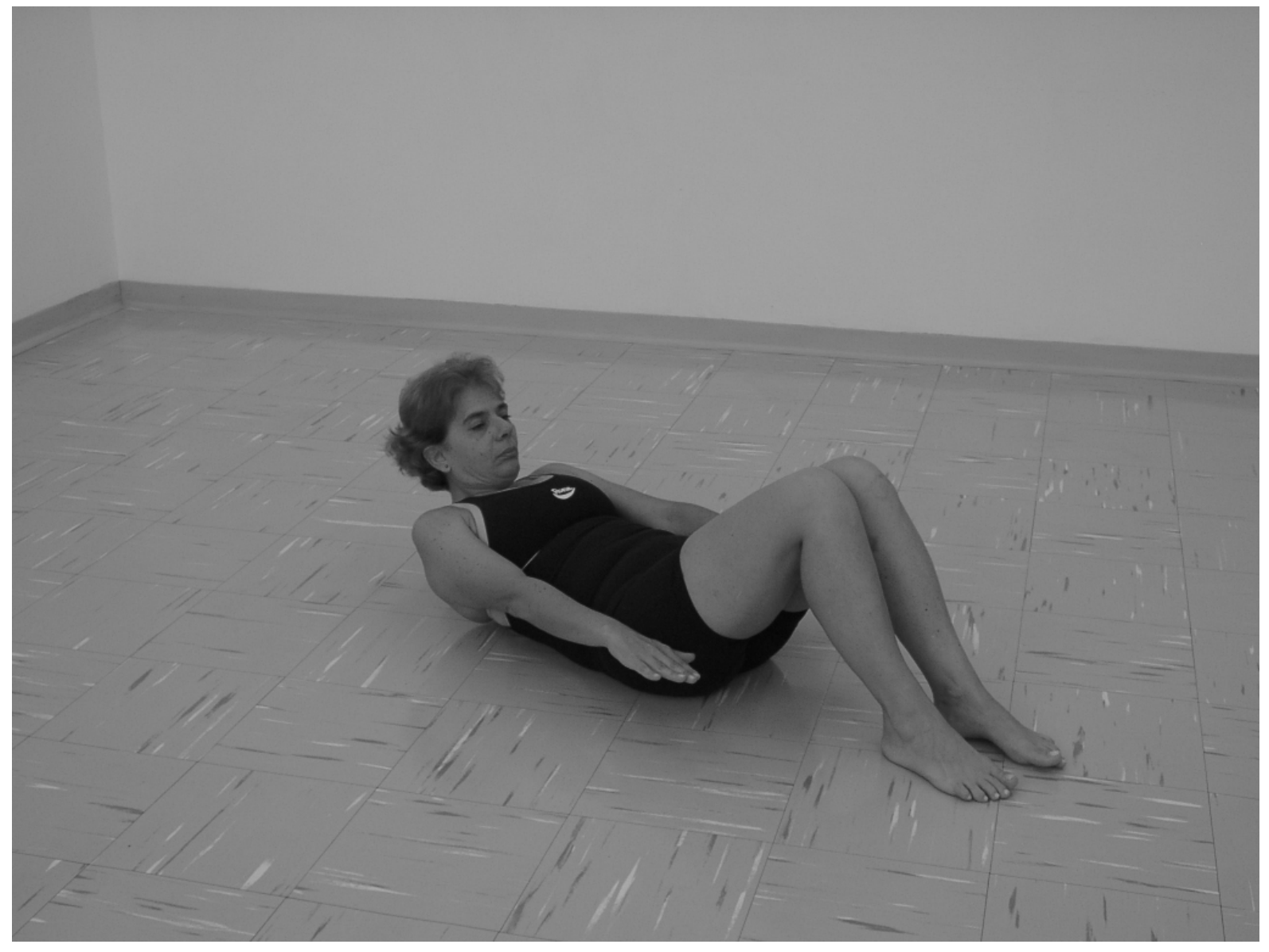




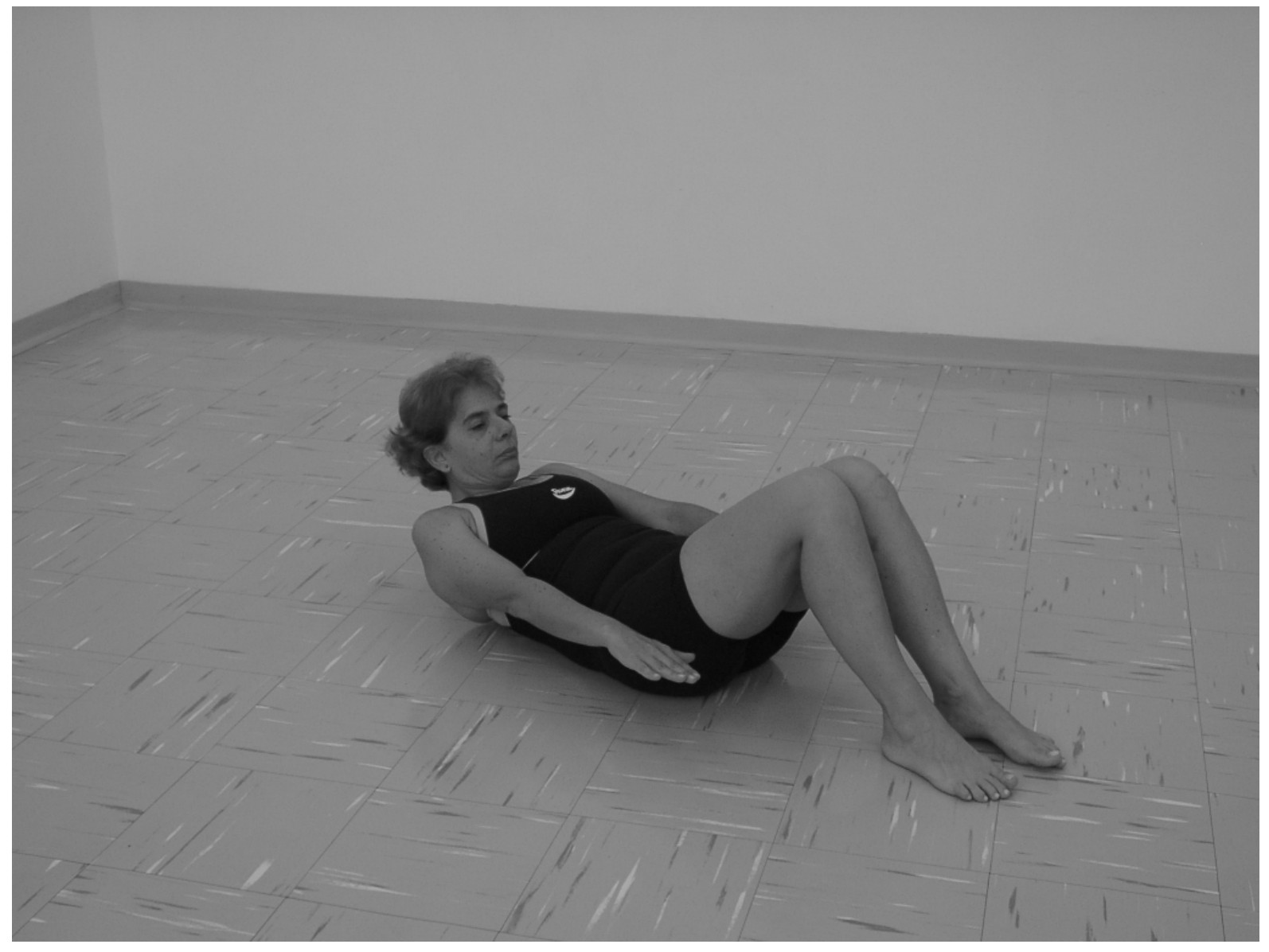




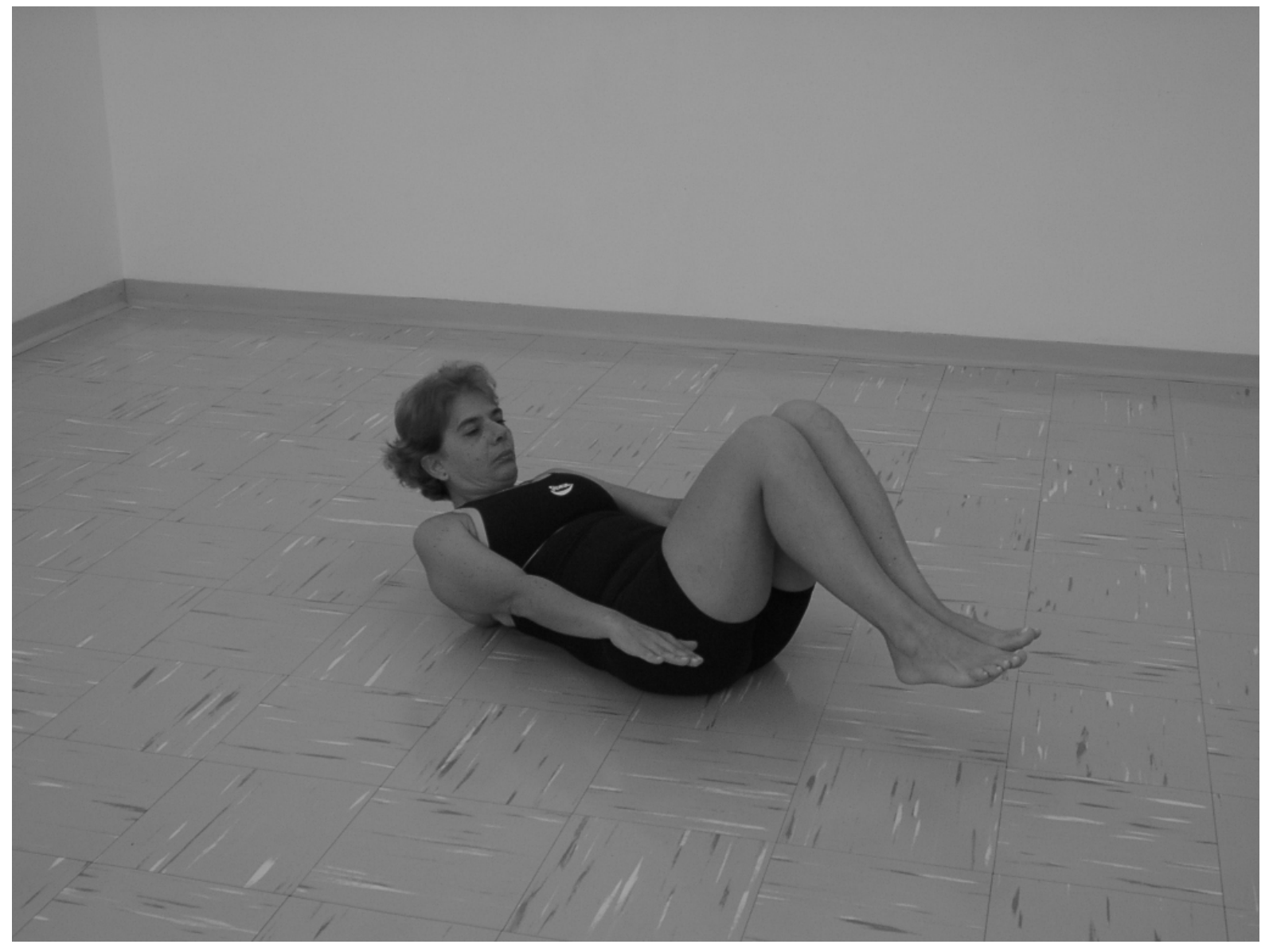




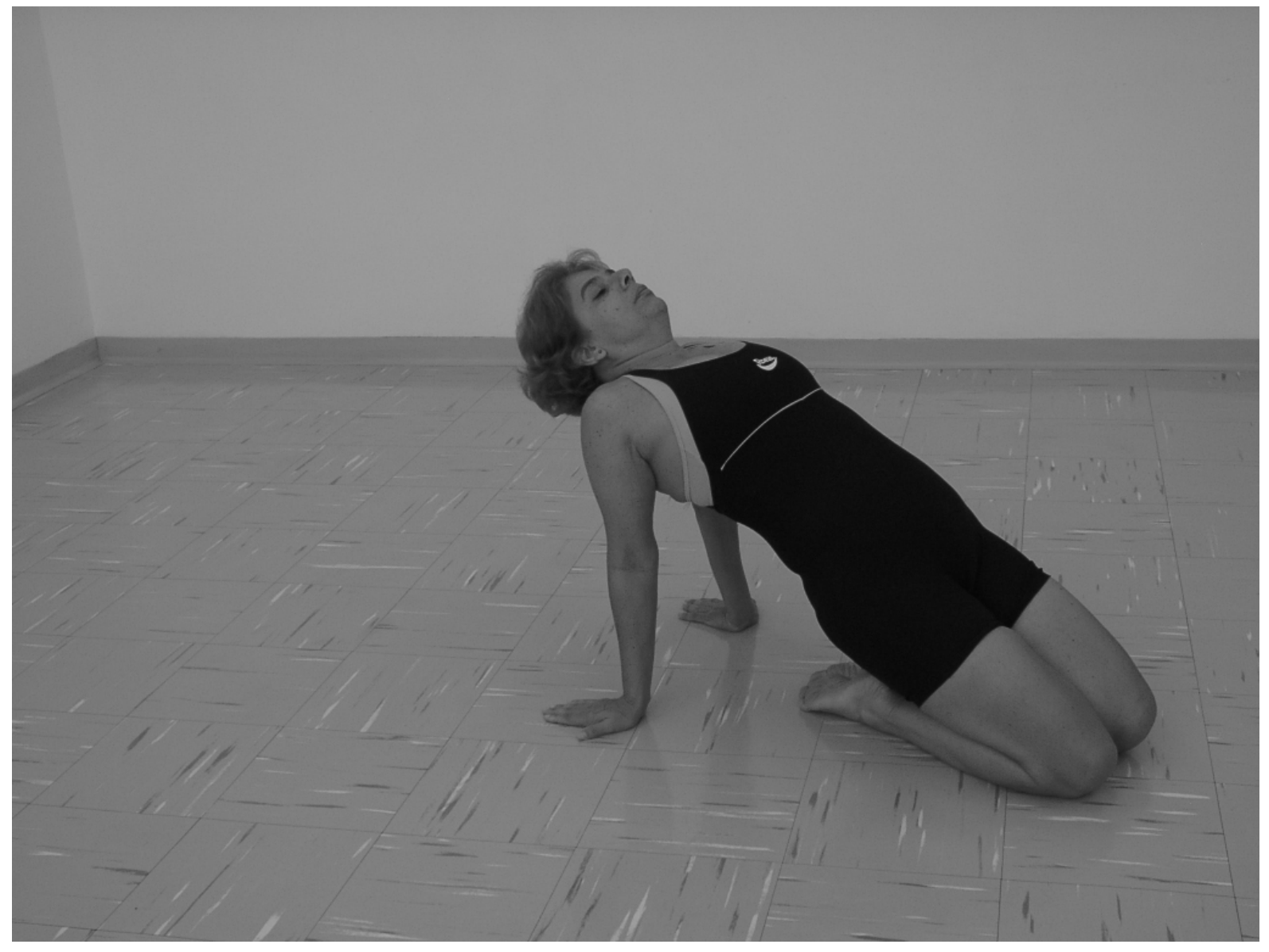




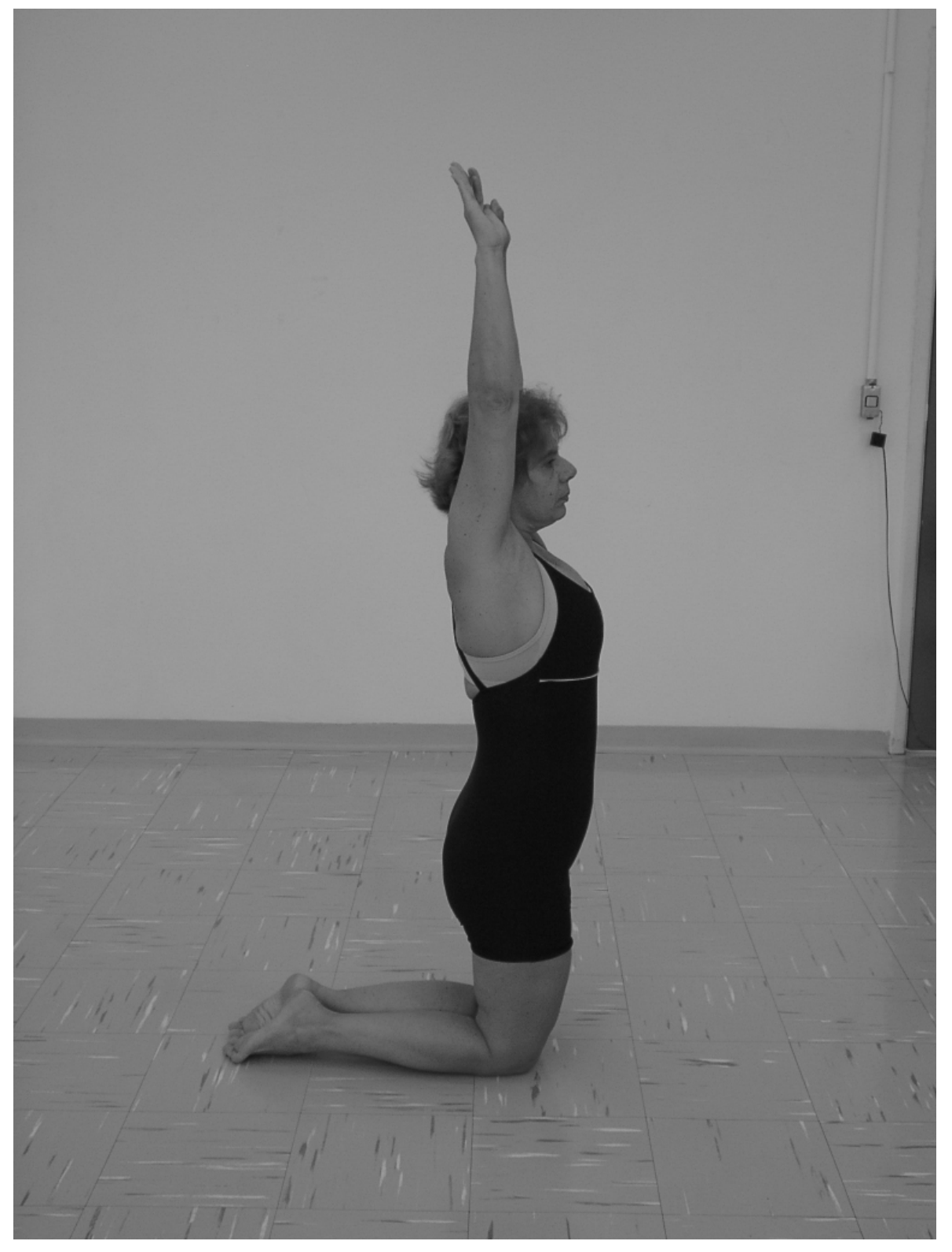




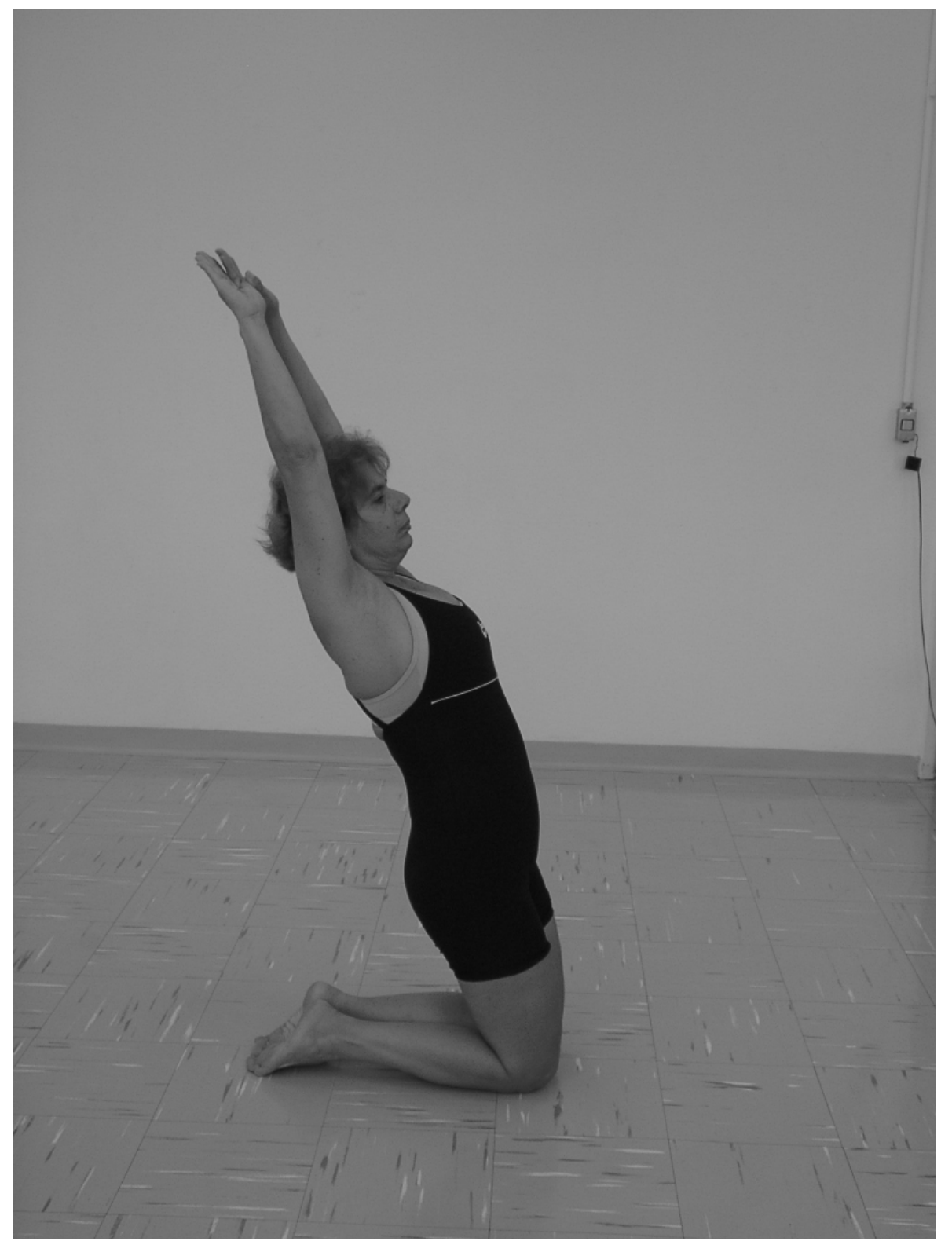




$$
1
$$

